\title{
Deindustrialization and the decline of community in the coalfields: McDowell County, West Virginia, 1950--2000
}

\author{
Mark S. Myers \\ West Virginia University
}

Follow this and additional works at: https://researchrepository.wvu.edu/etd

\section{Recommended Citation}

Myers, Mark S., "Deindustrialization and the decline of community in the coalfields: McDowell County, West Virginia, 1950--2000" (2008). Graduate Theses, Dissertations, and Problem Reports. 2741.

https://researchrepository.wvu.edu/etd/2741

This Dissertation is protected by copyright and/or related rights. It has been brought to you by the The Research Repository @ WVU with permission from the rights-holder(s). You are free to use this Dissertation in any way that is permitted by the copyright and related rights legislation that applies to your use. For other uses you must obtain permission from the rights-holder(s) directly, unless additional rights are indicated by a Creative Commons license in the record and/ or on the work itself. This Dissertation has been accepted for inclusion in WVU Graduate Theses, Dissertations, and Problem Reports collection by an authorized administrator of The Research Repository @ WVU.

For more information, please contact researchrepository@mail.wvu.edu. 
Deindustrialization and the Decline of Community in the Coalfields:

McDowell County, West Virginia, 1950-2000

\title{
Mark S. Myers
}

\author{
Dissertation submitted to the \\ Eberly College of Arts and Sciences \\ at West Virginia University \\ in partial fulfillment of the requirements \\ for the degree of
}

Doctor of Philosophy

in

History

\author{
Ronald L. Lewis, Ph.D., Chair \\ Elizabeth Fones-Wolf, Ph.D. \\ Ken Fones-Wolf, Ph.D. \\ Joe Super, Ph.D. \\ Marie Tedesco, Ph.D.
}

Department of History

Morgantown, West Virginia
2008

Keywords: coal, deindustrialization, community, McDowell, West Virginia, migration, poverty, economy, New Deal, United Mine Workers

Copyright@ 2008 Mark S. Myers 


\title{
Abstract \\ Deindustrialization and the Decline of Community in the Coalfields: McDowell County, West Virginia, 1950-2000
}

\author{
Mark S. Myers
}

During the late nineteenth and early twentieth century, the coal industry entered McDowell County, a predominantly rural county in southern West Virginia. Because of common experiences working and living in the coalfields, workers of significantly different backgrounds created a unique, working-class community in McDowell County. Although the coal industry experienced numerous downturns during the first half of the twentieth century, there was a long-term rise in the number of workers employed by the industry. By 1950, McDowell County had a population of almost 100,000, most of which was impacted by the coal industry.

After World War II, however, the industry began to change. Competition from alternative fuels, such as oil, natural gas, and nuclear power, forced coal companies to cut costs in order to survive in a tight market. Companies first tried mechanization to cut labor costs, a phenomenon that had roots well before the post-war period. For those companies that could not, or would not, implement machinery, the only true alternative was to close the mines.

I argue that deindustrialization, the combination of mechanization and disinvestment in McDowell County, contributed to the loss of the unique coalfield community that flourished in the county during much of the twentieth century. This occurred in two ways. First, many former miners left the county in an attempt to find work; most migrated either to the Midwest or to Maryland. Second, those who remained found a county much different than before. The lack of diversification in the county's economy limited the employment prospects of the people remaining, leading to a significant increase in poverty. The decline in coal employment and the increase in poverty created a society of contrasts, where some residents succeeded, while many more struggled to survive. 
For Heather. 


\section{Acknowledgements}

A project such as this is never a purely individual endeavor. I would like to thank Dr. Ron Lewis for his guidance throughout this process. I would also like to thank my committee members, Dr. Elizabeth Fones-Wolf, Dr. Ken Fones-Wolf, Dr. Joe Super, and Dr. Marie Tedesco, for their assistance and encouragement. The staffs at the Eastern Regional Coal Archives in Bluefield, West Virginia and the West Virginia Regional History Collection at West Virginia University provided invaluable services to me over the years. Finally, my wife Heather supported me throughout the writing and revising of the manuscript. She helped in the editing process and encouraged me to push ahead. Without her, this would not have been possible. 


\section{Table of Contents}

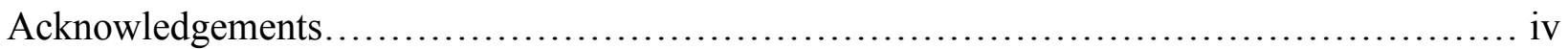

Table of Contents.....................................................................

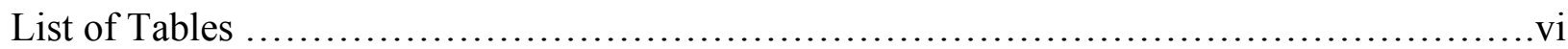

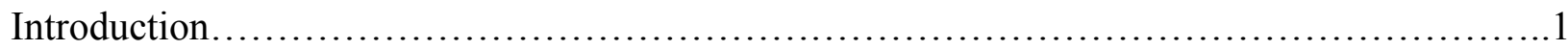

Chapter 1. The Birth of King Coal: The Development of a Coalfield Community..............31

Chapter 2. Depression, Recovery, Instability: The New Deal and McDowell Coal.............57

Chapter 3. Deindustrialization and the Economics of Coal..............................82

Chapter 4. "American Standards?" The Union and Deindustrialization.......................121

Chapter 5. You Can't Go Home Again: Out-migration from McDowell County.............161

Chapter 6. A World of Contrasts: McDowell After Deindustrialization.......................195

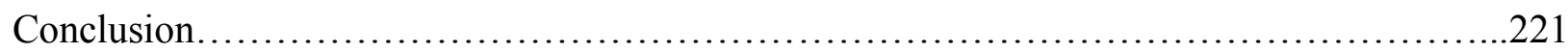

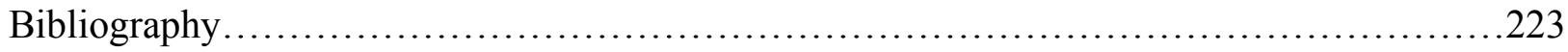




\section{List of Tables}

1. Production and Machinery in Selected McDowell County Coal Mines, 1940..........101

2. Production and Machinery in Selected McDowell County Coal Mines, 1945..........104

3. Employment in Selected McDowell County Coal Mines, 1940 and 1945.............107

4. Production and Machinery in Selected McDowell County Coal Mines, 1950..........108

5. Employment in Selected McDowell County Coal Mines, $1950 \ldots \ldots \ldots \ldots \ldots \ldots \ldots \ldots . . . . . . .110$

6. West Virginia Coal Production and Employment, by Method of Mining, 1951-1955...112

7. Production and Employment at Selected McDowell County Coal Mines, 1955 and

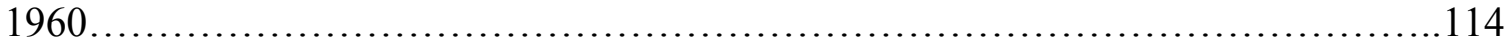




\section{Introduction}

For many years, Central Appalachia has been synonymous with extreme poverty and want. From the 1960s television special, Christmas in Appalachia, to popular works by numerous authors, the American perception of the Appalachian region is primarily one of a poor, backward region that is behind the times. The story of Central Appalachia is so much more than what is commonly perceived. The story of the region is similar to that of many other areas in the country, one of success turned to despair. The region enjoyed some economic success with the entrance of the bituminous coal industry during the latter decades of the nineteenth century and the early decades of the twentieth century. Because of the nature of industrialization in the coalfields, the people who worked in the mines developed a unique sense of community centered around common experiences in the mines and coal towns of the region. The coal industry, however, was - and is - a very unstable one, characterized by boom-andbust cycles. Although there were periods of great prosperity throughout the region, there were also years of want and strife. By the middle of the twentieth century, the coal industry had begun a process of reorganization through mechanization and consolidation. As a result, many miners found themselves out of work, as companies either implemented the new, more productive, machines or simply closed the mines. Poverty, which had been a problem in Appalachia due to the dependence on the unstable coal industry, exploded as a result of the reorganization of the mines. Because of the economic problems of the region, people lost the sense of community that characterized the coalfields for so many years. 
McDowell County, West Virginia, lies in the heart of Central Appalachia. The southernmost county in the state, McDowell was built by the people working in the coal industry. McDowell holds an important place in the history of coal because, for many years, the county was the leading coal producer in the country. Thousands mined the coal and lived in the county; by 1950 McDowell's population reached nearly 100,000 . How, then, did the population decline by more than 70,000 in fifty years? Why did many of the people who remained in the county suffer from a low standard of living? What has been the effect of the socioeconomic changes on the people of the county and their community? By examining these questions, one can not only gain an understanding of the history of one locale, but also the socioeconomic history of an entire region.

The experience of McDowell County, and the coal industry as a whole, was not a purely regional phenomenon. Starting in the 1970s, the American economy underwent a profound and important transformation. Throughout the Midwest, for example, industrial plants and mills closed one after another through a process known as deindustrialization. The costs of deindustrialization were widespread. Not only were whole communities destroyed, the economy was largely unable to provide workers with a standard of living comparable to that enjoyed in the 1950s and 1960s. To understand fully this process, and the similarities and differences between deindustrialization in the nation and that of the Appalachian coalfields, several questions must be considered. ${ }^{1}$ What was the general process and national trend of

\footnotetext{
${ }^{1}$ Although it seems that what occurred in Central Appalachia is more of a case of industrial restructuring, I argue that deindustrialization is a more apt descriptor for the phenomenon because of the impact the
} 
deindustrialization in the United States? How does the experience of McDowell fit into this broader context? What were some of the economic difficulties facing the coal industry in the post-World War II era? How did coal mechanization influence deindustrialization in the coalfields? ${ }^{2}$

In their highly influential book, The Deindustrialization of America, Barry Bluestone and Bennett Harrison define deindustrialization as "a widespread, systematic disinvestment in the nation's basic productive capacity."3 In depicting deindustrialization as a struggle between communities and capital, Bluestone and Harrison argue that corporations divert funds from the nation's basic industries into speculation, mergers, and foreign investment. For example, U.S. Steel paid \$6 billion to acquire Marathon Oil, instead of investing in its steel operations. Therefore, instead of rebuilding its steel capacity, U.S. Steel chose to focus on acquisitions, furthering the deindustrialization process. ${ }^{4}$

There have been several ways in which corporations have shifted capital from one place to another. First, companies shift profits from one plant's operation to another part of the corporation, usually to upgrade the facilities or for new product development. Second, companies may simply fail to replace obsolete machinery. As a result, plants eventually fail to generate enough profits and face closure. The third industrial restructuring had on the people of the region. See: Jefferson Cowie, Capital Moves: RCA's Seventy Year Quest for Cheap Labor (Ithaca, NY: Cornell University Press, 1999).

${ }^{2}$ Bluestone, Barry and Bennett Harrison, The Deindustrialization of America: Plant Closings, Community Abandonment, and the Dismantling of Basic Industry (New York: Basic Books, 1982), 4; Stephen High, Industrial Sunset: The Making of North America's Rust Belt, 1969-1984 (Toronto: University of Toronto Press, 2003), 4.

${ }^{3}$ Bluestone and Harrison, The Deindustrialization of America, 6.

${ }^{4}$ Ibid.; Wall Street Journal, 5 February 1982; High, Industrial Sunset, 4. 
method of shifting capital is to relocate machinery from one location to another. As a result, the plants continued to operate, but at a much lower rate of production. Fourth, management can shift capital by closing an entire plant. Often, companies may move the entire operation to another area where costs may not be as high. ${ }^{5}$

There are several explanations of the meaning of deindustrialization. At the core of each theory is conflict. For example, David Bell, in his work The Coming of the Post-Industrial Society, argued that the changes taking place in industry were indicative of a new post-industrial economy characterized by computers, telecommunications, and technology. ${ }^{6}$ Rather than being an example of the changing economy over which humans have little influence, proponents of the deindustrialization thesis, including Bluestone and Harrison, depict the changes as the result of conscious decisions made by managers. While Bluestone and Harrison see deindustrialization as a conflict between communities and companies, Robert Laxer (who first suggested the deindustrialization thesis in 1973) argued that patriotism was the root cause of deindustrialization. According to Laxer and other Canadian economic nationalists, American-based corporations closed Canadian plants and relocated operations to the United States in order to protect jobs south of the border. Despite the differences between the different versions of the deindustrialization thesis, one important similarity remains, the loss of control. For Laxer and the Canadian nationalists, deindustrialization is characterized by the loss of national control over the economy.

\footnotetext{
${ }^{5}$ Bluestone and Harrison, The Deindustrialization of America, 7.

${ }^{6}$ Daniel Bell, The Coming of Post-Industrial Society: A Venture in Social Forecasting (New York: Basic Books, 1973); High, Industrial Sunset, 7.
} 
For American deindustrialization theorists, the loss of local control over the economic lives of the people of the community is the most important characteristic of the process of industrial change. In a sense, both versions of the theory have the same antagonist, managers of corporations who make conscious business decisions to shift capital and employment elsewhere. ${ }^{7}$

Although the deindustrialization thesis is influential because of the focus on the decimation of communities, there are many who see disinvestment as a minor problem or no problem at all. The belief that deindustrialization was a minor issue nationally resulted from a narrow definition of the situation. If deindustrialization is defined as occurring only when a plant completely shuts down and relocates elsewhere, then it is not much of a problem. For example, approximately 2 percent of employment change between 1969 and 1976 resulted from plant closures. ${ }^{8}$

Some scholars believe disinvestment is crucial in order to improve the productivity of the American economy. Lester Thurow, for example, argues that it is in the best interests of the American economy to shift capital and labor from old areas of low productivity to areas where higher productivity can be reached. He argues that the American economy is extremely unsuccessful at disinvestment because of the political pressure that results from unpopular decisions to close plants. Thurow argues that the

\footnotetext{
${ }^{7}$ Robert M. Laxer, ed., (Canada) Ltd. The Political Economy of Dependency (Toronto: McClelland and Steward, 1973), 9, 146; High, Industrial Sunset, 7-8.

${ }^{8}$ David L. Birch, The Job Generation Process (Cambridge, MA: MIT Program on Neighborhood and Regional Change, 1979); Bluestone and Harrison, The Deindustrialization of America, 8.
} 
slow rate of deindustrialization hinders America's opportunity to compete effectively in the international marketplace. ${ }^{9}$

Thurow's theory is a derivative of Joseph Schumpeter's writings from the 1940s. Schumpeter argues that capitalist economies can only improve prosperity by going through a process of "Creative Destruction."10 In other words, to stay healthy, an economy must destroy and then regenerate itself. Without change, an economy will not have the strength to move forward and eventually will decline. As a result, deindustrialization must occur in order to foster growth elsewhere. ${ }^{11}$

Although the disinvestment theory makes sense if one considers only the 2 percent of unemployment that results from the closing of plants and mills, the theory does not stand up to deeper scrutiny. Bluestone and Harrison find that job loss is a serious problem. If one takes into account all the ways that deindustrialization can occur, then it becomes clear that private disinvestment cost Americans between 32 and 38 million jobs during the 1970s. Established plants faced a 30 percent chance of closure and only two out of every five smaller firms survived the decade. ${ }^{12}$

If deindustrialization existed only in the abstract, theoretical realm, then any discussion of the phenomenon would be purely academic. However, there is a more realistic side to disinvestment. Throughout the United States, there are serious personal

\footnotetext{
${ }^{9}$ Lester Thurow, The Zero-Sum Society (New York: Basic Books, 1980), 77; Bluestone and Harrison, The Deindustrialization of America, 8.

${ }^{10}$ Joseph Schumpeter, Capitalism, Socialism, and Democracy (New York: Harper and Row, 1942), 83; Bluestone and Harrison, The Deindustrialization of America, 9; High, Industrial Sunset, 7.

${ }^{11}$ Ibid.

${ }^{12}$ Bluestone and Harrison, The Deindustrialization of America, 9.
} 
and social losses that result from deindustrialization. According to Schumpeter's theory of creative destruction, deindustrialization will enable capital and labor to become more productive by closing unproductive businesses. In most instances, however, this is not the case. Most studies of unemployment find that many displaced workers find it difficult to get a job comparable to the one they lost. As a result, the standard of living for millions of Americans has been negatively impacted by disinvestment. A decreased standard of living is not the only personal cost of deindustrialization. Workers suffer serious mental health problems when plants are suddenly closed. Communities and local governments also take in less revenue through sales and business taxes. As a result, there are fewer available funds for such local essentials as police and fire service, improved infrastructure, and education. Quality of life declines as well because there is less available money for parks and other recreational activities. $^{13}$

Many of the problems discussed within the literature on deindustrialization occurred within Central Appalachia. Deindustrialization in Central Appalachia led to many changes in the region. Because of the socioeconomic changes within the region, many Appalachians decided to migrate out of the region in search of work. What about those who stayed behind? What did the economic changes mean for them? For many within the region, failure to leave, for whatever reason, resulted in an increase in endemic poverty, as folks found it difficult to find work. This situation affected the people of McDowell County. With a significant decline in the number of coal mining

\footnotetext{
${ }^{13}$ Ibid., 10-11; Louis S. Jacobson, "Earnings Losses of Workers Displaced from Manufacturing Industries," in William G. Dewald, ed., U.S. Department of Labor, The Impact of International Trade and Investment on Employment (Washington: U.S. Government Printing Office, 1978).
} 
jobs available in the county, many people failed to find adequate work in order to maintain a quality standard of living. With few exceptions, the years since 1950 have been characterized by intense poverty in many areas of McDowell County. This is a story of contrast, however. While national media usually focus on the poorest of the poor in stories on the region, there were many people in McDowell County, and in the region as a whole, who succeeded during the changing times. The people who succeeded primarily were miners who survived the job cuts of the 1950s and 1960s, folks who returned to the mines during the boom years of the 1970s, or collegeeducated residents who found work in service jobs, primarily as teachers or government workers.

Despite the few examples of success, the story of McDowell County after 1950, and Central Appalachia as a whole, is primarily one of suffering. After 1980, a decline in the national economy, coupled by cutbacks in national welfare programs, meant that the resources that so many poor people depend on were taken away. As a result, a sense of helplessness and despair has infiltrated the minds of some within the region. Despite this sense of helplessness, it would not be accurate to characterize the mindset of the entire region as one of hopelessness. Many people are trying to improve their lives and communities through economic development activities, including improving infrastructure. One of the primary reasons for the difficulties facing the region in the post-war era was the lack of economic diversity within the region. In McDowell County, the political leadership failed to appreciate the very nature of the coal industry, that the industry is characterized by boom and bust periods. Furthermore, because the industry and union came together in support of mechanization without any financial 
support for the communities and people affected by the massive number of layoffs, the political leadership of the county was in a position where only it could have limited the adverse effects of deindustrialization. ${ }^{14}$

The issue is a much more complex one than described above. The Central Appalachian coalfields proceeded through three periods of development after deindustrialization. The 1950s and 1960s were decades characterized by increased unemployment and poverty in much of the region. During the 1960s Appalachia became known within the American consciousness as an area beset with deep and endemic poverty. Nationally, the region was seen as a place that was outside the mainstream, both socially and economically. The issue was not a structural problem within the capitalist economy, but rather one of integrating Appalachia, and other poor regions, into the American economy. By the 1970s, the situation had begun to change within Central Appalachia. Because of energy concerns and other economic problems, the demand for coal increased to a point where coal employment began to recover somewhat. This period of prosperity in Central Appalachia did contrast to that of the Midwestern Rust Belt, where deindustrialization was in full swing by 1973. The prosperity was not to last, however. By the 1980s, a pattern of uneven development began to appear throughout the region. As the coal industry declined and poverty

\footnotetext{
${ }^{14}$ John Gaventa, Barbara Ellen Smith, and Alex Willingham, eds., Communities in Economic Crisis: Appalachia and the South (Philadelphia: Temple University Press, 1990), 3-4. See also: Commission on Religion in Appalachia, Economic Transformation: The Appalachian Challenge (Knoxville, TN: Commission on Religion in Appalachia, 1986); MDC Panel on Rural Economic Development, Shadows in the Sunbelt: Developing the Rural South in an Era of Economic Change (Chapel Hill, NC: MDC, 1986); Stuart A. Rosenfeld, Edward M. Bergman, and Sarah Rubin, After the Factories: Changing Employment Patterns in the Rural South (Durham, NC: Southern Growth Policies Board, 1985); Southeast Women's Employment Coalition, Women of the Rural South: Economic Status and Prospects (Lexington, KY: Southeast Women's Employment Coalition, 1986).
} 
began to overtake Central Appalachia once again, a clearer picture of the economic problems facing the region took shape. Also, rather than being one of several small pockets of poverty as it was during the 1960s, the Central Appalachian region was part of a larger pandemic of poverty in the American economy during the 1980s. It was clear by the 1980s that the problems with the Central Appalachian economy were part of a larger set of problems within the national economy. ${ }^{15}$

Scholars of Appalachian studies of the 1960s and 1970s have set forth two predominant theories that attempt to explain the causes of Appalachian poverty. The first theory, the culture of poverty model, focuses attention on the people beset by poverty. What characteristics of the people keep them mired in poverty? The second theory seeks to look at the structural reasons for poverty. The internal colonialism model provides insights into the role of the economic development of the Central Appalachian region on the development of poverty. Both theories have serious shortcomings as explanations for the causes of poverty in the region. ${ }^{16}$

\footnotetext{
15 "Comparing Appalachia's Counties with the Nation's," Appalachia 19, $2-4$ (Spring 1986): 8-10; Report of the 1986 Commission on the Future of the South, Halfway Home and a Long Way to Go (Durham, NC: Southern Growth Policies Board, 1986), 5; Gaventa, Smith, and Willingham, 4-5. See also: National Advisory Committee on Rural Poverty, The People Left Behind (Washington: U.S. Government Printing Office, 1967) and Peter Dorner, "Fourteen Million Rural Poor," The Yale Review 68 (1969): 282-292.

${ }^{16}$ Dwight B. Billings and Kathleen M. Blee, The Road to Poverty: The Making of Wealth and Hardship in Appalachia (Cambridge, UK: Cambridge University Press, 2000), 8. See also: Dwight Billings, Mary Beth Pudup, and Altina Waller, "Taking Exception with Exceptionalism: New Approaches to the Social History of Early Appalachia," in Mary Beth Pudup, Dwight Billings, and Altina Waller, eds., Appalachia in the Making: The Mountain South in the Nineteenth Century (Chapel Hill: The University of North Carolina Press, 1995), 1-24; Allen W. Batteau, The Invention of Appalachia (Tucson: The University of Arizona Press, 1990); and Henry D. Shapiro, Appalachia on Our Mind: The Southern Mountains and Mountaineers in the American Consciousness, 1870-1920 (Chapel Hill: The University of North Carolina Press, 1978).
} 
The culture of poverty model, promulgated during the 1960s rediscovery of Appalachia, was closely related to many of the traditional views of Appalachian culture that surfaced with the local color writers of the late nineteenth century. When Appalachian poverty became a national issue during the 1960s, it was not difficult for people who believed the old stereotypes to use a cultural explanation for the terrible poverty that affected Appalachia. For the proponents of the culture of poverty model, Appalachian culture was structurally deficient and produced a region-wide culture of poverty. The work that exemplified the culture of poverty model was Jack Weller's Yesterday's People. Weller noted that there were several inherent traits to Appalachian people, notably individualism, traditionalism, and fatalism, which prevented the mountaineers from becoming an integrated part of the national economy. Worse yet, the mountaineers' fatalism meant that they did not care and took whatever life threw at them without having the desire and motivation to change their lives. ${ }^{17}$ As stated in the work, Weller believed, "The greatest challenge of Appalachia, and the most difficult, [was] its people." 18

Because increased numbers of people in Central Appalachia were characterized as poor during the 1960 s, the culture of poverty model seemed to make sense to many theorists. In some counties, half of the population lived in poverty. For many, this high number of people living in poverty was just too much to be a coincidence; there must

\footnotetext{
${ }^{17}$ Jack E. Weller, Yesterday's People: Life in Contemporary Appalachia (Lexington: University of Kentucky Press, 1966), 7, 13, 32-37; Thomas Ford, "The Passing of Provincialism," in Thomas Ford, ed., The Southern Appalachian Region: A Survey (Lexington: University of Kentucky Press, 1962), 9-34; Billings and Blee, The Road to Poverty, 10. See also: Richard Ball, "A Poverty Case: The Analgesic Subculture of the Southern Appalachians," American Sociological Review 33 (1968): 885-895.

${ }^{18}$ Weller, Yesterday's People, 7.
} 
be some sort of inherent cultural characteristic which explains the high amount of poverty in Appalachia. As sociologist Rupert Vance put it: "Thus mountain isolation, which began as physical isolation enforced by rugged topography, became mental and cultural isolation, holding people in disadvantaged areas, resisting those changes that would bring them into contact with the outside world. The effect of conditions thus becomes a new cause of conditions, but the cause is now an attitude, not a mountain."19 Therefore, for Vance and other proponents of the culture of poverty model, the way to improve the lives of Appalachians and the economic conditions of the region was through changing the culture of the region. ${ }^{20}$

These ideas of a deficient Appalachian culture that kept the region from succeeding influenced policy makers who were attempting to solve the problem of Appalachian poverty. As the Appalachian Regional Commission contended, Appalachia was behind economically because it was "a region apart" and was not fully integrated into the national economy. ${ }^{21}$ As a result, policies focused on integrating the region into the mainstream, rather than on solving the structural problems that led to poverty throughout the country. This model of development, often called the regional development model, met with severe criticism. As one of the critics put it, the model was "concerned with providing social overhead capital, training people for skills for new individual and service jobs, facilitating migration, and promoting the establishment

\footnotetext{
${ }^{19}$ Rupert Vance, “An Introductory Note,” in Weller, Yesterday's People, vii.

${ }^{20}$ Billings and Blee, The Road to Poverty, 10-11; Vance, "An Introductory Note," vii-ix; See also: Rena Gazaway, The Longest Mile: A Vivid Chronicle of Life in an Appalachian Hollow (Baltimore: Penguin, 1969).

${ }^{21}$ Quoted in David Whisnant, Modernizing the Mountaineer (New York: Burt Franklin, 1980).
} 
or relocation of privately-owned industries through a growth center strategy."22 The acceptance of a connection between Appalachian cultural deficiency and poverty encouraged many relief workers to enter the region and attempt to improve the lives of the people by bringing their culture into the twentieth century. As they attempted to implement programs designed to combat the problems in Appalachian culture, namely fatalism, many volunteers began to realize that there were other problems in Appalachia besides cultural ones. It became clear to many working in the region that the people did not suffer from a cultural deficiency. Rather, the people of the region lived in a state of political and economic powerlessness that prevented them from improving their lives and relegated them to generational poverty. Instead of local political and economic structures designed to help the people of the region, there was instead a power base which met the interests of entrenched absentee landholders. Many of the workers took a radical turn, describing Appalachia as an internal colony. ${ }^{23}$

In contrast to the culture of poverty view that Appalachian poverty was a result of Appalachian isolation from the mainstream, both economically and culturally, the internal colonialism model of Appalachian poverty places blame for the condition of the region on Appalachia's connection with, not isolation from, the national economy. As one VISTA (Volunteers in Service to America) worker noted in 1968:

\footnotetext{
${ }^{22}$ David S. Walls, "Central Appalachia: A Peripheral Region within an Advanced Capitalist Society," Journal of Sociology and Social Welfare 4 (1976): 233.

${ }^{23}$ Billings and Blee, The Road to Poverty, 11. See also: John M. Glen, "The War on Poverty in Appalachia: A Preliminary Report," Register of the Kentucky Historical Society 87 (1989): 40-57 and Helen Lewis, Linda Johnson, and Don Askins, eds., Colonialism in Modern America: The Appalachian Case (Boone, NC: Appalachian Consortium Press, 1978).
} 
In West Virginia....as throughout Appalachia, we live in a system of absentee control by large financial and industrial corporations pursuing their economic ends without respect for the lives of the people in the state or region. The responsibility for the damage - political, economic, and social — can be attributed to these colonial exploiters....West Virginia is a rich state. Much wealth has been extracted from West Virginia's natural resources, but little of that wealth has remained in the hands of West Virginians. ${ }^{24}$

At its very core, the internal colonialism model of Appalachian poverty is not only an explanation of why much of the region is poor, but also an attack on the culture of poverty model. Although some proponents of the internal colony theory romanticized "traditional" Appalachian culture in an attempt to depict more clearly the true effect of colonialism on the region, most of the radicals ignored any discussion of Appalachian culture, believing that any discussion of Appalachian culture could degenerate into victim blaming, which is inherent in the culture of poverty model. Instead, theorists supporting the internal colonialism model focused on the stark differences between the two models of Appalachian poverty. ${ }^{25}$

One of the most influential proponents of the internal colonial model, Helen Lewis, summed up the differences between the two arguments by noting that poverty in Appalachia was caused by "either fatalism or the coal industry." ${ }^{26}$ The common acceptance of Appalachia as a deficient culture that kept the region mired in poverty was largely replaced in the 1970s by a view that the coal industry was a symbol of

\footnotetext{
${ }^{24}$ Quoted in Helen Lewis, "Fatalism or the Coal Industry?" in Bruce Ergood and Bruce Kuhre, eds., Appalachia: Social Context Past and Present (Dubuque, IA: Kendall Hunt, 1976), 155.

${ }^{25}$ Billings and Blee, The Road to Poverty, 11-12; See also: Helen Lewis, Sue Kobak, and Linda Johnson, "Family, Religion, and Colonialism in Central Appalachia: Or, Bury My Rifle at Big Stone Gap," in Jim Axelrod, ed., Growing up Country (Clintwood, VA: Council of the Southern Mountains, 1973), 131-156.

${ }^{26}$ Lewis, "Fatalism or the Coal Industry," 153.
} 
Appalachia as an exploited region. The writer who most advocated the internal colonial model was Harry Caudill. In his work on Appalachian Kentucky, Night Comes to the Cumberlands, Caudill argues that the flow of wealth from the natural resources of Appalachia out of the region left Appalachia destitute and helpless. Caudill's work is marred by many of the cultural stereotypes that characterize the culture of poverty model, yet his work is important because it served as an influence for a new generation of scholars who have documented the impact of capitalistic development on Appalachian politics and society. ${ }^{27}$

Both theories do have serious limits in their attempts to describe the nature and origins of Appalachian poverty. Culture of poverty theory, of course, is centered around a faulty view of Appalachian culture that causes one to think that the traits of the culture of the region are static and unchanging. Because the culture of poverty theory contends that Appalachian culture is unchanging and monolithic, it encourages the development of faulty images of the region and its people. Fatalism, for example, leads to an argument that the people of Appalachia would accept anything life threw at them, with little or no complaint. This theory essentially denies agency for the common people, providing a negative, and basically false, view of the region's inhabitants. Despite the serious problems with culture of poverty theory, the theory did bring to light the endemic poverty of the region and the problems poverty created for families who were forced to live in that state. Culture of poverty did err in describing

\footnotetext{
${ }^{27}$ Billings and Blee, The Road to Poverty, 12; See also: John Gaventa, Power and Powerlessness: Quiescence and Rebellion in an Appalachian Valley (Urbana: University of Illinois Press, 1980); Appalachian Land Ownership Task Force, Who Owns Appalachia? Landownership and Its Impact (Lexington: University Press of Kentucky, 1983); and Rodger Cunningham, Apples on the Flood: The Southern Mountain Experience (Knoxville: University of Tennessee Press, 1987).
} 
the causes of poverty in terms of essentialist family characteristics, but it did bring the problem of poverty to the attention of reformers and policy makers. ${ }^{28}$

The internal colonial model of poverty in Appalachia is important because it focuses attention on the extent of absentee, outside ownership of Appalachia's mineral resources and land. There have been many negative effects of this large-scale absentee ownership, which has had a significant impact on local political and economic structures. Many jurisdictions never have taxed absentee owners of mineral resources at a fair rate nor have independent political officials come to power to a significant extent. Furthermore, internal colonialism in Appalachia has been a disservice to the region because it prevents economic diversification. There are some serious problems with the internal colonial model, however. First, the proponents of the internal colonial model made a mistake in suggesting that absentee ownership was the only cause of Appalachian poverty. For example, in many parts of the region indigenous coal operators can be found. These operators are often more known for offering low wage jobs with few benefits and poor safety records than were the operations owned by absentee corporations. Second, there are examples of coalfields, particularly in Illinois, which have a much higher rate of absentee ownership. Nevertheless, the people of the Illinois coalfield region do not suffer from the same degree of poverty as do the people

\footnotetext{
${ }^{28}$ M. Maloney and B. Huelsman, "Humanism, Scientism, and Southern Mountaineers," People's Appalachia 2 (1972): 24-27; Stephen Fisher, "Victim-Blaming in Appalachia: Cultural Theories and the Southern Mountaineer," in Ergood and Kuhre, Appalachia, 139-148; Ann R. Tickamyer and Cynthia M. Duncan, "Poverty and Occupational Structure in Rural America," Annual Review of Sociology 16 (1990): 67-86; Billings and Blee, 12-13. See also: David Cattell-Gordon, "The Appalachian Inheritance: A Culturally Transmitted Traumatic Stress Syndrome," Journal of Progressive Human Services 1 (1990): 41-57; Karen Tice and Dwight Billings, "Appalachian Culture and Resistance," Journal of Progressive Human Services 2 (1991): 1-18; and Alan Banks, Dwight Billings, and Karen Tice, "Appalachian Studies, Resistance, and Postmodernism," in Stephen L. Fisher, ed., Fighting Back in Appalachia: Traditions of Resistance and Change (Philadelphia: Temple University Press, 1993), 283-301.
} 
of Appalachia, because Illinois coalfield communities had fairer tax policies and some economic diversification. This is the true weakness of the internal colonial model. By not looking at the problem of capitalist development as a more complex issue and focusing solely on the issue of absentee ownership, the theory fails to show the uneven regional development that is symptomatic of capitalism. ${ }^{29}$

Yet, the internal colonial model provides an important service by transferring attention from cultural and sociological reasons for poverty to historical causes of economic decline in the region. Caudill attempted to provide a historical context for poverty in the region by discussing the industrial period of Appalachian history, including the entrance of timber and coal interests, along with the railroads. Caudill took the discussion a step further by analyzing the development of coal towns and the boom and bust cycles that are endemic in the coal industry. On a regional level, Ronald Eller's Miners, Millhands, and Mountaineers serves as a definitive description of the colonial development of the Appalachian region. Works such as Caudill's and Eller's fail in several ways, however. By focusing all attention on the insertion of outside capital in the region and ignoring local political and economic development, these works imply that Appalachian history only started when outside investors entered the region. The theory ignores pre-industrial Appalachian history. Although the coal industry has been extremely important in the shaping of Appalachian history, it has not been the only factor in the region's development. Furthermore, many of the poorest

\footnotetext{
${ }^{29}$ Billings and Blee, The Road to Poverty, 13-14. See also: Alan Banks, Stephen Fisher, Jim Foster, and Doug Gamble, eds., "Essays in Political Economy: Towards a Class Analysis of Appalachia," Appalachian Journal 11 (1984): 19; Curtis Seltzer, Fire in the Hole: Miners and Managers in the American Coal Industry (Lexington: University Press of Kentucky, 1985); Janet Smith, David Ostendorf, and Mike Schechtman, Who's Mining the Farm? (Rochester: Illinois South Project, 1978).
} 
counties, particularly in Eastern Kentucky, produce very little coal. Some other reason must explain the prevalence of poverty in these counties. In their important work, The Road to Poverty, Dwight Billings and Kathleen Blee attempt to solve the complex problem of Appalachian poverty in a more sophisticated way than either the culture of poverty or internal colonial model. Billings and Blee examine rural poverty within the context of time and space. Billings and Blee investigate the historical development of Appalachian Kentucky, economically, politically, and culturally. The authors use the best aspects of both internal colonial and culture of poverty models by understanding that Appalachia must be studied in relation to capitalist development and by analyzing cultural reactions to economic struggles, including reciprocity among kin. In contrast to the more simplistic earlier theories, Billings and Blee also focus on the development of political institutions. ${ }^{30}$ In sum, Billings and Blee find that "capitalist markets, state coercion, and cultural strategies worked together to set and keep Appalachian Kentucky on a distinct pathway that might be called Appalachia's road to rural poverty.",31 Another theory explaining the reason for Appalachian poverty has been promulgated by Paul Salstrom in his work Appalachia's Path to Dependency. Salstrom, drawing heavily on dependency theory, argues that Appalachia's preindustrial subsistence lifestyle was not prepared to deal with the industrial transition of the region. Because of the changing economy in the region, the subsistence farmers became dependent on the extra income provided by industry, beginning a cycle of dependency that, in Salstrom's view, extends to the present day. As the

\footnotetext{
${ }^{30}$ Billings and Blee, The Road to Poverty, 14-15.

${ }^{31}$ Ibid., 16.
} 
industrialization of the region worked to supplement the subsistence activities of Appalachian families through the extra income it provided, the level of subsistence grew as the population increased as industry brought in more workers to serve its labor needs. The dependency of the people of Appalachia continued to grow as a result of this phenomenon. Because of this dependency, Salstrom goes on to argue, Appalachia's people were ill-equipped to deal with the decline of industry and soon entered into a new phase of dependency, that of dependency on the federal government. ${ }^{32}$

What exactly is dependency and does it automatically result in poverty?

Theotonio Dos Santos defines dependency as:

By dependency we mean a situation in which the economy of certain countries is conditioned by the development and expansion of another economy to which the former is subjected. The relation of interdependence between two or more economies, and between these and world trade, assumes the form of dependency when some countries (the dominant ones) can expand and be self-sustaining, while other countries (the dependent ones) can do this only as a reflection of that expansion, which can have either a positive or negative effect on their immediate development. ${ }^{33}$

In other words, dependency theory argues that the development of a country's, or a region's, economy can be hindered by both internal and external conditions. Modernization theory, which will be explained below, is more accurate when discussing the effect of internal, local obstacles on economic development. By contrast, external obstacles to economic development require a different explanation.

\footnotetext{
${ }^{32}$ Paul Salstrom, Appalachia's Path to Dependency: Rethinking a Region's Economic History, 17301940 (Lexington: The University Press of Kentucky, 1994), viii.

${ }^{33}$ Quoted in Richard White, The Roots of Dependency: Subsistence, Environment, and Social Change Among the Choctaws, Pawnees, and Navajos (Lincoln: University of Nebraska Press, 1983), xvii.
} 
Dependency theory provides an appropriate explanation for the problems facing those areas beset by external control of resources. Economic dependency prevents economic development from indigenous sources. In Appalachia, this means that the extractive industries are almost totally under the control of outside investors. This has led to dependent development as the outside capitalists formed an alliance with the region's elite to control industry in the region. ${ }^{34}$

Along with the analysis of Billings and Blee, Salstrom's analysis provides important insights into the economic condition of McDowell County during the postwar period. The detrimental effect of deindustrialization in McDowell, as will be shown, is a direct result of many complex factors. First, and perhaps most important, the lack of economic diversification in McDowell County resulted in high levels of unemployment and poverty when the coal industry mechanized during the "bust cycle" of the 1950s. Second, it is clear from the evidence that there was an alliance between the coal industry and the elite class of McDowell County. Although it is somewhat unclear whether there was a true dependent relationship between the industry and the elites, it is clear that the political leadership of the county did not even consider a need for alternate forms of employment. As a result, the political failure of McDowell County exacerbated the negative aspects of deindustrialization. There were some weaknesses in Salstrom's theory, as well, particularly in his discussion on preindustrial Appalachia. Salstrom argues that the subsistence lifestyle of preindustrial Appalachians failed to provide them with the necessary tools to adequately adjust to the industrialization of the region. In a sense, Salstrom's position leads one to assume that

\footnotetext{
${ }^{34}$ Salstrom, Appalachia's Path to Dependency, ix.
} 
the entire region was made up of small farmers who did not have access to, or even knew about, national markets. This is an oversimplification of the economic relationships of early Appalachians. Early mountaineers had a market mentality, even if poor transportation systems did not allow them to take full advantage of this mentality. Four antebellum industries support this assertion, livestock, iron, salt, and timber. When possible, West Virginians provided goods for the country and were fully integrated into the national economy. ${ }^{35}$

An antecedent for culture of poverty theory, modernization theory maintains that there is an evolutionary cycle in economic development. All regions and countries go through the different cycles at different points, depending on if they are located in the core or the periphery of the world capitalist economy. For modernization theorists, development is an evolutionary process. Development can only be achieved by transfer from core to periphery. What should be transferred? This is where the modernization theories diverge from one another. All of the answers vary depending on the specific theory, but most modernization theories argue that modern culture and elites who would implement modern policies should be brought into the peripheral regions. Modernization theories have some very significant deficiencies. Other than the deficiencies involved in the culture of poverty theory, modernization theories in general have been criticized for disregarding many of the economic relationships between countries and regions. Regions do not seem to be underdeveloped because of the lack of free markets or other modernizing economic factors; those factors are usually in

\footnotetext{
${ }^{35}$ See: Ronald L. Lewis, Transforming the Appalachian Countryside: Railroads, Deforestation, and Social Change in West Virginia, 1880-1920 (Chapel Hill, The University of North Carolina Press, 1998).
} 
countries and regions well before the period in question. The problem in economic underdevelopment is not in the absence of "modern" factors, but rather the relationship between the society in question and those modern factors. As one critic argued:

Sociologies of development dominant in the West thus come to posit a transition from a fictional stage to an impossible one. By concentrating on current characteristics of industrial societies, they neglect the fact that these traits, as well as those of underdeveloped societies, are themselves evolving and that social change in each type of society occurs in interaction with the other type. $^{36}$

Besides the culture of poverty theories, other modernization theories include neoclassical development theory, which argues that the exportation of free-market economics to peripheral regions can provide for the development of the region, and modernizing elites theory, which leads to culture of poverty theory by arguing that elites who can foster development must go into a region and change the value system of the periphery. ${ }^{37}$

As with the culture of poverty theory, the internal colonial theory is the intellectual descendent of another broad group of neo-Marxist theories. Unlike the modernization theories, the neo-Marxist theories believe that uneven development is inevitable in a capitalist economy. As Ada Haynes put it, "the driving force in such a system is extraction of surplus value from labor; it is only because of this extraction of surplus value that capital accumulation can occur."38 In other words, the capitalists

\footnotetext{
${ }^{36}$ A. Portes, "On the Sociology of National Development: Theories and Issues" American Journal of Sociology 82 (1976): 74.

${ }^{37}$ Ada F. Haynes, Poverty in Central Appalachia: Underdevelopment and Exploitation (New York: Garland Publishing, 1997), 9-13.

${ }^{38}$ Haynes, Poverty in Central Appalachia, 21.
} 
seek to exploit the underdeveloped region by extracting its raw materials and taking advantage of the people's labor to increase their profit line. Whereas modernization theories see the market system as part of a natural process that doles out all the benefits of production in a fair and just way, neo-Marxist theorists contend that the "free market" is a social construct that allows individuals with political and economic power to rule and exploit others. As a result, the market is an institution that legitimates the extraction of surplus value from the worker to the benefit of capitalists. Haynes makes this argument in her work Poverty in Central Appalachia. Haynes argues that her research shows that not only does the market cause poverty, but also that the poverty thus created serves the interests of capital within the region. By evaluating the surplus value of labor in the region, Haynes finds that there is an above average rate of surplus value in Appalachia, which shows a high rate of exploitation. In sum, Haynes asserts that in order to understand Appalachian poverty, theorists must examine the economic relationships of the region, rather than focusing on culture or the lack of an elite class. ${ }^{39}$ As the 1980s dawned, poverty became more and more of a problem for the entire country, not only Appalachia. The policy focus changed, however, from one of a war on poverty to a war on welfare. Many policymakers and theorists believed that welfare programs tended to create more social problems by making work less desirable and increasing the amount of delinquency and crime. Many of the supporters of this position follow Charles Murray's position. Murray, in his book Losing Ground, argues that not only do welfare policies fail to decrease the incidence of poverty, these policies

\footnotetext{
${ }^{39}$ Ibid., 21, 143.
} 
cause the social problems listed above. Instead, Murray argues that the government should cut welfare programs so that people of working age would have "no recourse whatsoever except the job market, family members, friends, and public or private locally funded services." ${ }^{40}$ To meet this goal, the government should abolish "AFDC (Aid to Families with Dependent Children), Medicaid, Food Stamps, Unemployment Insurance, Worker's Compensation, subsidized housing, disability insurance, and the rest." ${ }^{41}$ In essence, Murray believes that a free market approach to labor is most desirable. He contends that the poor must be threatened with a severe crisis to insure that they will work, that the free market economy can create enough jobs for all who want to work, and that work ends financial deprivation. Murray insists that the inherent problem with American welfare policy is that it tries to fix an assumed problem in the American economy rather than focusing on ensuring compliance by individuals of sound free market principles. ${ }^{42}$

The father of capitalist theory, Adam Smith, actually took a less harsh approach to the question of poverty than Murray. Smith insisted that even in a free market economy, there would be time when poor people would not be able to find work. On top of this assumption, Smith also argued that even when the market works well and work is available some people will be unable to make enough to have a standard of living that is not beset by crisis. Smith contended that certain factors, particularly the

\footnotetext{
${ }^{40}$ Charles Murray, Losing Ground: American Social Policy 1950-1980 (New York: Basic Books, 1984), 227-228.

${ }^{41}$ Ibid.

${ }^{42}$ Richard A. Couto, An American Challenge: A Report on Economic Trends and Social Issues in Appalachia (Dubuque, IA: Kendall Hunt Publishing Company, 1994), 30-31.
} 
supply and demand of labor, would explain the prevalence of poverty. Smith also discussed the exploitation of the poor by the rich through governmental action. It is odd that writings by such proponents of the free market like Murray only discuss the conservative side of Smith and not the side concerned with the plight of the poor. Murray argues that the market is the surest way to peace and stability in society, which was Smith's primary goal for society. ${ }^{43}$

A number of scholars offer serious criticisms of Murray's position. For example, Robert Kuttner argues that positions such as Murray's describe an ideal freemarket economic situation that allows policymakers to ignore systematic problems, such as poverty and social justice issues. Kuttner's analysis, and others like it, allow for an in-depth discussion of the specific causes of poverty which is not hindered by the laissez-faire ideology of scholars such as Murray. This was particularly important during the 1980s as the incidence of poverty increased substantially. The rate of poverty in the United States, as defined by the U.S. Census Bureau, actually declined between 1965 and 1985. By 1989, however, the rate of poverty was larger than the 1969 rate. By 1991, the poverty rate stood at 14.2 percent. As a result, it became clear that poverty was truly a national problem by the 1990 s, not just a regional problem. ${ }^{44}$

The number of Americans suffering from poverty does not tell the entire story, however. Not only do Americans recognize that the War on Poverty failed to eradicate poverty from the country, they also realize the complex reasons for poverty. Of course

\footnotetext{
${ }^{43}$ Ibid., 31.

${ }^{44}$ Ibid., 31-32; Robert Kuttner, The End of Laissez-Faire: National Purpose and the Global Economy After the Cold War (New York: Alfred A. Knopf, 1991), 286-287.
} 
there will always be ideologues like Murray who blame the victim for poverty, but many scholars realize there are structural causes of poverty. Isabel Sawhill, for example, identified five areas of emphasis in the literature on American poverty: demographics, economic performance, human capital investments, income transfers, and the growth of an underclass. One reason for the increase in poverty is the increase in the number of households headed by women. For numerous reasons, households led by women are more likely to live in poverty. As a result, as the number of female headed households increases, so does the number of people living in poverty. This was an issue particularly after 1970 . Economic performance also has an important impact on poverty. The health of the economy affects poverty, because most poor people work in one way or another. Economic growth reduces the number of white male headed households in poverty but does not affect other groups as much. Also, economic recessions widen the gap between rich and poor and as a result tend to drive the poverty rate up. Despite these trends, even in good economic times there has been an increase in the earnings gap between rich and poor. ${ }^{45}$

The third area emphasized by poverty policymakers is in human capital investments, which describe programs designed to improve the job skills of the poor in an attempt to improve the employment opportunities for those mired in poverty. These programs can include improved educational opportunities and job training programs. This has been one of the most popular ways to fight poverty since the 1960s but the

\footnotetext{
${ }^{45}$ Isabell V. Sawhill, "Poverty in the U.S.: Why Is It So Persistent?” Journal of Economic Literature 26 (September 1988): 1086-1092; Kathryn H. Porter, Poverty in Rural America: A National Overview (Washington: Center on Budget and Policy Priorities, 1988), 28; Couto, An American Challenge, 36-37.
} 
increased rates of poverty cloud the effectiveness of such programs. Although education and training prepare individuals for good jobs, there must be available work for those who want jobs. As a result, job training programs can lead to success for individuals but have an overall record of failure. Of course, debates continue to rage about the amount of funding provided for the educational programs. Therefore, education and human infrastructure continue to be some of the best strategies to fight poverty. ${ }^{46}$

The fourth emphasis of the literature deals with income transfer which describes programs that provide assistance to the poor, financial or otherwise. These programs are extremely unpopular with the general public and certain theorists, notably Murray. Many policy makers expect the poor to work their way out of poverty without resorting to accepting a handout. Although spending on social welfare programs rose significantly since the 1960 s, welfare payments are not high enough to provide a financial alternative to working. Furthermore, about 80 percent of the money spent on social welfare programs goes to programs designed as social insurance or designed to prevent people from becoming poor. The fifth area of emphasis is on the growth of the underclass. This phenomenon is difficult to see, however. It does suggest that poverty is concentrated in several regions, including both the inner cities and regions in the rural South, including rural Appalachia. ${ }^{47}$

\footnotetext{
${ }^{46}$ Sawhill, "Poverty in the U.S.," 1092-1097; Couto, An American Challenge, 37.

${ }^{47}$ Sawhill, "Poverty in the U.S.," 1097-1113; Couto, An American Challenge, 39.
} 
My study will examine the socioeconomic impact of deindustrialization on McDowell County. Chapters One and Two will provide some background information to set the stage for the deindustrialization of the county. Chapter One will discuss the industrial period in the county. Of particular note is how the unique development of the coal industry in Central Appalachia led to the creation of a community centered on common experiences. Chapter Two provides the background to the mechanization of the coal industry by examining the impact of the Great Depression and the New Deal on the McDowell County coal industry. Specifically, the National Industrial Recovery Act and, later, the Wagner Act guaranteed labor's right to organize and bargain collectively. Because of the increased labor costs, coal operators began implementing labor-saving machinery in order to cut labor costs and increase their companies' profit margins.

Chapters Three and Four provide the specific causes of deindustrialization from the business and labor communities. Chapter Three discusses the economics of coal that led to the deindustrialization of McDowell County. Because of the competition from alternative fuels such as oil and gas, coal companies decided to mechanize on a large scale in order to stabilize their profit margin. Companies that did not have the resources to mechanize often fell by the wayside. The result of this phenomenon was a decline in the job market for workers in the coal industry. Whereas Chapter Three discusses the role of industry in deindustrialization, Chapter Four examines the role of the United Mine Workers of America (UMWA) in the process. From the beginning of the twentieth century, the union's policy was to support mechanization as a way to improve safety and the standard of living for the workers who remained in the mines. 
John L. Lewis, the union's president for four decades, used this position to win approval for a health and pension plan known simply as "the Fund." The union failed in one important way, however. The UMWA had full control over how the Fund's money would be used and could have used it to soften the effect of unemployment on displaced miners. Lewis, however, failed to ask for a large enough royalty payment to fund the system of union hospitals created by the agreement, much less anything else. The union had a unique opportunity to help its members move out of the coal industry, but failed miserably.

Chapters Five and Six examine the social impact of deindustrialization on the people of McDowell County. Chapter Five discusses out-migration, the most prominent reaction of displaced miners. Because there was a lack of diversification in the economy of the southern West Virginia coalfields, workers who lost their jobs had few options for employment at home. Most made a conscious decision to move to alternate destinations for work instead of facing certain poverty. Chapter Five examines the migrants' move and life in the destination cities. This chapter will examine the wealth of literature on Appalachian migration and attempt to compare the McDowell experience with the rest of Appalachia. Chapter Six examines the lives of people who decided, for one reason or another, to stay in McDowell County. For many of them, the lack of employment opportunities meant a life of poverty. The chapter will place McDowell into a national context, as well as examine the economic fluctuations that faced the people of McDowell County after 1960. With the energy crisis of the 1970s, coal operators reopened many of the mines closed during the previous two decades, increasing the number of people employed in the McDowell County coal 
industry. By the 1980s, the coal industry once again left McDowell County, leaving many people either unemployed or employed in the small, non-union mines that make up the bulk of the current coal mining operations in the county. 


\section{Chapter One \\ The Birth of King Coal: The Development of a Coalfield Community}

During the late nineteenth century conditions developed, particularly

improvements in transportation, which led to the creation of a dynamic coal industry in

Central Appalachia. Outside capitalists waited for the opportunity to enter the region in

order to exploit the natural resources of coal and timber found throughout the mountain region of West Virginia, Virginia, and Kentucky. With industrial development, coal operators needed a reliable source of labor. Native Appalachians provided much of the industry's labor needs, but to complete the workforce they imported immigrants from Europe and African Americans from the South. With the influx of labor, operators realized another problem, that of housing. Since much of the region was rural at the dawn of the industrial age in the late nineteenth century, coal operators had to build communities to house the workers brought in to mine the coal. Operators had another reason for building the coal towns that dotted the region, however. By owning the houses in the towns, operators could use the houses as a means of control to keep the unions out of the Central Appalachian coalfields. The unique experiences of the miners and their families in the coalfields resulted in the development of a new, diverse sense of community. Although there was some racial and ethnic tension in the region, miners more often developed a unique community relationship with their peers based on the common work and community experience found in the southern West Virginia 
coalfields. ${ }^{1}$ For example, Helen Goodman, a native of Wilco in McDowell County,

recalled how the community used to come together:

There's lots of memories. We used to have a larger community than we have now. It's all - a lot of it torn away. It was a town - a little community - of love. Everybody loved one another. If there was illness in the family, the neighbors would go by, help take care of them. Sit at night with the sick so the family could sleep and rest. We would go from one door to another to help people with their work. With anything that had to be done, everybody was helpful. It was a town - a community-of love. ${ }^{2}$

Despite the problems with the coal industry, particularly the threats of death, injury, and occupational illness, some members of the community consistently showed loyalty to the industry because of common experiences and benefits derived from working in the mines. Angeline Harmon grew up in McDowell County during the 1920s and 1930s and spoke of this loyalty in a 1992 interview.

I think it's one of the greatest things that God ever created. I really do. I think it's one of the greatest things God ever made is coal because it's giving me my benefits. I know it killed my husband because he died of silicosis. My daddy had a heart attack stemming from a lung infection, but I wouldn't really swap what I've had all my life. With the love that my mama and daddy had for all of our children... and the love that's been in this family, I wouldn't swap it for nothing in this world. ${ }^{3}$

State government officials knew of the existence of coal in the western part of

Virginia as early as the eighteenth century. The extent of coal deposits were so

\footnotetext{
${ }^{1}$ A good description of the racial tensions found in the southern West Virginia coalfields can be found in Joe William Trotter, Coal, Class, and Color: Blacks in Southern West Virginia, 1915-1932 (Urbana: University of Illinois Press, 1990) and Alice E. Carter, "Segregation and Integration in the Appalachian Coalfields: McDowell County Responds to the Brown Decision," West Virginia History 54 (1995): 78104.

${ }^{2}$ Helen Goodman, interview by H. Renee Viers, 1 July 1992, tape recording and transcript, Eastern Regional Coal Archives, Craft Library, Bluefield, WV.

${ }^{3}$ Angeline Harmon, interview by H. Renee Viers, 2 July 1992, tape recording and transcript, Eastern Regional Coal Archives, Craft Library, Bluefield, WV.
} 
immense that Thomas Jefferson wrote in his Notes on Virginia, "In the western country coal is known to be in so many places, as to have induced an opinion, that the whole tract between the Laurel Mountain, Missisipi, and Ohio yields coal." ${ }^{, 4}$ The exact value of the coal reserves, however, would not be known until the beginning of the industrial age, when the needs of the steel industry provided an impetus to the development of the coal industry. With the knowledge of the coal reserves, the new state of West Virginia began promoting its untapped wealth of natural resources as early as 1864 . In 1870 the state sponsored the publication of the West Virginia Handbook and Immigrants Guide. Written by Joseph H. Debar, the handbook encouraged new immigrants to the United States to come and work in the West Virginia coalfields. It was essential for West Virginia to encourage industry, because there were few economic opportunities available in the rural, more mountainous regions of the state. Many developers and state officials believed that promotion of the natural resources of West Virginia could overcome geographical barriers of communication and transport. But, the early advertising companies promoting the coal industry were largely ineffective in southern West Virginia. At the end of the 1870s, southern West Virginia still was a rural and agrarian region. Farmers, hunters, and extended families—-sometimes called clansoccupied the region. It was not until the entrance of the railroad into southern West Virginia in the late nineteenth century that the region became industrialized. The growth of the coal industry transformed southern West Virginia into an industrialized

\footnotetext{
${ }^{4}$ Thomas Jefferson, Notes on the State of Virginia, ed. William Pedan (Chapel Hill: University of North Carolina Press, 1954), 28.
} 
and economic colony of outside forces that possessed the capital needed to infiltrate the region. $^{5}$

Despite the possibilities afforded by the vast coal deposits of southern West Virginia, the coal industry was not the first industry in the Southern Mountains. The timber industry entered McDowell County before coal could gain a foothold. The wealth of virgin timber attracted many businessmen to invest in lumbering interests. Major lumber companies entered McDowell County and had reached peak production by 1895 . Although the railroad transported most timber in McDowell, railroad officials primarily built the Norfolk and Western Railroad to take advantage of the enormous coal reserves. The promotion of coal by the state government as a more profitable industry hindered the progress of the timber industry and tied the future of the county to coal. Despite this significant advertising effort, the state's promotion of the coal industry was not the most influential factor in hastening the development of coal mining. Private speculators knew that a fortune could be made in coal lands, and so they threw enormous amounts of energy into promoting the coalfields. ${ }^{6}$

\footnotetext{
${ }^{5}$ Phil Conley, History of the West Virginia Coal Industry (Charleston, WV: Education Foundation, 1960), 95; David Alan Corbin, Life, Work, and Rebellion in the Coal Fields: The Southern West Virginia Miners, 1880-1922 (Urbana: University of Illinois Press, 1981), 1-2; Ronald Eller, Miners, Millhands, and Mountaineers: Industrialization of the Appalachian South (Knoxville: University of Tennessee Press, 1982), 46-47; Joseph Lambie, From Mine to Market: The History of Coal Transportation on the Norfolk and Western Railroad (New York: New York University Press, 1954), 27-28; Winthrop D. Lane, "Black Avalanche," Survey 47 (March 25, 1922): 1044; Jerry Bruce Thomas, "Coal Country: The Rise of the Southern Smokeless Coal Industry and its Effect on Area Development, 1872-1910," PhD dissertation, University of North Carolina, 1971, 50-55; John A. Williams, West Virginia and the Captains of Industry (Morgantown: West Virginia University Library, 1976), 166.

${ }^{6}$ Conley, History, 228; Edwin A Cubby, "Timbering Operations in the Tug and Guyandot Valleys in the 1890's," West Virginia History 26 (1965): 116; Ronald L. Lewis, Transforming the Appalachian Countryside: Railroads, Deforestation, and Social Change in West Virginia, 1880-1920 (Chapel Hill: University of North Carolina Press, 1998), 60; Robert Y. Spence, The Land of the Guyandot: A History of Logan County (Detroit: Harlo Press, 1976), 161-202.
} 
Speculators had their eye on McDowell County and began to enter remote areas of the county during the 1880s. In order to gain control of the land and, more importantly, mineral rights, land speculators resorted to unscrupulous methods. To evict the native landholders, speculators often found a local federal judge who, for a bribe, agreed to rule that the "deeds" held by speculators were the original and legal deeds. Despite the support of the United States Supreme Court, many of the county's natives could not afford the legal fees necessary to appeal local decisions. The arrival of the speculators into McDowell County first sparked a major land boom, soon followed by the eviction of native landowners. This began a long tradition of economic and political corruption in the coalfields of southern West Virginia. ${ }^{7}$

Large seams and hillside exposure made entry easy, and greatly impacted the industry's development in, McDowell County. The shape of the seam above the water level eliminated the problem of drainage. Elevation of the mines made pumping water unnecessary because the hills provided excellent drainage, and facilitated hauling the coal out of the mines. Without these advantages, the coal industry in West Virginia may not have developed as extensively as it did. Despite the major geographical advantages of West Virginia, there was one primary obstacle that had to be met before widespread industrial growth of southern West Virginia could begin, that of transporting coal to market. The lack of adequate transportation out of the region rendered the southern West Virginia coal useless. In the early 1880s, officials of the

\footnotetext{
${ }^{7}$ Corbin, Life, Work, and Rebellion, 3; Eller, Miners, Millhands, and Mountaineers, 48, 52; Spence, Land of the Guyandot, 185-194; Thomas, "Coal Country," 12-13; John Alexander Williams, West Virginia: A Bicentennial History (New York: W.W. Norton and Company, 1976), 107-8.
} 
Norfolk and Western Railroad began construction of a rail line into the coalfields of the Flat Top region, an area that included the Pocahontas and Winding Gulf coalfields, and encompassed McDowell, Mercer, Wyoming, and Raleigh counties. ${ }^{8}$

In the early 1880 s, however, railroad companies neither possessed the technological knowledge nor the finances to penetrate the mountains. No capitalist was willing to commit large sums of money to a railroad project in West Virginia without reasonable hope for profit. During this decade railroad companies learned more effective tunneling techniques that allowed the railroads to cross the mountains, prompting notable financiers, among them John D. Rockefeller, to pay for the building of railroads. The first wave of railroad construction opened up the Flat Top coalfield of Mercer and Raleigh counties. Soon after the construction of the first railroads, speculators bought the majority of land in southern West Virginia, and thereafter speculation became a distinguishing characteristic of the early industrialization of the region. The coal industry, however, did not enter McDowell County until 1892 and 1893, with the completion of the Norfolk and Western Railroad's Ohio Branch, which traveled through Mingo County to Kenova on the Ohio River. The construction of the line gave McDowell County mines an opening in the coal markets of the Great Lakes region because it connected the county with the industrial centers of the Midwest. The

\footnotetext{
${ }^{8}$ L.C. Anderson, letter to the editor, Outlook 82 (April 28, 1906): 861; W.P. Tams, The Smokeless Coal Fields of West Virginia: A Brief History (Morgantown: West Virginia University Library, 1963), 19; Corbin, Life, Work, and Rebellion, 5; Lambie, From Mine to Market, 40-42; Trotter, Coal, Class, and Color, $12-13$.
} 
new markets gave operators more flexibility by allowing them to sell coal to different markets. $^{9}$

The United States' entry into World War I in April 1917 brought a new vitality to the coalfields. War industries, primarily in the Midwest, needed to produce large amounts of munitions and other wartime necessities. The new munitions factories required coal and because there was a shortage of coal, the industry expanded. Many new mines opened and older mines grew significantly. Throughout the United States, the number employed in coal mining rose from less than 200,000 in 1890 to more than 600,000 in 1920. After the war, there were two other reasons for the continued solvency of the coal industry in southern West Virginia. First, a coal shortage in wartorn Europe allowed McDowell County coal to keep its domination of coal production in the world market. Second, a nationwide strike of union mines in the early 1920 s took these mines out of competition with the non-union mines in McDowell. ${ }^{10}$

The industrialization of southern West Virginia affected traditional ways of life by destroying the extended family clan and close mountain communities that developed in Central Appalachia. ${ }^{11}$ According to Elmer Short, a descendant of one of the first families in McDowell County, "That area (Bradshaw) is what you might call an indogamous $[\mathrm{sic}]$ society. They marry within the community. The only new blood that

${ }^{9}$ Corbin, Life, Work, and Rebellion, 2; Eller, Miners, Millhands, and Mountaineers, 132; Tams, Smokeless Coal Fields, 19, 22-25.

\footnotetext{
${ }^{10}$ Morton Baratz, The Union and the Coal Industry, Reprint edition (New York: Kennikat Press, 1973), 52-57; O.E. Kissling, "Coal Mining in the South," Annals of the American Academy of Political and Social Science 153 (January 1931): 88-89; Malcolm Ross, Machine Age in the Hills (New York: Macmillan Company, 1933), 50-51.

${ }^{11}$ In this work, the word "clan" is used loosely to describe mountain families before industrialization. For further information, consult: Altina L. Waller, Feud: Hatfields, McCoys, and Social Change in Appalachia, 1860-1890 (Chapel Hill: University of North Carolina Press, 1988).
} 
came in was more or less after the mines were developed and after the first World War."12 Clans developed because of the isolation of the mountain regions during the nineteenth century. The support system provided by the clan allowed families to thrive in the wilderness. The Hatfield family, involved in the famous Hatfield-McCoy feud, was the quintessential mountain clan. Although the Hatfield family was involved in industrial activities (which was a major cause of the feud), the family clan ultimately could not survive in an industrializing economy. By the 1890 s, a general perception formed in the media about mountaineer culture as lawless and unsuited to the march of civilization. The media popularized the idea of mountain culture as anarchical by publishing sensationalized accounts of mountain feuds. The Wheeling Intelligencer argued that "Capitalists refuse to come and prospect because they say they are afraid of our outlaws. You cannot get them to go into the interior to inspect our timber and coal lands for fear they will be ambushed."13 The eventual industrialization of the region destroyed the clan and forced families to make tough decisions. Members of the families who had lived in the area prior to industrialization increasingly chose different paths; some became coal operators, while others entered the mines as common miners. ${ }^{14}$

The native, white population of southern West Virginia could not supply a work force adequate for the needs of the growing coal industry. In 1880, McDowell County had a population of only 3,078 , of whom 3,071 were white, so the coal companies were

\footnotetext{
${ }^{12}$ Ira Short, Interviewed by H. Renee Viers, 2 July 1992, tape recording and transcript, Eastern Regional Coal Archives, Craft Library, Bluefield, WV.

${ }^{13}$ Wheeling Intelligencer, 23 November 1889.

${ }^{14}$ Corbin, Life, Work, and Rebellion, 7; Waller, Feud, 232.
} 
required to import labor from other areas. By 1890, McDowell County's population had risen to 7,347 , of which 5,260 , or 71.7 percent, were white. Two decades later, in 1910, the McDowell County population had risen to 47,856, of which 25,196, or 52.6 percent, were American-born whites. ${ }^{15}$ The preponderant majority of whites living in McDowell County were migrants themselves, as the native whites living in McDowell in 1880 could not have reproduced the numbers necessary to mine the coal. Coal operators brought in African Americans from the South and immigrants from Eastern and Southern Europe. Operators recruited both African Americans and Europeans because they worked for significantly lower wages than did native whites. The operators influenced labor recruits by offering them a way of life better than that they had known previously. The recruitment of African American miners increased the rate of black migration and blacks soon formed their own immigration networks. It was difficult for married men to migrate because they invariably left their families behind until they could afford to join the men. Paying African American and European migrants sub-standard wages not only kept operating costs down and profits high, but also served as a basis for the exploitation of McDowell County miners, in which miners did not benefit from the great wealth found in the coalfields. ${ }^{16}$

The bituminous coal mined in southern West Virginia beginning in the early twentieth century quickly became renowned for its superior quality. West Virginia coal had the highest BTU per unit, which is the amount of heat energy produced as coal is burned, and produced the best steam in the United States. It had a low content of ash

\footnotetext{
${ }^{15}$ The African American population in McDowell County increased from 1,569 in 1890 to 5,969 in 1910.

${ }^{16}$ Corbin, Life, Work, and Rebellion, 7-8, 62-63; Trotter, Coal, Class, and Color, 19-25.
} 
and sulphur, which made it the most fuel efficient and best coking coal in the country. The coal from southern West Virginia, particularly that from the New River, Winding Gulf, and Pocahontas (which contains McDowell County) Fields, produced low volatile coal, which means that coal from those areas have a low amount of gas, leading to a lower amount of smoke produced when this coal was burned. Because of the low amount of smoke produced by the coal from these three fields, they are commonly called the "smokeless" coal fields. Coal from the smokeless fields became extremely popular in many of the cities because of the concerns with pollution. In fact, West Virginia coal became so popular with both industry and the general public that the region's mines captured the most profitable national markets. For instance, the Midwestern industries and the United States Navy both preferred West Virginia coal. McDowell County was probably most affected by the increase in demand. Coal output in McDowell rose from 246,000 tons in 1889 to 3.5 million tons in $1910 .{ }^{17}$

The economic success of McDowell County, and the resultant increase in the number of miners in the county, determined the scope of the effort to organize the miners into a labor union. Organized in 1890 as a result of the merger of National Trades Assembly 135 of the Knights of Labor and the National Progressive Union, the United Mine Workers of America (UMWA) initially was a weak union. In 1898,

\footnotetext{
${ }^{17}$ Rita K. Hessley, John W. Reasoner, and John T. Riley, Coal Science: An Introduction to Chemistry, Technology, and Utilization (New York: John Wiley and Sons, 1986), 81; Charles Carter, "The West Virginia Coal Insurrection," North American Review 198 (Oct. 1913): 457; Justin Collins, "My Experiences in the Smokeless Coal Fields of West Virginia," in Maude A. Rucker, ed., West Virginia: Her Land, Her People, Her Traditions, Her Resources (New York: Walter Neale, 1930), 110-120; S.C. Higgins, "The New River Coal Fields." West Virginia Review (October 1927): 26; Floyd Parsons, "Coal Mining in Southern West Virginia," Engineering and Mining Journal (9 November 1907): 881-884; Adam Shurick, The Coal Industry (Boston: Little, Brown, and Company, 1924), 17-18; Tams, Smokeless Coal Fields, 15; Corbin, Life, Work, and Rebellion, 4-5.
} 
however, the union succeeded in achieving an agreement with the operators in the Central Competitive Field in which the Midwestern operators gave the union recognition in exchange for a promise by the union to organize the coal miners in West Virginia. Membership steadily increased from a low of 33,000 members in 1897 to more than 400,000 in 1917. Many miners came into the union because of their desire for increased benefits and improvements in their quality of life. The activists employed by the UMWA realized that industrial democracy meant the right of the majority to make decisions. The union leaders also realized, however, that an oppressive system, controlled by a strong minority, could trample on the rights of a weaker majority. ${ }^{18}$

The UMWA sought to unionize all coal miners in the United States. Yet, before the election of Franklin Roosevelt in 1932, the union did not make much progress in its efforts to organize southern West Virginia because one of the primary issues that concerned the union was that of uniform national wage rates. The southern West Virginia operators believed that the union was illegal; moreover, after learning of the Bolshevik Revolution in Russia, they saw it as a communist plot to destroy American industry. Most importantly, however, because the union could not secure agreements for uniform wage rates from southern West Virginia companies, these producers could pay lower wages, usually in the neighborhood of 15 to 20 percent lower, which allowed them to compete in the important Great Lakes markets with closer companies from

\footnotetext{
${ }^{18}$ Melvyn Dubofsky and Warren Van Tyne, John L. Lewis: A Biography (New York: Quadrangle, 1977), 13-14; Gary M. Fink, ed., Labor Unions (Westport, CT: Greenwood Press, 1977), 228; John Hutchinson, "John L. Lewis: To the Presidency of the UMWA," Labor History 19 (Spring 1978): 187; Baratz, The Union and the Coal Industry, 52-57; Corbin, Life, Work, and Rebellion, 110.
} 
Ohio and Pennsylvania. ${ }^{19}$ The failure of unionization was one significant contributing factor to the industrialization of McDowell County. ${ }^{20}$

There were many small mines that lined the hollows of McDowell County. They dominated the landscape, yet many mines did not have the technology nor the capacity to mine a significant tonnage of coal. Throughout the history of McDowell County, a few companies produced most of the county's coal. The larger companies had the resources to hire significant numbers of workers, to keep them satisfied with social improvements, and to use machinery to increase the rate of production. One of the most important companies in McDowell County was the United States Coal and Coke Company (U.S. Coal and Coke), which operated mines around the town of Gary, West Virginia. A subsidiary of the United States Steel Corporation, U.S. Coal and Coke had the resources to open many mines in the Gary area. By 1923, the company had become the largest coal producer in West Virginia. The company would be central to the economy of McDowell County for many more years. U.S. Coal and Coke also is important because it pioneered the mechanization of McDowell County mines. The company used the first successful cutting and loading machines in the county in the early 1900s. The cutting machines undercut the coal before a charge of powder was

\footnotetext{
${ }^{19}$ It was also difficult for the union to organize the McDowell County coal fields because of the nature of industrialization. Around the turn of the century, capitalists could begin a mining operation with relatively little capital. This characteristic led to the railroad leasing to numerous small, independent operators, which made it difficult for the union to focus on a few big companies. See: Tams, Smokeless Coal Fields, 24-33.

${ }^{20}$ Baratz, The Union and the Coal Industry, 46.
} 
detonated to loosen the coal. The undercutting machines were electrically driven, short-wall mining machines. $^{21}$

The early machine movement did not decrease the number of mining jobs available in McDowell County, but neither did they cause mass terminations of workers because they were designed to aid the workers, not to replace them. ${ }^{22}$ Each miner's responsibilities included all steps in the mining operation. The miner undercut the coal seam, blasted the coal down, loaded it into cars, and made any necessary safety precautions. It was not until the widespread use of loading machines and the continuous mining machines of the 1950s, which reorganized the work process, that many jobs were lost to machines. ${ }^{23}$

Beginning about the turn of the century, McDowell County experienced rapid economic growth never before seen in the region. Economic historian Mancur Olson argued that rapid economic growth leads to political and social instability. This was true in West Virginia. The political instability that characterized southern West Virginia led to a coalition of pro-coal politicians and businessmen gaining control of local and state governments. The political factions that controlled West Virginia politics during the late nineteenth and early twentieth centuries were deeply connected to the coal establishment. Throughout the early years of the industry, the political

\footnotetext{
${ }^{21}$ Carter Goodrich, "Machine and the Miner," Harper's 154 (April 1927): 649; Edward O'Toole, "Pocahontas Coal Field and the Operating Methods of the United States Coal and Coke Company," Coal Age 23 (March 8, 1923): 401-403; Conley, History, 36; Eller, Miners, Millhands, and Mountaineers, 134.

${ }^{22}$ Besides the undercutting machines, other machines that entered the mines during the first couple of decades of the twentieth century included the moving belt, the electric drill, and loading machines.

${ }^{23}$ Keith Dix, What's a Coal Miner to do? The Mechanization of Coal Mining (Pittsburgh: University of Pittsburgh Press, 1988), 81-82. Although loading machines were used throughout the industry well before the 1950s, many McDowell mines did not use this technology prior to World War II and later.
} 
establishment protected the interests of coal operators by controlling the congressional delegation and the governor; between the 1890s and World War I, every governor of West Virginia was a coal operator, investor, or attorney. Moreover, the politicalbusiness coalition infiltrated the important committees of Mines and Mining, and Labor and Immigration in the West Virginia state legislature. The leaders of the establishment included dynamic gilded age political figures as Governor William A. MacCorkle, and Senators Henry G. Davis and Stephen B. Elkins. The coal operators also dominated local politics in McDowell County. The establishment controlled the county court and the county's Republican Party, leading to a political system that was, as one union official put it, "the willing instrument of the operators." ${ }^{24}$ Until the dawn of the New Deal, McDowell County coal miners could expect little political help for any grievances they may have had against the coal companies. ${ }^{25}$

Despite being controlled by the coal establishment, the West Virginia legislature passed several laws to "aid" miners. Among them were several dealing with the use of scrip. Scrip was a form of payment that could only be used in the company store. The goal of the scrip system was to sell the miner necessary goods at inflated prices. Thus, the system took a miner's wages and gave them back to the company. Although it seemed that the legislature took action to ease the miners' plight, the laws dealing with scrip were designed to comply with federal concerns with the implications of the

\footnotetext{
${ }^{24}$ Corbin, Life, Work, and Rebellion, 12.
}

\footnotetext{
${ }^{25}$ John W. Brown, Constitutional Government Overthrown in West Virginia (Wheeling, WV: Majority Company, 1913), 8-9; Mancur Olson, "Rapid Growth as a Destabilizing Force," Journal of Economic History 23 (December 1963): 529-552; Corbin, Life, Work, and Rebellion, 13-14; Williams, West Virginia, 121-122.
} 
system to legal tender. One law, passed in 1887 , required that coal companies pay their workers in lawful money. A second law, passed in 1891, took a further step and outlawed scrip outright. But the laws passed by the legislature were ineffective. The coal operators had enough political power to ignore the laws prohibiting the use of scrip until the New Deal. Other laws ignored included requirements to keep a checkweighman on the tipples. Until the 1930s, miners were paid by the ton rather than the hours they worked, and without a checkweighman on the tipple, the company could—and often did—shortchange the miner. ${ }^{26}$

Operators also ignored a prohibition, enacted by the legislature, against interfering with peaceful efforts of a union to organize workers. Prior to the New Deal, operators saw the UMWA as a plot that was un-American and harmful to business because the union challenged the operators' control of their property. The companies were also concerned with the threat the union comprised to the prevailing business model of the time; lower pay was required in order for the Appalachian mines to compete. The connection between the coal establishment and political leaders worked to control the miners and, thus, destroy the unionist movement. Because of the lack of political power held by the miners, the state legislature passed laws that seemed to aid the miners, yet were victories for the operators. For example, the state legislature passed a Workers' Compensation law in 1913. The legislation seemed to be a significant victory for the miners, but the law exempted operators from damage suits by injured miners. The statute protected the operators because previous damage suits were

\footnotetext{
${ }^{26}$ Lamar Epperly to Justin Collins, 21 July 1925, Collins Papers; Winthrop D. Lane, Civil War in West Virginia (New York: Arno Press, 1969), 27.
} 
often won by the miners. The political power of the operators was such that the bills that passed the legislature had the blessing of the coal establishment. ${ }^{27}$

The coal operators, determined to keep the union from organizing the southern West Virginia coalfields, unified to oppose the UMWA. Coal superintendent George Wolfe explained the new policy in a letter to the owner of Winding Gulf, Justin Collins: "The operators of the Pocahontas coalfield unanimously agreed by $100 \%$ of the tonnage that this District would make a determined fight against the impending invasion by the United Mine Workers of America. ${ }^{28}$ In addition to flaunting their political power, the coal operators used other methods to keep the union from organizing the southern West Virginia coalfields. Many of the operators in the Pocahontas coalfield—which includes McDowell County — forced their new employees to sign a contract known as a yellowdog contract. The yellow-dog contract was so exploitative that the state court system characterized it as a contract between master and servant. There were several types of yellow-dog contracts, but the most commonly-used one specified that the employer would not employ a member of a union, and that the employee would neither join a union nor aid in the organization of a union. The operators thus tried to get as many employees as possible to sign yellow-dog contracts; then, if the union persisted in organizing McDowell County, the operators intended to secure injunctions against the UMWA for "interfering" with their labor. ${ }^{29}$

\footnotetext{
${ }^{27}$ E.P. Monts to A.B. Fleming, 1 March 1904, A.B. Fleming Papers, West Virginia Regional History Collection, West Virginia University, Morgantown; Samuel Gompers, "Russianized West Virginia," American Federationist 20 (October 1913): 869.

${ }^{28}$ George Wolfe to Justin Collins, 25 June 1920, Collins Papers.

${ }^{29}$ Ibid.
} 
The operators could require their workers to sign yellow-dog contracts because the nature of the coal camps allowed the operators to exercise their power over the miners. ${ }^{30}$ The camps were unincorporated, so the operators had control of everyday life. Within the towns company officials filled such diverse roles as mayor and school superintendent. The mine operator scrutinized every move made by the miners. Operators suppressed political activity among the miners and censored miners' mail to further control their towns. The miner lived in company housing and if a miner lost his job, his family would be put out into the streets. Thus, a miner's job was much more important than a paycheck; his family's survival was at stake. If the company suspected a miner of harboring union sympathizers or of aiding the establishment of a union, the company could, and did, search miners' homes at will. If any unauthorized activity was found to be occurring, the companies could evict the miners without due process of law. The company sent the mine guards to remove the miners and their families from the premises. Guards willfully damaged miners' personal possessions when they roughly dumped miners' belongings into the street. Guards evicted the miners without concern for life or property. ${ }^{31}$

Despite the control exerted by the operators over miners' lives, miners still protested oppressive working and living conditions. Geographic mobility was the most effective protest. Miners drifted from town to town in search of higher wages, improved living and working conditions, and enhanced opportunities for advancement

\footnotetext{
${ }^{30}$ Both coal camps and coal towns are adequate terms to describe the settlements constructed by the coal companies, particularly in the early industrial period. The settlements were largely self-sufficient and both terms are used interchangeably in this work.

${ }^{31}$ Coal Age 4 (July 12, 1913): 66; Betty Cantrell, Grace Phillips, and Helen Reed, "Widen, the Town J.G. Bradley Built," Goldenseal 3 (January 1977): 4; Corbin, Life, Work, and Rebellion, 9-10.
} 
in the workplace. The mobility of southern West Virginia miners eventually led to the development of a strong, collective mentality, because miners worked and lived in many places. Each miner was a member of a large coal mining community that encompassed the five coal fields of southern West Virginia. More importantly, common experiences with operators and camp life brought miners together. The coal operators sought to slow the rate of migration among their miners by hiring married men who had families and were more willing to work harder and longer to support their families than single men. The cost of moving from town to town was so great, and so stressful on the families, that married men were significantly less mobile than single men who had no ties to a specific area. Operators also stemmed the tide of migration by improving conditions in the coal towns. ${ }^{32}$

Mobility became an important form of protest primarily because without the protection afforded by the UMWA, miners had few other options to protest the exploitation of the coal town system. While it is true that political control of the state government by the coal operators adversely affected unionization, the primary reason that miners did not begin to unionize before 1912 was that the union raised concerns, such as higher wages and shorter hours, that were not yet significant to the miners of southern West Virginia. The important issues to the miners were those that they believed affected their families, jobs, and way of life, among them, the mine guard system, free trade, the checkweighman, unfair practices, and the scrip system. The

\footnotetext{
${ }^{32}$ Garnet Fuller, interviewed by H. Renee Viers, 26 June 1992, tape recording and transcript, Eastern Regional Coal Archives, Craft Library, Bluefield, WV; Isaac Hourwich, Immigration and Labor: The Economic Aspects of European Immigration to the United States, Reprint ed. (New York: AMS Press, 1972), 421; Crandall A. Shifflett, Coal Towns: Life, Work, and Culture in Company Towns of Southern Appalachia, 1880-1960 (Knoxville: University of Tennessee Press, 1991), 49; Corbin, Life, Work, and Rebellion, 40-42; Eller, Miners, Millhands, and Mountaineers, 71.
} 
union's priorities did not gain support in southern West Virginia because of the traditional working of the mine system. Higher wages and shorter hours were not important, because the miners did not work set hours and were paid by the amount of coal mined. For example, when discussing the original push for unionism that developed during the 1930s in McDowell County, one miner noted: "Thing[s] got to be such a bad situation you just had to do something. We decided we'd join the union. We wanted to join the union because I call when a man load a car of coal, he get 50 cent or 75 cent for five or six tons of coal. If found two pieces of slate in his car, they take that away from him, call it docking. They dock him.. ${ }^{, 33}$ The labor movement was, at its very core, a fight for human dignity. As another miner, Paul Haynes, noted: "I'm going to tell you what used to happen. It used to be before the union came in, the company had a man and the mule. They put them in the mine. They didn't want the mule hurt, but they didn't care if the man got killed. They could always hire another man, but they had to buy the mule. ${ }^{34}$ Without addressing the concerns that directly affected the miners, the union had little chance of success in southern West Virginia. ${ }^{35}$

The emergence of coal towns on the landscape of McDowell County defined the importance of the coal industry to the miners' way of life. Companies built coal towns, because when the coal operators began to enter McDowell County, the area was desolate. The rural nature of the area required the construction of company housing. Because few settlements could support the influx of laborers pouring into McDowell

\footnotetext{
${ }^{33}$ Fuller Interview.

${ }^{34}$ Paul Haynes, interviewed by H. Renee Viers, 18 June 1992, tape recording and transcript, Eastern Regional Coal Archives, Craft Library, Bluefield, WV.

${ }^{35}$ Corbin, Life, Work, and Rebellion, 26-33.
} 
County, company towns sprang up and began to dominate the landscape around the turn of the century. More miners lived in company housing in West Virginia than in any other state in the union, about 94 percent. The percentage of miners living in company towns in southern West Virginia was even higher, approaching 98 percent. The remoteness of the mountain mines and the domination of the landscape by the company towns made them an integral part of life. The town quickly became the dominant influence on community and social life. The social institutions included in the towns - stores, churches, and recreational facilities — became a form of social power. The companies owned the towns and controlled them in such a way that upheld the interests of the company. The emergence of the coal town constituted another example of the transference of political and social power from traditional sources to the new industrial power, the coal companies. The price of economic success for southern West Virginia was, therefore, political and social control by the companies. ${ }^{36}$

Company towns were also important to the operators because prior to 1900 mountaineers only worked seasonally, when they could leave their farms. These early miners did not think of coal mining as a career. They considered mining as a way to make extra money to supplement their seasonal farm incomes. To combat the labor shortage, and to persuade the mountaineers that mining was the best way to make a living, the operators tried to insert stability by establishing social institutions, such as schools, churches, and civic clubs. The ultimate goal of the coal operators was to secure a more permanent, family-based labor force. Once the labor force was in place,

\footnotetext{
${ }^{36}$ Walter Thurmond, The Logan Coal Field of West Virginia (Morgantown: West Virginia University Library, 1964, 64; Corbin, Life, Work, and Rebellion, 8; Eller, Miners, Millhands, and Mountaineers, 162; Shifflett, Coal Towns, xv.
} 
the companies had to ensure that their workers would not have a reason to leave. The continued migration of unhappy workers and the desire to cultivate the loyalty of workers in order to keep the union out forced the operators to improve continually social conditions in their towns. By the mid-1920s, conditions had improved considerably in the coal towns. Operators installed baths and electric hookups in miners' homes. Such recreational facilities as theaters, restaurants, dance halls, bowling alleys, pool rooms, and baseball fields, constructed by the operators, improved the quality of life in the coal towns of McDowell County. Operators also built clubhouses to house bachelors and newlyweds. The facilities built by the companies helped to soften the sting of the miners' lot in life, yet only larger companies, such as U.S. Coal and Coke, offered such amenities. The smaller operators did not have the capital to offer such benefits to their workers, so it was very difficult for them to keep workers for an extended period of time. Miners simply moved to the larger towns, where houses had indoor plumbing and electric lights. ${ }^{37}$

Operators knew that leisure activities were paramount to the satisfaction of the miners. Thus, most of the coal camps, even the smaller ones, fielded a baseball team that traveled from camp to camp to play games. Operators built the ballfields, bought the uniforms, and subsidized road games to keep the miners satisfied and to keep the union out of McDowell County. Baseball was popular, and crowds of several hundred people attended the games. By the mid-1950s, the county seat of Welch continued the coalfield baseball tradition by fielding a professional baseball team, the Miners, who

\footnotetext{
${ }^{37}$ P.J. Riley to Collins, 3 June 1907, Collins Papers; George Wolfe to Collins, 30 July 1916, Collins Papers; Coal Age 6 (4 February 1914): 295; Coal Age 6 (22 August 1914): 311-312; Eller, Miners, Millhands, and Mountaineers, 186; O'Toole, "Pocahontas Coal Field," 407.
} 
played in the Class D Appalachian League. In a historical sense, the importance of baseball to the residents of the coal towns was another example of how coal affected the everyday lives of the people of the county and created camaraderie among residents. $^{38}$

Another example of the impact of coal on the society of McDowell County was the influence of the in-migrants. In addition to the native white mountaineers, the migrants who entered McDowell were black southerners and Europeans, primarily from eastern and southern regions of the continent. All of the migrants came to West Virginia for the same reason, opportunity. European immigrants probably had the most difficult time adjusting to life in the coalfields. Most could not speak English and simple tasks like communication were difficult. Despite the differences between ethnic groups such as culture and language, European immigrants really assimilated into their communities, especially the children of the original migrants. For example, as one woman living in McDowell County put it, the various ethnic groups "didn't seem to like each other. One day, one of the girls came down to my house. I lived in 44 then, and she said, 'I just cannot understand Miss Jack at all. ....and I don't understand a word she says.' I don't understand them all either. ...but after you stay with them a long time you can understand what they say. They thought I was an angel. They loved me. They ever wanted to love me, they just loved me to death. When my babies would be born, they would come. They had to give you something. That's what they thought

\footnotetext{
${ }^{38}$ Tams, The Smokeless Coal Fields, 56. A recent study describing the rise of baseball in West Virginia, including the support of baseball by coal operators, is William E. Akin, West Virginia Baseball: A History, 1865-2000 (Jefferson, NC: McFarland and Company, 2006).
} 
they had to do. No matter what it is, they had to give you something." ${ }^{, 39}$ This view of different ethnic groups coming together on a small scale was corroborated by another resident of the county, who declared that the ethnic groups "got along well because they were all working for a living. They didn't fraternize too much except maybe on the streets, but they went to different churches and they had different social groups. It was difficult for them to mingle completely together because of their ethnic backgrounds." ${ }^{, 40}$

After the Pocahontas mines opened in 1892, African Americans from Virginia, North Carolina, and Alabama were recruited to work in the coalfields. Professional labor agents were sent to Alabama to persuade African Americans to come to West Virginia. Sometimes these agents doubled as guards hired by the Baldwin-Felts agency, the preeminent mine guard company in West Virginia, but more often companies sent African American agents into Alabama because it was illegal to entice labor to leave Alabama. While Baldwin-Felts men coerced a small number of African Americans into moving to West Virginia, most African Americans came willingly. Despite their common origin in the tenant farming system of the South, blacks migrated to southern West Virginia for several different reasons. First, African Americans could make a better living as coal miners than as tenant farmers. The second, and probably the most important, reason was that West Virginia had few official Jim Crow laws and the ones on the books dealt with miscegenation and education. True, many public facilities were separate, but unlike other southern states, facilities for African

\footnotetext{
${ }^{39}$ Lola Dunigan, interviewed by H. Renee Viers, 17 June 1992, tape recording and transcript, Eastern Regional Coal Archives, Craft Library, Bluefield, WV.

${ }^{40}$ Leo Signaigo, interviewed by H. Renee Viers, 30 June 1992, tape recording and transcript, Eastern Regional Coal Archives, Craft Library, Bluefield, WV.
} 
Americans and whites were somewhat similar in quality. African Americans worked in both skilled and unskilled positions. Because of the inherent race prejudice in the larger society, blacks rarely assumed positions of authority in the mines (e.g. mine foreman). Race relations were intimate and friendly due to the close proximity in which the miners worked. White and black miners worked and ate together. Systematic white discrimination of black miners did not occur because there was no separate pay scale for white and black miners. ${ }^{41}$

Because of the equitable pay scale, there was a decrease in race consciousness in favor of an increase in class consciousness. Many of the miners formed a cohesion because they perceived themselves to be members of an oppressed class. For example, Elmer Rose, a white miner, stated when asked about the relationship between white and black miners: "They got along pretty good. Best friends that I've ever had, I'll say, have been black people. ${ }^{, 42}$ Both white and black miners had to support one another because the coal companies politically and socially oppressed all miners, regardless of race. One interesting example of good relations between African American and white miners was found in the "Cinder Bottom" section of Keystone, a merchant town in the eastern part of the county. Cinder Bottom was famous as a coalfield "red light" district. Some of the brothels in Cinder Bottom catered to black patrons only, some to white patrons only, but most were not particular about the race of their customers. In contrast, a resident of Tazewell County, the Virginia county just south of McDowell,

\footnotetext{
${ }^{41}$ James T. Laing, "The Negro Miner in West Virginia," in Blacks in Appalachia, ed. William H. Turner and Edward J. Cabbell (Lexington: University Press of Kentucky, 1985), 72-77; Eller, Miners, Millhands, and Mountaineers, 165; Trotter, Coal, Class, and Color, 21.

${ }^{42}$ Elmer Rose, interviewed by H. Renee Viers, 10 June 1996, tape recording and transcript, Eastern Regional Coal Archives, Craft Library, Bluefield, WV.
} 
was appalled with what he saw in Keystone when he visited the town in the early twentieth century. The primary problem this visitor saw with Keystone was not necessarily the debauchery and immoral behavior, but the fact that white prostitutes often entertained the black miners of the region. ${ }^{43}$

Black residents also held considerable political influence in parts of McDowell County. The white officials of Keystone had to cater to the wishes of the black community, else they would find themselves voted out of office very quickly. From the mid-1920s to 1995, McDowell County sent at least one black member to the West Virginia House of Delegates. The African-American community even published its own newspaper, the McDowell Times. There were many opportunities for hardworking black miners in McDowell County. Things were so good that the editor of the Times, M.T. Whittico, stated that West Virginia was "a veritable Eldorado for the industrious Negro."44 Because of the quality of race relations and the number of opportunities available to African Americans, McDowell County quickly had the largest concentration of black labor in the coalfields. For instance, in 1908, 11,483 miners toiled in the county's coal industry. Of this total, 43.1 percent were black. According to the 2000 census, McDowell County still has a large concentration of

\footnotetext{
${ }^{43}$ Kenneth Bailey, “A Judicious Mixture: Negroes and Immigrants in the West Virginia Mines, 18801917," West Virginia History 34 (January 1973): 157-158; Howard B. Lee, Bloodletting in Appalachia: The Story of West Virginia's Four Major Mine Wars and Other Thrilling Incidents of Its Coal Fields (Morgantown: West Virginia University, 1969), 203-208; Ronald L. Lewis, Black Coal Miners in America: Race, Class, and Community Conflict, 1780-1980 (Lexington: University Press of Kentucky, 1987), 148-149.

${ }^{44}$ Editorial, McDowell Times, September 22, 1916.
} 
black residents, about 11 percent, the highest in the state. In general, race relations continue to be good. ${ }^{45}$

The influx of African American miners was a reflection of the prosperity of the McDowell County coal industry. McDowell County grew for several other reasons. The state's vast mineral resources would encourage the economic growth of the state, the advancement of new technologies, and the demands of World War I led to the development of a unique way of life for residents of McDowell County. The coal companies built towns and various recreational and civic institutions which gave the people of the county a sense of cohesion the likes of which they had never experienced before. Although miners enjoyed material, the lack of political power created a sense of oppression caused by the actions of the operators. The reaction to this exploitation led to another source of community development based on common employment experiences. The new sense of community would be challenged during the 1920s, however, as economic crisis gripped the coal industry and, by 1929, the entire country.

\footnotetext{
${ }^{45}$ Sterling Spero and Abram Harris, The Black Worker: The Negro and the Labor Movement (New York: Columbia University Press, 1931), 217.
} 


\section{Chapter 2 \\ Depression, Recovery, Instability: The New Deal and McDowell Coal}

By the mid-1920s, the coal community that characterized society in McDowell County was well established, but confronted serious challenges. During the decade, coal companies faced an uncertain future as the industry suffered through a decade-long downturn; in the coalfields, the Great Depression began well before the stock market crash of October 1929. By 1932, conditions in McDowell County were among the worst in the nation, but would slowly improve after the election of Franklin D. Roosevelt in 1932, and the implementation of his New Deal reforms. The passage of the National Industrial Recovery Act (NIRA) and the authority given to the National Recovery Administration (NRA) to promulgate industrial codes of fair competition to stabilize the coal industry, resulted in a change in mining methods and relationships between miners and employers. Although it seemed that the NRA succeeded in bringing recovery to the coal industry immediately after the implementation of the coal codes, the agency ultimately failed to stabilize coal. The production and employment numbers for three representative mines in McDowell County, Olga number one in Coalwood, United States Coal and Coke number six in Gary, and Peerless Coal and Coke in Vivian, show that the coal industry went through another downturn in the late 1930s. ${ }^{1}$ Furthermore, the NIRA, with its support for collective bargaining, led to increased labor costs and encouraged companies to introduce machinery in an effort to protect their profitability. Although the McDowell mines did not mechanize to the

\footnotetext{
${ }^{1}$ The three mines used in this study represent different operational scales. Olga number one was a large operation. Peerless was a smaller, yet significant contributor to the McDowell economy. U.S. Coal and Coke was a subsidiary and captive mine for U.S. Steel and was, therefore, an entirely different kind of operation.
} 
extent that mines in traditional union coalfields did, the NRA set the precedent to encourage the adoption of machinery, which as a core component of deindustrialization eventually displaced many miners in McDowell County.

By the mid-1920s, the McDowell County coal industry held an important place in the markets of the world. Migrants who poured into the region to find work in the coal mines settled into the company towns that dotted the landscape where coal mining had become a way of life. On the surface it appeared that the economy of the county was strong, but a depression in the bituminous coal industry began in 1919 and remained unstable. The instability resulted from the very cause of the expansion during World War I. The needs of the war led to the opening of new, often marginal mines, and after the war demand for coal plummeted. As a result, many mines closed and coal prices were volatile. Because of the importance of mining to West Virginia, the problems in the coal industry set the stage for the Great Depression well before $1929 .^{2}$

The problems facing the national coal industry during the 1920 s were momentous. The supply of coal increased while demand fell with the pull back of wartime industries, but there were other reasons for the drop as well. Increased output and productivity of the oil and natural gas industries made oil and gas cheaper alternatives to coal in many regions of the country. The invention of the diesel engine, for instance, led to oil replacing coal as the preferred fuel for the railroads. Demand for

\footnotetext{
${ }^{2}$ Charleston Gazette, 16 September 1929; Thomas Longin, "Coal, Congress, and the Courts: The Bituminous Coal Industry and the New Deal," West Virginia History 34 (January 1974): 101; Jerry B. Thomas, An Appalachian New Deal: West Virginia in the Great Depression (Lexington: University Press of Kentucky, 1998), 8.
} 
coal shrank and as the growth rate of consuming industries grew slowly, it became difficult for mines to sell coal at a price which covered production costs. ${ }^{3}$

The labor strife that resulted from continued UMWA efforts to organize nonunion fields added to the problems facing the coal industry in the 1920s. Labor strikes, external competition, and divisive competition among state operators led to chronic losses for the operators and frequent failures of mines. To prevent bankruptcy, operators either reduced wages or adopted labor-saving machinery. The reduction of wages led to near starvation for many of the miners. Many smaller mines closed and left a multitude of miners out of work. About 14,000 miners lost their jobs between 1923 and 1929. For much of the decade, coal production continued to increase despite the problems in the industry, peaking at 144 million tons in 1927. Market forces, however, caught up with the coal industry in West Virginia as demand and production began a consistent downward trend after $1927 .^{4}$

The future in West Virginia seemed bleak. When West Virginia became the leading coal producer in the nation in 1928, the state's newspapers cheered the news, despite the obvious downturn in the entire industry. The Charleston Gazette took an optimistic approach when it declared that downward trends in the industry "cannot mean anything but that the coal business is readjusting itself and lopping away the

\footnotetext{
${ }^{3}$ Harold Barger and Sam H. Schurr, The Mining Industries, 1899-1939: A Study of Output, Employment, and Productivity (New York: National Bureau of Economic Research, 1944; reprint, New York: Arno Press, 1972), 78 (page citations are to the reprint edition); James P. Johnson, The Politics of Soft Coal: The Bituminous Industry from World War I through the New Deal (Urbana: University of Illinois Press, 1979), 122; Longin, "Coal, Congress, and the Courts," 102.

${ }^{4}$ State of West Virginia, Annual Report of the Department of Mines (Charleston, 1927), 102; State of West Virginia, Annual Report of the Department of Mines (Charleston, 1929), 119.
} 
deadwood." The Clarksburg Exponent, on the other hand, took a realistic approach when it noted that in 1928 production declined, companies failed, and the numbers employed decreased. It was clear to the editors of the Exponent that coal was a sick industry and that the economy of West Virginia was on tenuous footing. ${ }^{6}$

The coal industry's production and employment trends in McDowell County followed the national patterns. The county's production totaled almost 22 million tons in 1927 , but just two years later had declined by almost one million tons. ${ }^{7}$ Employment declined as well, from 20,109 in 1926 to 18,558 in $1928 .^{8}$ By the eve of the economic collapse in 1929, the county's coal industry seemed to rebound from the industry-wide depression of the 1920s. Employment increased to 19,424 and production increased to almost 138 million tons. ${ }^{9}$ Individual companies also saw an improvement. Although the Annual Report of the Department of Mines for the state does not give employment figures for individual companies between 1929 and 1934, the increase in production numbers for both Peerless and U.S. Coal and Coke's number six mine between 1928 and 1929 suggests that, contrary to national trends, the state of the coal industry in McDowell improved during the late 1920s. ${ }^{10}$ National economic problems, however,

\footnotetext{
${ }^{5}$ Charleston Gazette, 16 September 1929.

${ }^{6}$ Ibid.; Ellis W. Hawley, The New Deal and the Problem of Monopoly: A Study in Economic Ambivalence (Princeton, NJ: Princeton University Press, 1966), 205-206; Stanley Vittoz, New Deal Labor Policy and the American Economy (Chapel Hill: University of North Carolina Press, 1987), 51-52; Thomas, An Appalachian New Deal, 8-9.

${ }^{7}$ State of West Virginia, Annual Report (1927), 101; State of West Virginia, Annual Report (1929), 84.

${ }^{8}$ State of West Virginia, Annual Report of the Department of Mines (Charleston, 1926), 192; State of West Virginia, Annual Report of the Department of Mines (Charleston, 1928), 170.

${ }^{9}$ State of West Virginia, Annual Report (1929), 84, 95.
} 
would destroy the gains made by the industry and seriously harm the lives of the miners of McDowell County.

The crash of the stock market on October 29, 1929, ushered in a period of economic hardship unknown before in the United States, a period later called the "Great Depression." The economic collapse hit the entire country; banks closed, men and women lost their jobs, and a general sense of hopelessness settled upon the landscape. The slump of the 1920s had depressed the coal industry enough to make collapse inevitable after the crash of October 1929. Coal production fell 40 percent from 1929 to 1933. This drop in production, in and of itself, would not have been a problem if market demand had remained steady. But demand fell proportionally to the drop in production. As a result of the drop in both demand and production, wages fell significantly. Coal families faced economic hardships never seen before and created a sense of despair among the county's miners and their families. During the Depression, thirty of the county's ninety mines closed, almost 3,000 of McDowell's miners lost their jobs, and the remaining 16,000 worked only a few days per week. At best, a mining family could barely expect to survive on the reduced wages miners earned. At worst, a family faced the prospect of starvation and homelessness because there were no other employment opportunities available. Migration was not an option because jobs were scarce throughout the nation. ${ }^{11}$

\footnotetext{
${ }^{10}$ State of West Virginia, Annual Report (1928), 74-75; State of West Virginia, Annual Report (1929), 69-70.

${ }^{11}$ State of West Virginia, Annual Report (1929), 85, 118; State of West Virginia, Annual Report of the Department of Mines (Charleston, 1933), 75, 112; James S. Olson, "The Depths of the Great Depression: Economic Collapse in West Virginia, 1932-1933," West Virginia History 38 (April 1977): 223.
} 
As the Depression deepened in West Virginia, conditions were among the worst in the United States. Some 33,000 coal jobs disappeared as coal production fell from 144 million tons in 1927 to 84 million tons in $1932 .{ }^{12}$ Throughout the state, coal families lost their homes and became trapped in a cycle of despair. Relief for the suffering families became a top priority for local government officials who exerted every effort to provide relief for the suffering citizens of West Virginia in the face of seriously inadequate budgets to deal with the crisis. Every county dealt with the crisis in its own way, because fiscal conservatives who controlled the state legislature refused to assist the counties in their relief efforts. In McDowell, the county court met in November 1930 to discuss the worsening problem. After the meeting, the court asked the county's coal operators to divide available work among each family head so that everyone had an opportunity to work each week. The commissioners further argued that "it should be the responsibility of the large coal companies to prevent suffering in their camps whenever possible," and urged the companies to cooperate with charitable organizations. ${ }^{13}$ Some government officials believed that relief efforts were not necessary and might create economic dependency. Conservative policy-makers argued that if given relief people would quit working and cease to contribute to society. Every relief organization struggled with the problem of identifying those who were only interested in a "free ride." In McDowell, the county court sought assistance from the coal companies in identifying those worthy of assistance. Identification by the coal

\footnotetext{
${ }^{12}$ State of West Virginia, Annual Report (1927), 102; State of West Virginia, Annual Report of the Department of Mines (Charleston, 1932), 89; West Virginia Commissioner of Labor, $21^{\text {st }}$ Biennial Report of the Department of Labor (Charleston, 1933), 6.

${ }^{13}$ Welch (WV) Daily News, 6 January 1931.
} 
operators of needy applicants, who were willing to work given the chance, resulted in a denial of aid to loafers so the assistance could go to those who were truly worthy. ${ }^{14}$

As the economic crisis deepened in McDowell County, coal mining employment continued to decline and required companies to dismiss thousands of miners. Coal mining employment decreased in the county from 19,424 in 1929 to 16,098 in 1932. ${ }^{15}$ Peerless and U.S. Coal and Coke felt the economic crunch as well. Production at Peerless declined from 358,149 tons in 1929 to 146,841 tons during the height of the Depression in 1932. ${ }^{16}$ Although the miners employed in the Peerless mines at Vivian suffered tremendously during the Depression, the economic crisis of the 1930s affected the miners working at U.S. Coal and Coke's number six mine even more. Production at number six fell from 904,580 tons in 1929 to 278,638 tons in 1931. By 1932, U.S. Coal and Coke decided to close the number six mine, resulting in the displacement of hundreds of miners. ${ }^{17}$ The widespread poverty caused by unexpected layoffs hindered relief initiatives. County and private relief efforts could not help everyone in need, many of those who usually contributed to relief efforts quickly found themselves on the relief rolls. Conditions deteriorated to such desperate levels that county officials petitioned the state for funding to cover the growing requests for assistance. The problems in McDowell touched all aspects of life. Six thousand

\footnotetext{
${ }^{14}$ Bluefield (WV) Daily Telegraph, 9 November 1930; James T. Patterson, The New Deal and the States: Federalism in Transition (Princeton, NJ: Princeton University Press, 1969), 26-27.

${ }^{15}$ State of West Virginia, Annual Report (1929), 118; State of West Virginia, Annual Report (1932), 120.

${ }^{16}$ State of West Virginia, Annual Report (1929), 69; State of West Virginia, Annual Report (1932), 71.

${ }^{17}$ State of West Virginia, Annual Report (1929), 70; State of West Virginia, Annual Report of the Department of Mines (Charleston, 1931), 70.
} 
children of the county could not attend school due to a lack of clothing and books, sanitation and nutrition diminished for those who still lived in coal camps, and an alarming growth in the incidences of typhoid, diphtheria, and dysentery struck McDowell County coal towns. ${ }^{18}$

As the election of 1932 approached, there was no end in sight for the economic crisis. The Republican administration of Herbert Hoover supported traditional relief programs, those provided by private individuals and charities. It was clear that this approach was not working and in the election of 1932 the voters of West Virginia supported the Democratic presidential nominee, Governor Franklin D. Roosevelt of New York. The election of the Democrats in 1932 demonstrated that West Virginians had accepted the necessity of government relief programs. Riding the tidal wave of discontent, Roosevelt immediately began to change the way in which the country assisted those affected by the economic collapse. ${ }^{19}$

The passage of the National Industrial Recovery Act (NIRA) in 1933 influenced industry in several different ways. The NIRA set forth a general procedure for the formation of industrial wage and price codes. The establishment of the industrial codes fell to the National Recovery Administration (NRA). The NIRA did not, however, provide guidelines as to the type of provisions to be found in the codes. The only specifics required to be included in the codes were those dealing with labor. Labor and industry representatives negotiated the rest of the industrial codes. Section 7 of the NIRA stipulated that the codes would set minimum wages, maximum hours,

\footnotetext{
${ }^{18}$ Thomas, An Appalachian New Deal, 115-116.

${ }^{19}$ Ibid., 69.
} 
appropriate working conditions, outlawed yellow-dog contracts, and guaranteed the right of labor to collective bargaining. ${ }^{20}$ Businesses which accepted the industrial code agreements would be exempt from antitrust laws and widespread acceptance of the codes served as a stabilizing agent for the coal industry. ${ }^{21}$

The NIRA was significant because it was the first peacetime attempt by the national government to regulate industry. During the latter part of 1933, representatives of various industries promulgated codes of fair practice under the direction of the NRA. The negotiations were tense in most industries, however, because business and labor representatives had different ideas concerning the solutions to the nation's economic problems. Business leaders wanted to protect business, government officials wanted to protect competition, and organized labor wanted to protect the interests of workers. The NRA ultimately failed because it tried to accommodate too many contradictory interests. Also, the federal government did not have the resources to regulate business adequately so that was left to the trade associations. $^{22}$

\footnotetext{
${ }^{20}$ There were many types of yellow-dog contracts, but the most commonly-used one, which companies required employees to sign, stated that an employer would not employ a member of a union and that the employee would neither join a union nor aid in the organization of a union.

${ }^{21}$ Robert F. Himmelberg, The Origins of the National Recovery Administration: Business, Government, and the Trade Association Issue, 1921-1933 (New York: Fordham University Press, 1976), 207.

${ }^{22}$ James A. Hodges, New Deal Labor Policy and the Southern Cotton Textile Industry, 1933-1941 (Knoxville: University of Tennessee Press, 1986), 5; James P. Johnson, "Drafting the NRA Code of Fair Competition for the Bituminous Coal Industry," Journal of American History LII (December 1966): 521-540; Hugh S. Johnson, The Blue Eagle from Egg to Earth (New York: Doubleday, 1935; Reprint, New York: Greenwood, 1968), 240-243; Irving Bernstein, Turbulent Years: A History of the American Worker, 1933-1941 (Boston: Houghton Mifflin, 1970), 40-50; Longin, "Coal, Congress, and the Courts," 105.
} 
The coal industry found the task of enacting the industrial codes difficult because mining and wage standards varied in all thirty-three mining states, and so did the degree of unionization, further impeding the future negotiations of the coal code. In an effort to protect their interests, many coal companies submitted versions of the coal code that would be sympathetic to their interests. The administration believed that the best way to resurrect industry in the United States was through national coordination, therefore the federal government thwarted all efforts to submit regional codes. Moreover, General Hugh Johnson, head of the NRA, was generally ignorant of the problems confronting the coal industry, and that retarded the debates on a code of fair competition for the industry. The negotiations on the code broke down when Johnson, on August 22, 1933, stated that he would clarify section 7A. The southern operators believed that Johnson threatened their interests and immediately refused to bargain further. There was also dissension among the operators. Because the Illinois and Indiana coal fields were unionized, it was very difficult to get the operators to agree among themselves on anything. Southern operators wanted regional codes in order to protect their interests. ${ }^{23}$ Northern operators and the union argued for a single national code in order to achieve parity and unionism in the South. General Johnson worked diligently to coerce the industry representatives to sign the code, but the debates dragged on through the summer. The UMWA insisted that the operators' delay in negotiations was an effort to retain the old system in the coal industry. In the United Mine Workers Journal of September 15, 1933, the union argued that the negotiated

\footnotetext{
${ }^{23}$ Southern operators in this instance describes the operators in the southern United States, primarily in Appalachia.
} 
code was fine and that the objection of the operators was nothing more than an effort to continue exploiting the miners. The final code would, in the UMWA's opinion, stabilize the coal industry. Finally, President Roosevelt became involved in the process on September 14, 1933, when he declared that if the representatives did not come to an agreement within twenty-four hours he would impose one. The committee reached agreement one hour before the deadline, but the pact would prove to be a very fragile one. $^{24}$

The code was a compromise between operators of union fields and operators of non-union fields, because it required a national board, pursuant to the wishes of the union operators, yet the code also allowed for regional boards to handle disputes, a demand of the non-union operators. The code provided for five regional divisions and fifteen wage districts. A national board governed the industry and each division had its own labor board to handle disputes. Together with the code agreements, the committee also signed the Appalachian Agreement on September 21, 1933. The Appalachian Agreement was a labor compact that gave the code national recognition. The agreement provided for an eight-hour day and forty-hour week, the right of the miners to choose their own checkweighmen, the end of compulsory purchases at the company store, the abolition of scrip, the end of mandatory company housing, the institution of a minimum age of seventeen to work in the mines, and the right to collective

\footnotetext{
${ }^{24}$ K.M. Simpson to S.A. Wender, September 9, 1933, Records of the National Recovery Administration (NRA), Record Group (RG) 9, Box 12, National Archives (NA), College Park, MD; Charleston Gazette, 10 September 1933; United Mine Workers Journal (hereafter cited as UMWJ), 15 September 1933; New York Times, 18 June, 10 July, 11 July 1933; Johnson, The Blue Eagle, 150; Bernstein, Turbulent Years, 44.
} 
bargaining. ${ }^{25}$ The right to collective bargaining in the Appalachian Agreement was significant because it was the first time that the non-union operators agreed to recognize this right. $^{26}$

The NIRA aided the UMWA in its efforts to organize the southern West Virginia coalfields. Section 7A gave a languishing organization needed momentum to conduct a largely successful organizational drive in southern West Virginia. The success of the membership drive did not derive solely from the changes instituted by the NIRA. Even before the passage of section 7A, John L. Lewis, president of the union, began planning the most extensive unionization movement in West Virginia history. During the drive, many organizers told the crowds, "the president wants you to join the union." 27 The tactic of invoking the president seemed to make joining the union synonymous with patriotism, yet when asked, organizers admitted that they meant the president of the union. Before the organization drive by the UMWA, wages in southern West Virginia were as low as $\$ 1.50$ a day. After the Appalachian Agreement was signed, wages were about $\$ 4.20$ a day, only about fifty cents below the minimum for the traditionally unionist Central Competitive Field. ${ }^{28}$ Furthermore, the

\footnotetext{
${ }^{25}$ Prior to the 1930 s, companies paid miners by the ton. Checkweighmen observed the weighing of the coal to insure that the companies paid miners accurately for the amount of coal mined. Scrip was a form of pay that companies often gave miners in lieu of legal tender. Scrip could only be redeemed at the company store, giving companies the opportunity to charge higher prices and increase profits.

26 “Appalachian Agreement," Records of the NRA, RG 9, Box 13, NA; New York Times, September 8 , 1933; Coal Age 38 (September 1933): 317; Paul Salstrom, Appalachia's Path to Dependency: Rethinking a Region's Economic History (Lexington: University Press of Kentucky, 1994), 87-88; Johnson, The Blue Eagle, 159-160.

${ }^{27}$ Thomas, An Appalachian New Deal, 93.

${ }^{28}$ The Central Competitive Field encompassed the bituminous coalfields in Illinois, Indiana, Ohio, and Pennsylvania.
} 
UMWA saw the code as the final solution to the problems facing miners and their families. In the first issue of UMW Journal published after the code was signed, the union stated: "This gigantic achievement gives to the bituminous coal industry a code of fair competition and sound business and industrial principles that should prove to be the salvation of the industry and all who are interested in it. ${ }^{29}$ Not only did the new contract cover every mining field in which the UMWA enjoyed some success in previous years, it also included non-union fields such as McDowell County where the union had previously been forbidden to enter. Therefore, changes resulting from the NRA produced a higher degree of labor stability in the coal industry, or so it seemed. ${ }^{30}$ Not every mine, however, came under the auspices of the NRA. Originally, the NRA did not apply to "captive mines," such as those of U.S. Coal and Coke, because they did not compete in the commercial coal market. All of the coal mined at U.S. Coal and Coke mines went to its parent company, U.S. Steel, but miners employed at captive mines wanted access to a fair contract too. After an unauthorized wildcat strike at captive mines in western Pennsylvania, most of the steel companies agreed to follow the provisions of the bituminous coal code in their mines. United States Coal and Coke resisted the code more than other captive mine companies. In December 1933, two months after most of the steel industry agreed to follow the code, the UMWA District 17 published a letter that had been sent to McDowell miners at the Gary mines of U.S. Coal and Coke. In the letter, the union called on the miners to make a decision about

\footnotetext{
${ }^{29} U M W J, 1$ October 1933.

${ }^{30}$ Ibid.; Melvyn Dubofsky and Warren Van Tine, John L. Lewis: A Biography (New York: Quadrangle, 1977), 184-186; Bernstein, Turbulent Years, 41; Longin, "Coal, Congress, and the Courts," 106; Salstrom, Appalachia's Path to Dependency, 87-88.
} 
accepting the UMWA as their bargaining agent without fear of reprisal from the companies. The federal government, under the auspices of the NRA, would ensure that the company permitted the miners to organize. The company continued using force to keep the union out of Gary, however. In April 1934, a letter from W.O. Stuart, president of the UMWA local at Gary, appeared in the Journal. Stuart noted that the organizing process was extremely difficult at Gary, and "two union men were beaten with blackjacks by company thugs. ${ }^{, 31}$ Stuart lamented about the lack of federal support for the unionization movement at Gary, yet ended the letter by restating the union men's resolve to organize the mines at Gary. ${ }^{32}$

The workers at U.S. Coal and Coke eventually succeeded in gaining recognition for their local union without a long work stoppage. Miners at other mines in McDowell were not as lucky, though. After the signing of the bituminous coal code and the Appalachian Agreement, miners at the Fordson mine at Twin Branch organized under the auspices of the UMWA. The management at Fordson refused to negotiate with the union; rather than allowing the UMWA to gain a foothold at their mine, management of the Twin Branch mine closed their operation in January 1934. The company asked all miners to turn in all equipment owned by the company and report for final settlement of wages. The mine stayed closed for at least six months. In July, a letter appeared in the UMW Journal from the recording secretary of the Local at Twin Branch which

\footnotetext{
${ }^{31} U M W J, 15$ April 1934.

${ }^{32}$ Ibid., UMWJ, 15 October 1933, 15 December 1933.
} 
suggested that the company was considering reopening the mine, but it is unclear whether the company agreed to negotiate with the union miners of Twin Branch. ${ }^{33}$

On the state level, the NRA had many economic, social, and political consequences. In keeping with the spirit of the NRA, the state government of West Virginia struck several blows to the old order. In October 1934, Governor Herman Kump ordered Sheriff Maginnis Hatfield of McDowell County to disarm and disband the 195 deputies who had public authority, but were paid and controlled by the operators. In 1935, the state legislature abolished the mine-guard system, approved a prevailing wage-rate law, amended workmen's compensation, and provided compensation for victims of silicosis. Within a five-year period, it seemed that the miners in West Virginia were freed from the yolk of oppression by the operators. ${ }^{34}$ Despite the apparently harmonious relationship between labor and industry in West Virginia, defenders of the old order did not disappear. At the twenty-seventh annual meeting of the West Virginia Coal Mining Institute, for instance, William Beury, vice-president of the Algoma Coal Company, defended practices condemned by the NRA. Beury argued that it was necessary for coal operators to be patriarchs for their miners. Companies required camps because the areas where coal could be found were so desolate that adequate housing did not exist. After the coal industry expanded, the camps kept the workers satisfied. Beury argued that payment in scrip protected families because wages could be used for liquor or labor racketeers (i.e. union organizers). Beury continued the tradition of "paternalism" by arguing that miners

\footnotetext{
${ }^{33} U M W J, 15$ February 1934, 15 July 1934.

${ }^{34} U M W J, 11$ November 1933.
} 
either would not, or could not, provide for their families. Beury also believed that mine guards were superior to elected officials because they were controlled by the company. ${ }^{35}$ Other operators agreed with Beury's assessment; some decided to use traditional methods in an effort to ensure the survival of the open-shop. A miner from Welch told the UMWA that although organization of McDowell County was almost complete in November 1933, the Baldwin-Felts agents continued to operate in the county. ${ }^{36}$ The "gunmen," as the miner called them, tried to confuse the workers of McDowell by circulating false contracts. The operators hoped that the confusion over the false contract would result in miners striking against the true UMWA contract and breaking up their local unions. Although some miners struck against the contract, union efforts to explain the situation kept most workers on the job. ${ }^{37}$

Was the coal code successful in relieving unemployment and stabilizing the industry? Some argued that the code did little to help workers. The Progressive Miners of America objected to the code, because the organization contended that the code failed to help the unemployed because it did not allow work-sharing between employed and unemployed miners. ${ }^{38}$ Although the Progressive Miners had little influence in the creation of public industrial policy, its opposition served as a benchmark for further and future opposition to the NRA and the coal code.

\footnotetext{
${ }^{35}$ The companies hired private security forces, known as the mine guard system, in an effort to keep the peace and the union out.

${ }^{36}$ The Baldwin-Felts company provided mine guards for many coal companies in southern West Virginia.

${ }^{37}$ William Beury, "The Social Aspects of Coal Mines," in Proceedings of the West Virginia Coal Mining Institute, Twenty-Seventh Annual Meeting, Bluefield, West Virginia, December 5-6, 1933 (Morgantown, 1933), 63-77.

38، Objections by the Progressive Miners of America to Code," Records of the NRA, RG 9, Box 14, NA.
} 
Within a year after the promulgation of the coal code, the agreement reached in 1933 began to fall apart. The differences in local conditions that hindered the original negotiations recurred with efforts to modify the original code in order to allow parity within the industry. For example, in 1934 operators from Alabama, western Kentucky, and Tennessee, sought relief from the minimum day rates included within the code, because they felt that only by amending the code could operators from regions where local conditions might increase production costs compete in the market. The NRA agreed to pass some amendments, which particularly entailed increases in tonnage and piece work rates. While this action aided some portions of the coal industry as with the original code, operators in other regions, such as West Virginia, argued that the government unfairly discriminated against them and did not allow for fair competition. In public comment on the proposed amendment before it passed, H.R. Hawthorne, representing the Smokeless Operators Association of southern West Virginia, argued that increasing piece work rates was illegal and unethical to the concepts of NIRA and would "secure the maintenance of the existing lack of parity in certain districts." ${ }^{39}$ Whatever the issue, local considerations hindered the federal government's efforts to ensure fairness in industry. ${ }^{40}$

Even the UMWA eventually turned against the NRA. By early 1935, the union argued that the NRA had failed because it did not provide adequate relief for the unemployed. Both UMWA President John L. Lewis and American Federation of Labor

\footnotetext{
${ }^{39}$ H.R. Hawthorne, "Comments on proposed Amendment to Bituminous Coal Code for increasing piece work rates," Records of the NRA, RG 9, Box 13, NA.

40"'Hearing for the Modification of Bituminous Coal Code, April 9-11, 1934," Records of the NRA, RG 9, Box 12, NA; Smokeless Operators Reports to the NRA, Records of the NRA, RG 9, Box 12, NA.
} 
President William Green argued that the only solution to the unemployment problem was a thirty-hour week. Under the codes, there were no limits on the number of hours employees could work. The codes only retained the provisions for an average fortyhour week over a one-year period. Without some method to share available work, organized labor believed that the effort to take workers off relief rolls and back onto the job fell far short of its goals. ${ }^{41}$

The NRA failed to address a number of problems common to the coal industry. Overproduction was the most serious of these difficulties. Price increases exacerbated overproduction by giving the small operators incentive to open marginal mines. The reduction in hours by the NRA increased hourly wages, leading to a large increase in the cost of labor. As a result, many small operators realized that their marginal mines could not produce the amount of capital required to meet production costs. Smaller operations which relied on hand mining (mining coal without any mechanical aid) faced an uncertain future. Because of the higher labor costs, larger operators began to strip mine and to use mechanical loaders in the underground mines. Mechanization, once begun, intensified until machines eventually replaced most of the underground miners. $^{42}$

What machines affected coal miners in the 1930s? As with most issues in the coal industry, the type of machinery used depended heavily on locale. Some of the unionized fields, such as those found in Illinois and other Midwestern states, instituted

\footnotetext{
${ }^{41} U M W J, 15$ February 1935.

${ }^{42}$ Winco-Block Coal Company to Wayne P. Ellis, 24 March 1934, Records of the NRA, RG 9, Box 13, NA; Johnson, Politics of Soft Coal, 191.
} 
mechanical coal loaders during the depression years of the 1920s. Mechanical loading machines varied by design, but most included gathering arms that swept the loose coal onto a conveyor. The southern West Virginia coalfields labor costs had been so low that coal operators could profitably mine coal with less advanced methods. The most common machinery used in McDowell County mines were undercutters. Undercutters used a chain blade to notch the coal at the base of the seam, thus relieving the miner of the painstaking job of cutting the coal at the base of the seam by hand. Although the use of undercutters increased during the 1920s, most McDowell mines did not take advantage of the machinery available on the market. For most of the 1920s, Peerless mined a majority of their production by hand. U.S. Coal and Coke, in contrast, used undercutters to produce most of their coal during the decade. There was one important reason for the more frequent use of machinery in U.S. Coal and Coke mines during the 1920s. U.S. Coal and Coke, more than any other operation in the county, led the way in research and development. In the early 1920s, Colonel Edward O'Toole spent considerable time working on building a machine that would improve efficiency and increase profits for the company. O'Toole claimed that he built the first machine that combined both the cutting and loading actions in one motion. Although the number six mine did not use the O'Toole machine, the company, as a result of O'Toole's passion for coal machinery, implemented undercutters at number six. ${ }^{43}$

\footnotetext{
${ }^{43}$ C.E. Lawall, I.A. Given, and H.G. Kennedy, Mining Methods in West Virginia (Morgantown: West Virginia University, 1929), 36-39; Coal Age 27 (28 May 1925): 783-87; Keith Dix, What's a Coal Miner to Do? The Mechanization of Coal Mining (Pittsburgh: University of Pittsburgh Press, 1988), 33; Curtis Seltzer, Fire in the Hole: Miners and Managers in the American Coal Industry (Lexington: University Press of Kentucky, 1985), 12-13; Crandall A. Shifflett, Coal Towns: Life, Work, and Culture in Company Towns of Southern Appalachia, 1880-1960 (Knoxville: University of Tennessee Press, 1991), 203.
} 
By the mid-1930s, the UMWA had entered into a national contract with the coal industry which set minimum labor costs. If a company wanted to lower its prices, it had to reduce costs of production by lowering wages rather than by employing cost efficient machines. New Deal policies alone, however, do not explain the spread of mechanization in the 1930s. Low interest rates and capital costs, an increase in the demand for coal in 1934 and 1935, the concentration of large-scale production in the larger mines, and the selection of machinery offered by the mine supply industry all aided the spread of mechanization. The decrease in interest rates and the increase in the demand for coal influenced operators to invest in the new machinery developed by the mine supply industry. Because production was concentrated in the larger mines which had the capacity to implement new machine technology, mechanization affected more miners in the 1930s than ever before. ${ }^{44}$

The onset of mechanization inevitably led to the loss of jobs. If anything could have stopped the mechanization movement, it was the UMWA, but the union, led by Lewis, supported mechanization because he believed that the survival of the coal industry required mechanization. As might be expected, the rank and file of the UMWA did not agree with this assessment. At the UMWA national convention in January 1934, a delegate proposed that the union oppose all mechanized mining. The delegate thought it was the union's place to protect the jobs of all members of the union. In response to the motion, Lewis shouted in protest, "You can't turn back the

\footnotetext{
${ }^{44}$ Dix, What's a Coal Miner to do?, 198-199.
} 
clock!"45 The motion died as a result of Lewis's opposition. Lewis favored mechanization because he believed that it would stabilize industry in the long run, and as a consequence, he had promoted mechanization for many years prior to 1934. In his book, The Miners' Fight for American Standards, Lewis elaborated on his view as early as 1925 that the values of the UMWA necessitated mechanization.

Fair wages and American standards of living are inextricably bound up with the progressive substitution of mechanical for human power. It is no accident that fair wages and machinery will walk hand in hand.... The policy of those who seek a disruption of the existing wage structure would only postpone mechanization of the industry and perpetuate obsolete methods. ${ }^{46}$

Lewis probably was correct in his assessment of the influence mechanization would have on the coal industry. Yet the miners, particularly the African American miners who lost their unskilled jobs to machines, had every right to be dismayed with the progress of mechanization. ${ }^{47}$

By looking at the statistics, can historians argue that the NRA succeeded in stabilizing industry and improving the lives of workers? The immediate aftermath of the institution of the coal code showed remarkable improvement in both statewide and countywide production. State coal production increased from 84 million tons in 1932 to 98 million tons in 1934, and McDowell County production showed just as impressive an increase, from 13 million tons in 1932 to 17 million tons in $1934{ }^{48}$

\footnotetext{
${ }^{45}$ Coal Age 39 (February 1934): 83; New York Times, 25 January, 26 January 1934.

${ }^{46}$ John L. Lewis, The Miners' Fight for American Standards (Indianapolis: Bell Publishing, 1925), 108.

${ }^{47}$ United Mine Workers of America, Proceedings, 1927 Convention (Indianapolis: Cornelius Printing Company, 1927), 215; Dix, 161.

${ }^{48}$ State of West Virginia, Annual Report (1932), 86-87; State of West Virginia, Annual Report of the Department of Mines (Charleston, 1934), 94-95.
} 
Individual companies also showed a significant improvement in business after the NIRA. The Olga number one mine (a renaming of Consolidation Coal Company's Coalwood mine after its acquisition by the Carter Coal Company) increased production in its first two years under Carter from 462,314 tons in 1933 to over one million tons the next year. Peerless improved its output to 311,863 tons and U.S. Coal and Coke reopened its number six mine and produced 413,773 tons in $1934{ }^{49}$ Therefore, by 1935 , most indicators showed that the coal industry seemed to be pulling itself out of the depression and was stable.

As the 1930s progressed, however, it became clear that the efforts of the Roosevelt administration to stabilize industry had mixed results. The coal industry in McDowell County, for instance, reached its highest level of production of the decade in 1936, when county mines produced more than 23 million tons of coal. After a slight decrease in production in 1937, the bottom dropped out again in 1938 when county production fell to 16 million tons. ${ }^{50}$ As with the economic collapse of the early part of the decade, miners suffered the consequences of another crisis within the coal industry. McDowell employment declined in one year, between 1937 and 1938, from 21,521 to 18,606. ${ }^{51}$ The miners most affected by the layoffs, however, seem to have been those employed by small, marginal mines. All three mines represented in this study showed increased employment between 1937 and 1938. Olga number one employed 952

\footnotetext{
${ }^{49}$ State of West Virginia, Annual Report (1933), 58; State of West Virginia, Annual Report (1934), 77-78.

${ }^{50}$ State of West Virginia, Annual Report of the Department of Mines (Charleston, 1936), 93; State of West Virginia, Annual Report of the Department of Mines (Charleston, 1938), 95.

${ }^{51}$ State of West Virginia, Annual Report of the Department of Mines (Charleston, 1937), 95; State of West Virginia, Annual Report (1938), 98.
} 
miners in 1938, up from 922 the year before. Peerless had an increase of fifteen miners, while U.S. Coal and Coke worked ninety-four more miners in $1938 .^{52}$

Why did only the smaller mines of McDowell County lay off workers during the late 1930s? The smaller mines did not have the resources necessary to compete with more prosperous companies. The realities of the coal industry during the late 1930s required mines to mechanize in order to produce enough coal to pay miners the higher wage scales required by the NRA codes. Olga number one used undercutters to mine all of its production since Carter acquired the mine in 1934. Peerless, by 1938 , undercut a majority of its coal, specifically 227,898 of its total production of 424,772 tons. ${ }^{53}$ The reason the companies that survived the economic decline of the late $1930 \mathrm{~s}$ could hire new miners was because of the very nature of the undercutting machine. Undercutters, like most early coal mining machines, aided the workers in their jobs and allowed for an increase in production. Under the room and pillar system of mining, prevalent in the southern West Virginia coalfields during the early twentieth century, miners controlled every aspect of the mining process for a certain area, or "room." Before the implementation of the undercutter, the miner had to undercut the coal seam, as well as blast the coal, load the coal, and make any necessary safety precautions. Because undercutters did not displace any miners, the machines allowed for an increase in both production and employment. ${ }^{54}$

\footnotetext{
${ }^{52}$ State of West Virginia, Annual Report (1937), 73-75; State of West Virginia, Annual Report (1938), 75-77.

${ }^{53}$ State of West Virginia, Annual Report (1938), 33-35.

${ }^{54}$ Dix, What's a Coal Miner to do?, 81-82, 183.
} 
In coalfields with a strong labor movement, the combination of the support for unionization by the federal government that began with the NRA and the support for mechanization by the union, contributed to the continued use of mechanical loading machines. Even before the creation of the NRA, operators in the Illinois coalfields worked with union officials to negotiate an agreement that would allow operators to mechanize without fear of union reprisal. The UMWA agreed to the proposal and, after ratification of the contract in 1928, Illinois mines began to mechanize their mines so that by 1933 machines loaded 58.9 percent of the underground coal in Illinois. By contrast, West Virginia companies only loaded 1.2 percent of their underground coal by machine in the same year. ${ }^{55}$ The increased wage rates mandated in the coal code increased reliance on loading technology. Even after the Supreme Court ruled that the NIRA was unconstitutional in 1935 and revoked the authority of the industry codes, federal influence was still at a level that kept operators from breaking agreements made with the UMWA in the aftermath of the NIRA. As a result, price competition resumed after the Supreme Court ruling, yet the decision did not cause wage competition.

Because of the reluctance of operators to break their contracts with the UMWA and the need to stay competitive in an uncertain coal market, operators increasingly looked to machinery in an effort to increase profits. ${ }^{56}$ Interestingly enough, the McDowell County coal industry did not prescribe use of mechanical loaders during the latter half of the 1930s. Because of its non-union tradition, McDowell County only began to use undercutters during the 1930s. It was not until the crisis of World War II

\footnotetext{
${ }^{55} \mathrm{Ibid}, 182-183$.

${ }^{56}$ Ibid., 198.
} 
and the consequent manpower strain placed on the United States, that McDowell County mines looked to mechanical loaders in an effort to meet the increased demand.

Although it failed to stabilize industry, the NRA caused many changes to McDowell County. Traditional paternalistic institutions collapsed in the many coal towns of the county. The NRA's support of unionism, however clandestine, led to union contracts in West Virginia that increased labor costs. Mechanization was the answer for operators looking to maximize profits and decrease production costs. Although the mechanization that resulted from the institution of NRA codes did not directly lead to the implementation of mechanical loaders, that would have displaced numerous miners, it set the precedent for the future use of machinery in the mines of McDowell. A vicious cycle thus began. During World War II, McDowell mines looked to mechanical loaders to meet demand. By the 1950s, a decline in demand caused by increased competition from alternative fuels led the companies to implement use of continuous mining machines, which combined the mining and loading processes in one step. Along with the continued reliance of McDowell County on the coal industry, the continuous miner would result in a massive displacement of West Virginia's workers and, with continued problems within the industry itself, the collapse of McDowell County's economy. 


\section{Chapter 3 \\ Deindustrialization and the Economics of Coal}

In 1964, the Governor's Council of Economic Advisors submitted a report to West Virginia Governor Wally Barron titled The Condition and Prospects of the West Virginia Economy. In this optimistic report, James Thompson, the principle author, noted that many indicators suggested an improvement in the overall economic condition of West Virginia. Despite the general improvement in the economic outlook for the state, Thompson stated that employment in the coal industry declined by almost 1,000 people between September 1962 and September 1963. Although decline in employment is an obvious negative, Thompson placed a positive spin on this development. In discussing the statistics, Thompson said, "However, the sharp, downward plunge in mining employment which characterized the 1950s has apparently been halted."1 There was some evidence for this optimism; between September 1961 and September 1963, the coal industry suffered a net loss of 200 jobs; for the previous two year period, the net loss was 11,600 jobs. $^{2}$

Overall, however, the optimism of the report was misplaced, particularly for the coal industry. For McDowell County in particular, traditionally a leader in coal employment and production, the 1960s was the decade in which the deindustrialization process first became evident. The economics of coal had become so perilous that companies were forced to cut production costs wherever possible. To stay competitive, the mining industry in McDowell implemented the latest technology in its operations,

\footnotetext{
${ }^{1}$ James Howard Thompson, The Condition and Prospects of the West Virginia Economy: Submitted to Governor W.W. Barron, December 6, 1963 (Charleston: The Governor's Council of Economic Advisors, 1963).

${ }^{2}$ Ibid.
} 
which resulted in a large decline in the number of employees needed in the mines. For example, between 1949 and 1986, the number of workers in the McDowell coal industry decreased from 21,058 to $2,859 .^{3}$

How is the experience of McDowell County similar to, and different from, the national trend of deindustrialization? As with disinvestment elsewhere, deindustrialization in McDowell County resulted in significant job loss and the destruction of the community. Job loss forced thousands of people from their homes and into new positions elsewhere. Despite this important similarity, deindustrialization in McDowell County was very different from national deindustrialization in two ways. First, because of the unstable nature of the coal industry, deindustrialization began at a much earlier time, the 1950s. Second, as a natural resource extraction industry, mines must be located where coal exists. As a result, runaway shops, operations that are moved elsewhere, were rare. This does not mean that mines stayed open, however. Many mines did close between 1950 and 1990, putting a significant number of miners out of work. The second way in which deindustrialization occurred in McDowell was through widespread mechanization. As market pressures cut into the profits of coal companies, managers made the conscious decision to cut labor costs by introducing machinery. As a result, machines displaced many more miners than mine closures, particularly between 1950 and 1970 .

As noted above, World War II placed West Virginia's coal industry at the top nationally in terms of production. War production, although very important, cannot

\footnotetext{
${ }^{3}$ State of West Virginia, Annual Report of the Department of Mines, 1949 (Charleston, 1950), 116-117; West Virginia Coal Association, Coal Facts, 1986 (Charleston, 1986), 43.
} 
explain the industrial preference for West Virginia coal alone. From the opening of the coalfields in West Virginia, three economic factors caused the growth of the West Virginia coal industry. First, with the completion of the railroads into the southern West Virginia coalfields in the late nineteenth century, the area's proximity to regional markets could easily be exploited. Second, favorable freight rates kept transportation costs low. Third, lower wage rates in the southern West Virginia coalfields ensured that the price of southern West Virginia coal would continue to be competitive with coal from other states. ${ }^{4}$

With the beginning of World War II in Europe in 1939, American industry needed to increase production to meet the potential threat of being drawn into yet another European war. As a result, coal production increased significantly as the coal industry attempted to meet the fuel demands of the war industries. Because of the increased demand, coal production in West Virginia rose to 165 million tons in 1944. At the end of the war, there was an expected decline in the demand for coal. Surprisingly, however, the national economy experienced a post-war boom, from which the coal industry benefited tremendously. Coal production reached an all time high of 174 million tons in 1947 . It seemed as if the coal industry could expect a bright future. ${ }^{5}$

\footnotetext{
${ }^{4}$ James Howard Thompson, Significant Trends in the West Virginia Coal Industry, 1900-1957 (Morgantown: West Virginia University Bureau of Business Research, 1958), 1; Wage rates in southern West Virginia remained low because the United Mine Workers did not permanently organize most miners in the region until the 1930s. For a discussion of the drive towards unionization in the region during the period of industrialization see, David Alan Corbin, Life, Work, and Rebellion in the Coal Fields: The Southern West Virginia Miners, 1880-1922 (Urbana: University of Illinois Press, 1981). For an account written primarily for a broader audience, see Lon Savage, Thunder in the Mountains: The West Virginia Mine War, 1920-21 (Pittsburgh: University of Pittsburgh Press, 1990).

${ }^{5}$ Thompson, Significant Trends, 2.
} 
Any optimism found in the coal industry soon proved to be misguided. After the high point of 1947, coal production varied until the early 1950s, when it declined precipitously. By 1955, coal production in West Virginia had fallen to 113 million tons, the lowest amount since the Great Depression of the early 1930s. There were several reasons for the collapse. First, the war had pushed coal demand to heights which could not be sustained by the industry. The coal industry is, by its very nature, volatile and extremely susceptible to outside factors. Second, coal's share of the fuel market declined rapidly in the years following World War II, from 47 percent to 32 percent between 1947 and $19566^{6}$

Why did coal's share of the energy market decline in the post-war period? The primary answer to this important question is that traditional customers of the coal industry began using natural gas and petroleum products as a source of fuel. By 1956, petroleum products accounted for 37 percent of the fuel market, up from 31 percent in 1940. The natural gas industry was even more successful during this period. Between 1940 and 1956, the percentage of the national energy market supplied by natural gas increased from 12 percent to 26 percent. Coal industry leaders recognized the threat to the industry as early as 1946. Coal Age, a leading industry journal, ran numerous articles discussing the competition with oil and gas in an attempt to determine a course of action and understand the problems facing the industry. One advantage natural gas has over coal is in transportation. Gas is, of course, less bulky than coal and is less expensive to transport to market. Although gas pipelines represent a large, initial

\footnotetext{
${ }^{6}$ Ibid., 2, 49; Curtis Seltzer, Fire in the Hole: Miners and Managers in the American Coal Industry (Lexington: University Press of Kentucky, 1985), 55.
} 
capital outlay, once a pipeline is built, transportation costs decrease significantly. Also, since a pipeline is one-way only there are no empty return trips to increase transportation costs. Another major advantage enjoyed by natural gas is its cleanliness and convenience. Gas can be piped directly to the customer and represents a much cleaner fuel source than coal. During the 1940s and 1950s, American businesses and households were willing to pay for this convenience. ${ }^{7}$

How did the increased competition from natural gas and oil affected coal's standing in important national markets? For the purpose of this study, coal markets are divided into six separate categories: electric utilities, steel and coke, other manufacturing, retail deliveries, railroads, and miscellaneous. Naturally, increased competition and efficiency from other fuel sources resulted in a decline in the demand for coal in four of the six categories. The most important change that developed in the post-World War II period was the decline of demand by railroads. In 1945, the railroads bought 22 percent of the national coal production. By 1950, railroad use accounted for 13 percent; by 1956, railroads used only 3.3 percent of the total coal production. $^{8}$ What accounts for this drastic decline? As with other industries, the railroads converted to other fuels, specifically diesel. To a large degree, the collapse of

\footnotetext{
${ }^{7}$ Coal Age 51 (Sept. 1946): 72-77; Thompson, Significant Trends, 49-50; Seltzer, Fire in the Hole, 55; Carroll L. Christenson, Economic Redevelopment in Bituminous Coal: The Special Case of Technological Advance in United States Coal Mines, 1930-1960 (Cambridge, MA: Harvard University Press, 1962).

${ }^{8}$ U.S. Department of Commerce, Historical Statistics of the United States, Colonial Times to 1970, part $1,590-591$.
} 
the railroad market, which had traditionally been a strong market for coal, shocked many within the industry. ${ }^{9}$

The other market in which coal lost ground in the post-World War II period was the retail market. The term retail, in this instance, primarily describes coal use for residential and commercial heating. In 1945, retail sales accounted for about 21

percent of the total U.S. coal production. As retail customers realized the advantages of alternative fuels, particularly natural gas, retail demand for coal dropped dramatically. By 1956, national retail deliveries totaled about 49 million tons, about 11 percent of the total. $^{10}$

Statewide, the coal industry went through trends similar to the national industry. Two separate surveys conducted by the West Virginia University Bureau of Business Research detected the trends found in the West Virginia coal industry between 1951 and 1956 when consumption of West Virginia coal declined significantly in the railroad and retail markets. Railroad deliveries accounted for 13.0 million tons in 1951, or 8.0 percent of the total West Virginia coal production. In 1956, the railroads consumed 5.0 million tons, 3.3 percent of the total. In retail, a similar, although not as drastic, trend developed during the post-war period. In 1951, retail consumption was at 18.9 million tons (11.6 percent). By 1956, the retail market used only 12.4 million tons $(8.2$

\footnotetext{
${ }^{9}$ Thompson, Significant Trends, 50; Christenson, Economic Redevelopment in Bituminous Coal, 82-83; Seltzer, Fire in the Hole, 55.

${ }^{10}$ Commerce Department, Historical Statistics, part 1, 590-591; Thompson, Significant Trends, 50; Christenson, Economic Redevelopment in Bituminous Coal, 84; Seltzer, Fire in the Hole, 55.
} 
percent). Thus, the two markets which showed a decline in demand nationally went through a similar drop in West Virginia. ${ }^{11}$

Although the news in the railroad and retail markets was not good for the coal industry in 1956, some markets increased in demand or remained stable in the post-war period. One market which continued to perform strongly for American coal was the steel and coke market. Nationally, coke plants and steel mills used 111 million tons of coal, about 25 percent of the national consumption. This national percentage remained relatively stable during the post-war period. In West Virginia, the steel and coke market remained the most important destination for state coal and actually increased somewhat. Between 1951 and 1956, consumption by the steel and coke market rose from 42.8 million tons to 46.5 million tons, an increase from 26.2 to 30.9 percent. $^{12}$

Along with the improvement in the steel and coke market, the bituminous coal industry enjoyed a major increase in demand from the electric utility market. In 1934, electricity used only 9 percent of national coal production. As the nation electrified, however, the fuel needs of the electric utilities increased as a result of the higher demand. From the end of World War II to 1956, the amount of coal burned to generate electricity more than doubled. As a percentage of the national total, the electric utilities consumed about 31 percent of the coal sold in 1956. The rise in demand by the electric utilities is particularly important because it partially offset the losses felt in the retail market. As more and more homes and businesses turned to electricity as a heating

\footnotetext{
${ }^{11}$ Thompson, Significant Trends, 51; James Howard Thompson, Markets and Marketing Methods of the West Virginia Coal Industry (Morgantown: West Virginia University Bureau of Business Research, 1953), 8.

${ }^{12}$ Thompson, Significant Trends, 51; Thompson, Markets, 8.
} 
source, the harm felt by the coal industry was minimized. The percentage of West Virginia coal used by the electric companies increased as well. In 1951, electric utilities consumed 22 percent of the state coal production, and by 1956 the percentage had increased to a little over 23 percent. Although the electric utilities only ranked in second place as a destination market for West Virginia coal (to steel and coke), the growth of the national coal market for electricity foreshadowed the importance electricity would play for West Virginia coal in the future. ${ }^{13}$

Between 1956 and 1963, the electric utility market finally took the lead in consuming West Virginia coal. During this period, the electric utility market was the only market which increased its use of West Virginia coal. The steel and coke market, which ranked as the most important destination for state coal in 1956, experienced a slight decline to 24 percent of total consumption, down from 25 percent. By contrast, the electric utility market share of state coal increased from 23 percent to about 33 percent. The most severe losses occurred in the railroad and retail markets, which was a continuation of the trend which began in 1951. By 1963, the railroad market had virtually disappeared, and retail accounted for only one-third of its 1951 amount. $^{14}$

The trends in the coalfields of southern West Virginia differed somewhat from the market trends in the rest of the state. During the period between 1951 and 1956, the southern coalfields experienced a substantial decrease in production. The only market that increased its consumption of southern West Virginia coal was the export market.

\footnotetext{
${ }^{13}$ Thompson, Significant Trends, 50-51; Christenson, 84-85; Thompson, Markets, 8.

${ }^{14}$ James Howard Thompson, The Changing Markets for West Virginia Coal, 1951-1963 (Morgantown: West Virginia University Bureau of Business Research, 1964), 6-9.
} 
From 1956 to 1961, the state of the coal industry in southern West Virginia became even worse as production decreased by four times the drop from 1951 to 1956. The primary reason for this significant decline was the total collapse of the export market. Combined with further declines in the other markets, the situation for the southern West Virginia coal industry in the early 1960s was perilous. From this low point, however, a revival of sorts began with the recovery of the export market. Coupled with the expansion of the utility market for southern West Virginia coal, the economic outlook for southern West Virginia seemed to be vastly improved. There were several reasons why southern West Virginia operators turned more to the utility market. First, electric power production had been increasing in the Southeast more than in any other area. Second, reductions in rail freight rates made it more profitable for operators to sell to the utilities. Before, operators focused more on the higher priced markets of steel-coke and exports because of transportation problems and thinner seams. Third, new seams had been opened in the early 1960s. Although the coal in the new seams were in the 12,000 to 13,000 B.T.U. range, which was low by regional standards, the heat from the coal from the new seams was still better than coal from most other fields. ${ }^{15}$

With the onset of the energy crisis in 1973, coal became an even more important source of energy, particularly for the electric utilities. In 1984, nearly 84 percent of the coal used in the United States went to generate electricity. Coal provided about 56 percent of all the electricity used in the country. Appalachian coal played an

\footnotetext{
${ }^{15}$ Ibid., 7-10.
} 
important role in meeting the nation's electric needs. About 41 percent of the coal burned to generate electricity was provided by Appalachian coal mines. ${ }^{16}$

There were several reasons for the growth of coal as an energy source.

Although prices played an important role in causing electric utilities to increase their use of coal, the primary reasons for the increased burning of coal for electricity was the question of supply. With the oil embargo of 1973, electric companies, and other domestic buyers, realized that American coal was a secure energy source. As a result of the energy crisis, oil fell to fifth place in the production of electricity during the mid1980s. ${ }^{17}$

Despite the major advantages of natural gas, its cleanliness and cost effectiveness, coal continued to dominate the electric utility market. Before 1974, electric utilities used natural gas to a large extent. However, with the onset of the energy crisis, numerous supply interruptions occurred with natural gas. The primary reason for these supply interruptions was not because of a decrease in productive capacity. Rather, federal pricing policies caused most of the supply problems with natural gas. The U.S. Federal Power Commission kept the price of natural gas sold in interstate commerce so low that a balance between supply and demand was impossible. Suppliers, in an effort to maximize profits, would either supply the intrastate market, which was outside the jurisdiction of the Federal Power Commission, or cut back supply, resulting in significant interruptions of gas to the electric utilities. With the

\footnotetext{
${ }^{16}$ Curtis E. Harvey, Coal in Appalachia: An Economic Analysis (Lexington: University Press of Kentucky, 1986), 33.

${ }^{17}$ Ibid., 34.
} 
recession of the early-1980s and the deregulation of natural gas in the mid-1980s, demand for natural gas declined even more. ${ }^{18}$

Of coal's competitors for the electric market, residual fuel oil has traditionally been the strongest. Residual fuel oil is the thick residue left behind when crude oil is refined into products such as gasoline. American oil refiners traditionally have sought to refine as much crude as possible, leaving little residual oil. Foreign producers, in contrast, usually found residual oil to be very profitable and produced higher quantities than American refiners. Until 1966, the American government had strict import quotas on residual oil. That year the government lifted the quotas on imports to many eastern states, which led to an increase of residual oil use in power plants. As with other petroleum products, the oil embargo of 1973 led to a decrease in residual oil use as electric companies reexamined their use of the fuel. As a result, coal continued to play an important role in providing for the nation's electric needs. ${ }^{19}$

With the onset of the nuclear age, and for some time thereafter, it seemed that nuclear power would provide a continually increasing amount of electricity. In 1984, 13.6 percent of American electricity was produced by nuclear power. However, controversies regarding environmental concerns, safety, and technical problems led to a decrease in new reactors. Although nuclear power did produce a large amount of electricity in some states, reactors were increasingly removed and not replaced as they wore out. As a result, coal and oil use increased in the electric industry. ${ }^{20}$

\footnotetext{
${ }^{18}$ Ibid., 37.

${ }^{19}$ Ibid., 37-38.

${ }^{20}$ Ibid., 38-39.
} 
Although the electric industry became the most important market for coal by the 1970s, the coal industry remained an industry characterized by boom and bust periods. The oil embargo of 1973 and the subsequent energy crisis led to an improvement in the prospects for the industry. By 1978, however, the country found itself mired in a recession. There was a worldwide decline in steel production, which dropped the demand for coal. Also, new air pollution limits forced power plants to search for a type of coal which produced a lower amount of sulfur. Generally, this need was met by coal mined in western fields. As the energy crisis subsided, falling oil prices also cut into the demand for coal overseas, further damaging the industry. ${ }^{21}$

With the pressures faced by coal companies from competition, managers sought ways to cut costs and prices. With many mines in southern West Virginia under a collective bargaining agreement with the United Mine Workers of America (UMWA), cutting costs by decreasing wages was not feasible. The only way companies could cut production costs was by cutting labor costs through increased efficiency, which meant the implementation of machinery. The mechanization of the coal industry in McDowell County began in earnest with World War II. The transformation to a mechanized industry did not occur quickly, however. Companies bought new technology in small quantities as new machines became available. Despite the slow pace of mechanization, the employment situation in McDowell County changed considerably as machines displaced many miners and prevented many young people from gaining employment in the mines.

\footnotetext{
${ }^{21}$ United States Congress Office of Technology Assessment, An Assessment of Development and Production Potential of Federal Coal Leases (Washington: United States Congress Office of Technology Assessment, 1981); Seltzer, Fire in the Hole, 167.
} 
Market competition was not the only reason for the increased reliance on mechanization in the coal industry. Coal companies began employing machinery well before the rise of oil and gas as competitors to coal. In the years following World War I, for example, the industry in West Virginia became more and more unstable. The operators in the Pocahontas coalfield of southern West Virginia defeated postwar organizing efforts by the UMWA. Coupled with the fact that West Virginia coal remained popular in commercial markets, due to its smokeless burning, the lack of union success encouraged the opening of new mines, which inundated the market with excessive amounts of coal. When prices began to drop in 1923, operators were hit hard. To prevent bankruptcy, operators reduced wages or used labor-saving machinery. The reduction of wages led to a near starvation existence for many miners. Smaller mines closed, leaving thousands of miners out of work. As a result, the entire mining community suffered the consequences of overproduction. ${ }^{22}$

As stated above, machines became important during the dark days of the early 1920 s because they held the promise of raising profits for the operators by accelerating the pace of mining and reducing labor costs. The first machines introduced in the early years of the twentieth century were undercutters. Undercutters, usually mounted on track, used a chain blade to notch the coal at the base of the seam, a job previously performed by hand. As early as 1915, undercutters produced 60 percent of West

\footnotetext{
${ }^{22}$ Jerry B. Thomas, An Appalachian New Deal: West Virginia in the Great Depression (Lexington: University Press of Kentucky, 1998), 8-9; Thomas Longin, "Coal, Congress, and the Courts: The Bituminous Coal Industry and the New Deal," West Virginia History 34 (January 1974): 101; Ellis W. Hawley, The New Deal and the Problem of Monopoly: A Study in Economic Ambivalence (Princeton, NJ: Princeton University Press, 1966), 205-206; Stanley Vittoz, New Deal Labor Policy and the American Economy (Chapel Hill: University of North Carolina Press, 1987), 51-52.
} 
Virginia's coal. Productivity rose from 3 to $4 \frac{1}{2}$ tons per man day as a result of the use of undercutters. ${ }^{23}$

The success of the undercutting machines was the first step in the long evolution of the use of coal mining machinery. As early as World War I, coal operators and industry analysts discussed ways to manufacture machines for coal loading. In addition to the obvious reason for implementing mechanical loaders, increasing the production rate of coal, some analysts agued that the control miners had over production under the traditional room and pillar method of mining impeded the production rate. $^{24}$ In 1918 E.N. Zern, editor at Keystone Publishing, presented a paper on loading machine technology to the Coal Mining Institute of America. Zern argued that the industry's labor problems caused mechanization. He did not know whether the problem was "due to the scarcity of labor, its indifference, or its antagonism," but "the fact that it exists is sufficient." 25

Zern's analysis is too simplistic to adequately explain the social and economic forces that contributed to the introduction of machinery in the coal-mining process. The effort to replace obsolete machinery actually preceded World War I and the labor problems caused by the war. The significance of Zern's argument is his reasoning behind the use of machinery. Zern contended that mechanization exemplified a

\footnotetext{
${ }^{23}$ Crandall A. Shifflett, Coal Towns: Life, Work, and Culture in Company Towns of Southern Appalachia (Knoxville: University of Tennessee Press, 1991), 203; Seltzer, Fire in the Hole, 12-13.

${ }^{24}$ The room and pillar method of mining divided the mine into different areas, leaving a miner in charge of an individual area. The miner controlled all aspects of the mining process, from cutting, blasting, and loading the coal to taking any necessary safety precautions. For a more in-depth discussion of the room and pillar system of mining see: Keith Dix, Work Relations in the Coal Industry: The Hand-Loading Era, 1880-1930 (Morgantown: West Virginia University, 1977).

${ }^{25}$ Keith Dix, What's a Coal Miner to do? The Mechanization of Coal Mining (Pittsburgh: University of Pittsburgh Press, 1988), 33.
} 
progression within the coal industry. ${ }^{26}$ In 1924 the industry journal, Coal Mine

Management, reported that there were twenty-seven mechanical loading machines that had been tested underground. Through manufacturers' advertisements and articles in trade journals, coal operators became aware of the advantages of mechanization and the numerous loading machines available. ${ }^{27}$

Early loading machines varied in many different ways. Conveyors had to be fed by hand, while other machines loaded the coal after it had been blasted from the face. Still other devices, forerunners of the modern continuous mining machine, mined and loaded coal in one motion. The only similarity among these early machines was that most of them used an electric-powered chain conveyor. As stated above, Colonel Edward O'Toole of the United States Coal and Coke Company claimed that he had developed and built the first "real" cutting and loading machine in the early 1920s. ${ }^{28}$ O'Toole told an industry journal in 1925 that his work on machinery lagged because of the "excessively low labor rates prevailing at the time.",29 O'Toole stated that the labor costs of the wartime era required some sort of labor-saving device. Working in the U.S. Coal and Coke machine shops, O’Toole devised a system that involved a cutting

\footnotetext{
${ }^{26}$ For a contemporary discussion of the "progression" within the coal industry, see Carter Goodrich, The Miner's Freedom: A Study of the Working Life in a Changing Industry (Boston: Marshall Jones Company, 1925), 103-156. Goodrich describes the progression in the coal industry as the creation of a factory system underground.

${ }^{27}$ Coal Age 25 (17 January 1924): 66-71; Coal Mine Management 3 (June 1924): 38; Dix, What's a Coal Miner to do?,33-34.

${ }^{28}$ The United States Coal and Coke Company was one of the most important companies in McDowell County. U.S. Coal and Coke was a subsidiary of the United States Steel Corporation and opened many mines in the Gary area. By 1923 the company had become the largest coal producer in West Virginia and would be central to the economy of McDowell County for many years.

${ }^{29}$ Mining Congress Journal 11 (June 1925): 301; Dix, 37.
} 
chain mounted on a long cutter bar that was used to cut and load simultaneously. In back of, and parallel to, the cutter bar was a conveyor that loaded the coal into a car. The interesting feature of this machine was that it did not require drilling and blasting, but rather it used the weight of the rock to crush the coal as it was cut. The broken coal fell onto the conveyor as the machine worked. The O'Toole machine required a longwall, retreating system layout in the mine instead of the traditional room and pillar layout. Miners worked long-wall rooms out to a distance of about 600 feet, with pillars of coal left between each room. Besides the pillars of coal, roof support was provided by hydraulic jacks and collapsible timber cribs. As mining progressed, miners removed the cribs set behind the jacks and allowed the roof to cave in. ${ }^{30}$

The O'Toole machine did not succeed in changing the way miners dug coal. Because the coal industry was firmly committed to the traditional room and pillar method of mining, O’Toole's system received little attention from the industry as a whole. The O'Toole machine, and other early mining and loading machines like it, can be considered the predecessors of the continuous mining machines, but they did not aid the evolution of mobile loaders, which changed room and pillar mining. ${ }^{31}$

Operators introduced loading machines after World War I, but in the years prior to 1933 , their use was confined to northern, union coalfields. After the passage of the National Industrial Recovery Act in 1933, machinery rapidly entered West Virginia. ${ }^{32}$

\footnotetext{
${ }^{30}$ C.E. Lawall, I.A. Given, and H.G. Kennedy, Mining Methods in West Virginia (Morgantown, West Virginia University, 1929), 36-39; Coal Age 27 (28 May 1925): 783-87.

${ }^{31}$ Mining Congress Journal 11 (June 1925): 301; Dix, What's a Coal Miner to do?, 35-38.

32 The National Industrial Recovery Act (NIRA) led to an increase in the use of machine loaders in mines primarily because of section 7A of the law, which guaranteed the right of labor to collective bargaining.
} 
For example, during that year, coal loaded by machines in West Virginia constituted less than one percent of total production; by 1940, however, the proportion had risen to over 70 percent. During this period of rapid expansion of mechanical loading, the favorite machine of the industry was one that could be moved from room to room and was adaptable to different mining conditions. Joseph Joy, a miner, invented such a machine. The Joy loader became synonymous with coal mechanization and became the most widely-used loader in the coal fields of McDowell County. ${ }^{33}$

Machinery did not hinder the coal industry in West Virginia prior to World War II. In 1934, for example, the state Department of Mines reported that of the 98 million tons of coal produced by the state, over 87 million tons were hand loaded into cars. None of the coal produced in 1934 was loaded by machine. Continued effects of the Great Depression, the lack of available capital, and the use of cheap labor explain why machinery was not being used in West Virginia mines in $1934 .^{34}$

Historians have disagreed over whether or not southern West Virginia waited too long to mechanize its mines. Richard Simon, for instance, has argued that West Virginia coal operators waited too long to automate because of "destructive competition" among the coal operators. Simon contended that competition delayed automation and that southern West Virginia operators harmed their position by refusing

\footnotetext{
As a result, labor costs rose and operators implemented machinery in order to decrease the costs of production.

${ }^{33}$ Coal Age 47 (February 1942): 66-68; Herbert R. Northrup, Organized Labor and the Negro (New York: Harpers and Brothers Publishers, 1944), 168; Dix, What's a Coal Miner to do?, 61-76.

${ }^{34}$ State of West Virginia, Annual Report of the Department of Mines (Charleston: 1940), 22; There was also a small amount of coal still being mined by hand in 1934, about ten million tons. Pick mining would not be eradicated until the start of World War II.
} 
to mechanize. In his work, Appalachia's Path to Dependency, Paul Salstrom debunked Simon's argument. Salstrom stressed that southern West Virginia would not have developed economically to the extent that it did if the people of the region had not been willing to mine coal for lower wages than did northern workers. Coal operators would not have been willing to enter southern West Virginia because of the high costs of transporting the coal out of the region. Mechanization came exactly when it should have, when operators could mine the coal more cheaply by using machinery. ${ }^{35}$

In the late 1930s, the beginning of another war in Europe encouraged increased production of war materiel in the United States. Higher production resulted in a significant rise in the amount of coal mined in West Virginia. By 1940, coal production in West Virginia grew to over 126 million tons. An expanded movement towards mechanization occurred during the period before the United States' involvement in World War II. In 1940 West Virginia miners loaded over 30 million tons of coal by machine. Both hand loading from machine-cut coal and hand mining decreased significantly by $1940 .^{36}$

During the wartime era, McDowell County's coal production followed the same patterns as the state's production. The mines of the Carter Coal Company in Coalwood and Caretta, for example, relied on machines to cut their coal, although miners still hand loaded the coal into cars. By contrast, the Peerless Coal and Coke mines in

\footnotetext{
${ }^{35}$ Paul Salstrom, Appalachia's Path to Dependency: Rethinking a Region's Economic History (Lexington: University Press of Kentucky, 1994), 72-73; Richard Mark Simon, "The Development of Underdevelopment: The Coal Industry and Its Effect on the West Virginia Economy, 1880-1930," Ph.D. Dissertation, University of Pittsburgh, 1978, 367-369, 392.

${ }^{36}$ State of West Virginia, Annual Report of the Department of Mines (Charleston: 1940), 22.
} 
Vivian were in the process of phasing out hand mining in $1940 .^{37}$ About half the company's production that year was still hand mined, the other half was mined by five cutting machines and hand loaded into cars. ${ }^{38}$

By 1940, neither coal company had made the move to mechanized loading. Peerless began incorporating cutting machines by this time. The absence of mechanized loading was also evident throughout the county. In 1940, about 80 percent of the county's coal production was cut by machine and hand loaded into cars. Hand mining was still responsible for a portion of county production in 1940. Almost 3 million tons of coal were hand mined in the traditional room and pillar method of mining. Less than 2 percent of the total production was loaded by machine, continuing the pattern seen within the entire state. ${ }^{39}$

\footnotetext{
${ }^{37}$ Hand mining was the most primitive form of mining. Miners would do everything by pick and shovel, including undercutting the face and loading the blasted coal.

${ }^{38}$ State of West Virginia, Annual Report of the Department of Mines (Charleston: 1940), 42-45.

${ }^{39}$ Ibid.
} 
Table 1. Production and Machinery at Selected McDowell County Coal Mines, 1940.

\begin{tabular}{|c|c|c|c|c|c|}
\hline & $\begin{array}{l}\text { Olga \#1 } \\
\text { (Coalwood) }\end{array}$ & $\begin{array}{l}\text { Olga \#2 } \\
\text { (Caretta) }\end{array}$ & Caretta & $\begin{array}{l}\text { Peerless } \\
\text { (Vivian) }\end{array}$ & $\begin{array}{l}\text { County } \\
\text { Totals }\end{array}$ \\
\hline $\begin{array}{l}\text { Cutting } \\
\text { Machines }\end{array}$ & 3 & 4 & 8 & 5 & 305 \\
\hline $\begin{array}{l}\text { Conveyors } \\
\text { (Loaders) }\end{array}$ & 0 & 0 & 0 & 0 & 85 \\
\hline $\begin{array}{l}\text { Machine } \\
\text { Loaders }\end{array}$ & 0 & 0 & 0 & 0 & 19 \\
\hline $\begin{array}{l}\text { Hand Mined } \\
\text { Production } \\
\text { (in tons) }\end{array}$ & 0 & 0 & 0 & 359,058 & $2,868,863$ \\
\hline $\begin{array}{l}\text { Machine } \\
\text { Loaded (in } \\
\text { tons) }\end{array}$ & 0 & 0 & 0 & 0 & $1,280,753$ \\
\hline $\begin{array}{l}\text { Loaded in } \\
\text { Conveyors } \\
\text { (in tons) }\end{array}$ & 0 & 0 & 0 & 0 & $2,062,869$ \\
\hline $\begin{array}{l}\text { Hand } \\
\text { Loaded (in } \\
\text { tons) }\end{array}$ & $1,647,047$ & $1,800,224$ & 332,322 & 353,882 & $19,466,892$ \\
\hline $\begin{array}{l}\text { Total } \\
\text { Production } \\
\text { (in tons) }\end{array}$ & $1,647,047$ & $1,800,224$ & 332,322 & 712,940 & $25,679,377$ \\
\hline
\end{tabular}

Source: State of West Virginia, Annual Report of the Department of Mines

(Charleston: 1940), 42-45.

The Japanese attack on Pearl Harbor spurred increased industrial activity in the United States, that in turn enhanced demand for coal. Despite the increase in the production of war materiel since the onset of the European war in 1939, the United States still was not fully mobilized for war production. The entrance of the United 
States into the war also led to a new, yet familiar problem, that of a labor shortage. The coal industry had suffered the effects of labor shortages during World War I and the shortages impaired the industry, but during World War II labor shortages were not as intense. As miners went off to war, coal companies needed to find ways to increase production with fewer miners. For one thing, the competition from oil and gas actually helped the coal industry by relieving the pressures the war effort placed on the industry. Another trend which aided the industry was mechanization. Mechanization allowed coal companies to increase production with fewer miners. For those mines that still used traditional methods of mining, there was a need to increase production and to mechanize in a timely manner. ${ }^{40}$

The problem facing the West Virginia coal industry in 1941 was the need to increase production by mechanizing its mines. From 1940 to 1944, the machine loaded portion of the state's production more than doubled. During the period from 1940 to 1944, hand mining was completely eradicated and coal loaded by hand, on either cars or conveyors, fell from about 76 percent to about 56 percent of the total production. In 1945, when statewide production fell slightly, the amount of coal loaded by machine actually rose. ${ }^{41}$

The loading of coal for the Carter mine portray the acquisition of the mechanical loaders. As noted in Table 2, the Carter mines, which had no mechanical loaders in 1940, had twenty among its three mines in 1945. At the two Olga mines in Coalwood and Caretta, about 88 percent of the total production was loaded by machine.

\footnotetext{
${ }^{40}$ Shifflett, Coal Towns, 199-206.

${ }^{41}$ State of West Virginia, Annual Report of the Department of Mines (Charleston: 1945), 12.
} 
Olga miners still loaded the remaining tonnage by hand, but the company began a major effort towards complete mechanization of the mining process. At Vivian, Peerless bought three mechanical loaders and three conveyors between 1940 and 1945. The movement towards complete mechanization at the Peerless mine began with the introduction of the new machinery. Miners only hand loaded a little over half the production at Peerless in 1945, the rest was either loaded by hand on conveyors or with mechanical loaders. Although lagging behind many of the other mines in McDowell County, Peerless also strove to mechanize in the early 1940s. In McDowell County as a whole, mechanization continued, yet still trailed the rest of the state of West Virginia. Miners loaded approximately 35 percent of the county's coal production by machine. Workers loaded the rest by hand, either on cars or conveyors. ${ }^{42}$

${ }^{42}$ Ibid., 42-43. 
Table 2. Production and Machinery at Selected McDowell County Coal Mines, 1945.

\begin{tabular}{|c|c|c|c|c|c|}
\hline & $\begin{array}{l}\text { Olga \#1 } \\
\text { (Coalwood) }\end{array}$ & $\begin{array}{l}\text { Olga \#2 } \\
\text { (Caretta) }\end{array}$ & Caretta & $\begin{array}{l}\text { Peerless } \\
\text { (Vivian) }\end{array}$ & $\begin{array}{l}\text { County } \\
\text { Totals }\end{array}$ \\
\hline $\begin{array}{l}\text { Cutting } \\
\text { Machines }\end{array}$ & 4 & 5 & 5 & 9 & 358 \\
\hline Conveyors & 0 & 0 & 0 & 3 & 124 \\
\hline $\begin{array}{l}\text { Mechanical } \\
\text { Loaders }\end{array}$ & 9 & 10 & 1 & 3 & 126 \\
\hline $\begin{array}{l}\text { Production } \\
\text { Mechanically } \\
\text { Loaded (in } \\
\text { tons) }\end{array}$ & 930,280 & $1,173,345$ & 0 & 235,196 & $8,728,591$ \\
\hline $\begin{array}{l}\text { Loaded on } \\
\text { Conveyors (in } \\
\text { tons) }\end{array}$ & 0 & 0 & 0 & 39,464 & $1,238,288$ \\
\hline $\begin{array}{l}\text { Hand Loaded } \\
\text { (in tons) }\end{array}$ & 246,106 & 7,041 & 294,018 & 333,996 & $15,019,443$ \\
\hline $\begin{array}{l}\text { Total } \\
\text { Production } \\
\text { (in tons) }\end{array}$ & $1,176,386$ & $1,180,386$ & 294,018 & 608,656 & $24,986,322$ \\
\hline
\end{tabular}

Source: State of West Virginia, Annual Report of the Department of Mines (Charleston: 1945), 42-43.

The labor shortage symptomatic of the coal industry during World War II did not impede West Virginia mines. Despite the immense manpower needs of the United States military, coal operators in West Virginia had few difficulties in finding enough workers to meet the fuel demands of war industry in the early years of the war. Total mine employment in West Virginia rose between 1940 and 1943. By 1943, however, mechanization of the West Virginia coal industry was in full swing. The result of the 
increased reliance on machinery to load the coal was a significant and rapid decrease in West Virginia coal mining jobs. By 1945 coal employment in West Virginia had decreased 8.6 percent. $^{43}$

Employment in McDowell County followed a similar pattern. The eradication of hand mining and the rapid utilization of mechanical loaders affected McDowell in a more demoralizing and destructive manner. For example, almost half of the workers at the Carter mines in 1940 were hand loaders, with the rest being classified as either cutting machine workers or general inside labor. By 1945, only about 10 percent of Carter miners were still classified as hand loaders. As a result, Carter employed approximately half the number of miners in 1945 as it had in 1940. These hand loaders also produced about one-quarter of the amount of coal loaded by machine. ${ }^{44}$

Peerless's employment did not decline as much as Carter during the period between 1940 and 1945. The total number of inside workers at Peerless decreased less than 20 percent during the war years. A large layoff did not occur in 1945 at Peerless because of the sheer amount of coal still being loaded by hand at the mine. While the Carter mines, by 1945, were close to completely phasing out hand loading, Peerless still relied on the practice for well over half of its production. More than half of the miners employed by Peerless in 1940 were either hand miners or hand loaders. In 1945 the

\footnotetext{
${ }^{43}$ Ibid., 12.

${ }^{44}$ Ibid., 98-101; State of West Virginia, Annual Report of the Department of Mines (Charleston: 1940), $82-85$.
} 
acquisition of conveyors and mechanical loaders allowed some of the job losses to be absorbed by the creation of crews to man the new machines. ${ }^{45}$

After World War II ended, the move towards complete mechanization of the coal industry accelerated. Lower demand for coal as a result of decreased industrial output of war materials led to a decrease in the amount of coal mined in the United States. The important statistic, however, was the percentage of coal loaded by machine. Between 1945 and 1950 the percentage of coal loaded by machine rose from 48 to 58 percent. It is interesting to note that although coal production in West Virginia fell by 19 million tons between 1945 and 1950, the tonnage of coal loaded by machine actually increased by about three million tons. Employment obviously suffered due to the decreased levels of production and increased use of machinery in the late 1940s. There were 10,000 fewer miners employed in West Virginia in 1950 than had worked in 1945. In hindsight, as will be shown below, the decline in employment was not a trend that would destroy an industry, but it was one that affected thousands of people whose jobs were lost. ${ }^{46}$

By 1950, the use of mechanical loading expanded in McDowell County. The Carter Coal Company sold its Coalwood and Caretta mines. The three mines were reorganized as Olga Coal Company, after the two primary mines owned by the company. The Olga company completely eradicated hand loading in its two major

\footnotetext{
${ }^{45}$ State of West Virginia, Annual Report of the Department of Mines (Charleston: 1940), 82-85; State of West Virginia, Annual Report of the Department of Mines (Charleston: 1945), 98-101.

${ }^{46}$ State of West Virginia, Annual Report of the Department of Mines (Charleston: 1945), 12; State of West Virginia, Annual Report of the Department of Mines (Charleston: 1950), 11.
} 
mines, Olga \#1 and Olga \#2. Hand loading on conveyors continued at the company's Caretta \#5 mine, but the output of that mine was miniscule. Peerless also continued the 
Table 3. Employment in Selected McDowell County Coal Mines, 1940 and 1945.

\begin{tabular}{|c|c|c|c|c|c|c|c|c|c|c|}
\hline & $\begin{array}{l}\text { Olga \#1 } \\
\text { (Coalwood) } \\
1940\end{array}$ & $\begin{array}{l}\text { Olga \#1 } \\
\text { (Coalwood) } \\
1945\end{array}$ & $\begin{array}{l}\text { Olga \#2 } \\
\text { (Caretta) } \\
1940\end{array}$ & $\begin{array}{l}\text { Olga \#2 } \\
\text { (Caretta) } \\
1945\end{array}$ & $\begin{array}{l}\text { Caretta } \\
1940\end{array}$ & $\begin{array}{l}\text { Caretta } \\
1945\end{array}$ & $\begin{array}{l}\text { Peerless } \\
\text { (Vivian) } \\
1940\end{array}$ & $\begin{array}{l}\text { Peerless } \\
\text { (Vivian) } \\
1945\end{array}$ & $\begin{array}{l}\text { County } \\
\text { Totals } \\
1940\end{array}$ & $\begin{array}{l}\text { County } \\
\text { Totals } \\
1945\end{array}$ \\
\hline Pick Men & 0 & 0 & 0 & 0 & 0 & 0 & 132 & 0 & 501 & 0 \\
\hline $\begin{array}{l}\text { Mechanical } \\
\text { Men }\end{array}$ & 0 & 28 & 0 & 37 & 0 & 0 & 0 & 20 & 155 & 545 \\
\hline $\begin{array}{l}\text { Conveyor } \\
\text { Workers }\end{array}$ & 0 & 0 & 0 & 0 & 0 & 0 & 0 & 20 & 493 & 507 \\
\hline $\begin{array}{l}\text { Hand } \\
\text { Loaders }\end{array}$ & 407 & 55 & 503 & 0 & 123 & 81 & 131 & 116 & 9,979 & 5,017 \\
\hline $\begin{array}{l}\text { Machine } \\
\text { Men and } \\
\text { Helpers }\end{array}$ & 10 & 9 & 13 & 14 & 10 & 7 & 10 & 16 & 614 & 719 \\
\hline $\begin{array}{l}\text { General } \\
\text { Labor }\end{array}$ & 403 & 434 & 462 & 474 & 141 & 96 & 130 & 163 & 6,120 & 6,788 \\
\hline $\begin{array}{l}\text { Total Inside } \\
\text { Employment }\end{array}$ & 820 & 526 & 978 & 525 & 274 & 184 & 403 & 335 & 17,862 & 13,576 \\
\hline
\end{tabular}

Source: State of West Virginia, Annual Report of the Department of Mines (Charleston: 1940), 82-85; State of West Virginia, Annual Report of the Department of Mines (Charleston: 1945), 98-101. 
mechanization of its mines during this period. Ninety-three percent of Peerless's production was loaded mechanically. The rest was hand loaded onto conveyors. In all of McDowell County, over half of the county's total production was loaded by machine. $^{47}$

Table 4. Production and Machinery in Selected McDowell County Coal Mines, 1950.

\begin{tabular}{|c|c|c|c|c|c|}
\hline & $\begin{array}{l}\text { Olga \#1 } \\
\text { (Coalwood) }\end{array}$ & $\begin{array}{l}\text { Olga \#2 } \\
\text { (Caretta) }\end{array}$ & Caretta \#5 & $\begin{array}{l}\text { Peerless } \\
\text { (Vivian) }\end{array}$ & $\begin{array}{l}\text { County } \\
\text { Totals }\end{array}$ \\
\hline $\begin{array}{l}\text { Cutting } \\
\text { Machines }\end{array}$ & 5 & 14 & 0 & 9 & 451 \\
\hline Conveyors & 0 & 0 & 0 & 3 & 140 \\
\hline $\begin{array}{l}\text { Mechanical } \\
\text { Loaders }\end{array}$ & 14 & 18 & 0 & 7 & 200 \\
\hline $\begin{array}{l}\text { Production } \\
\text { Mechanically } \\
\text { Loaded (in } \\
\text { tons) }\end{array}$ & 932,909 & 960,514 & 0 & 456,376 & $10,770,213$ \\
\hline $\begin{array}{l}\text { Loaded on } \\
\text { Conveyors } \\
\text { (in tons) }\end{array}$ & 0 & 0 & 28,336 & 32,255 & $1,303,468$ \\
\hline $\begin{array}{l}\text { Hand Loaded } \\
\text { (in tons) }\end{array}$ & 0 & 0 & 0 & 0 & $8,706,999$ \\
\hline $\begin{array}{l}\text { Total } \\
\text { Production } \\
\text { (in tons) }\end{array}$ & 932,909 & 960,514 & 28,336 & 491,631 & $20,780,680$ \\
\hline
\end{tabular}

Source: State of West Virginia, Annual Report of the Department of Mines (Charleston: 1950), 50-51.

${ }^{47}$ State of West Virginia, Annual Report of the Department of Mines (Charleston: 1950), 50-51. 
Interestingly, the employment in McDowell County coal mines overall actually increased by more than 15 percent between 1945 and 1950. The same was not true for the Olga and Peerless companies. The Olga mines employed 10 percent fewer miners in 1950 than in 1945, with only forty-two workers still loading coal by hand. These hand loaders, as mentioned above, worked at the Caretta \#5 mine, which had always been technologically behind in comparison to the two Olga mines. The rest of the miners either worked on mechanical loaders, cutting machines, or as general inside labor. Peerless also lost employees by 1950, about 15 percent. The primary reason for the continued decrease in number of workers at Peerless was the cessation of hand loading into cars. By the end of 1950 there were no hand loaders in the Peerless mine. $^{48}$

\footnotetext{
${ }^{48}$ Ibid., 124-127; State of West Virginia, Annual Report of the Department of Mines (Charleston: 1945), 98-101.
} 
Table 5. Employment in Selected McDowell County Coal Mines, 1950.

\begin{tabular}{l|lllll}
\hline & $\begin{array}{l}\text { Olga \#1 } \\
\text { (Coalwood) }\end{array}$ & $\begin{array}{l}\text { Olga \#2 } \\
\text { (Caretta) }\end{array}$ & Caretta \#5 & $\begin{array}{l}\text { Peerless } \\
\text { (Vivian) }\end{array}$ & $\begin{array}{l}\text { County } \\
\text { Totals }\end{array}$ \\
\hline $\begin{array}{l}\text { Mechanical } \\
\text { Workers }\end{array}$ & 39 & 43 & 0 & 30 & 743 \\
$\begin{array}{l}\text { Conveyor } \\
\text { Workers }\end{array}$ & 0 & 0 & 42 & 18 & 857 \\
$\begin{array}{l}\text { Hand } \\
\text { Loaders }\end{array}$ & 0 & 0 & 0 & 0 & 4,535 \\
$\begin{array}{l}\text { Machine } \\
\text { Men and }\end{array}$ & 18 & 45 & 6 & 30 & 923 \\
$\begin{array}{l}\text { Helpers } \\
\text { General }\end{array}$ & 442 & 445 & 38 & 209 & 8,754 \\
Labor & & & & & \\
$\begin{array}{l}\text { Total Inside } \\
\text { Employment }\end{array}$ & 499 & 533 & 86 & 287 & 15,812 \\
\hline
\end{tabular}

Source: State of West Virginia, Annual Report of the Department of Mines

(Charleston: 1950), 124-127.

During the 1950s companies introduced machines that subsequently revolutionized the mining process, the most important of which was the continuous mining machine manufactured by the Joy Company. A twenty-six foot long, eight-foot wide machine consisting of a ripper bar designed to tear coal from the face and place it into a central hopper, the continuous miner combined the cutting and loading of coal into a single operation. The new machine shortened the time needed to produce a ton of coal and did it with much less labor than traditional mining methods. A continuous miner with ten men produced three times as much coal as thirty men loading coal by 
machine. Fortune magazine stated that the total cost per ton to mine coal was $\$ 5.28$ for hand loading, \$3.79 for machine loading, and $\$ 3.16$ for continuous mining. ${ }^{49}$ The increased production resulting from the continuous mining machine also changed the industry. Consequently, the mechanical loader led to a 20 percent increase in productivity between 1930 and 1950 . During the 1950s, productivity rose about 100 percent due to the continuous mining machine. ${ }^{50}$

Production in West Virginia declined from 1950-1955, yet the amount of coal loaded by machine increased drastically. During this period, the tonnage of coal loaded by machine increased 38 percent. As Table 6 shows, however, fewer miners held onto their jobs, as employment decreased between 1950 and 1955, declining by almost 50 percent. $^{51}$

\footnotetext{
49 “Continuous Coal Mining,” Fortune 41 (June 1950): 191.

${ }^{50}$ Ibid., 114; Ronald L. Lewis, Black Coal Miners in America: Race, Class, and Community Conflict, 1780-1980 (Lexington: University Press of Kentucky, 1987), 178-180; Seltzer, Fire in the Hole, 65; Shifflett, Coal Towns, 204.

${ }^{51}$ State of West Virginia, Annual Report of the Department of Mines (Charleston: 1955), 5.
} 
Table 6. West Virginia Coal Production and Employment, by Method of Mining, 1951-1955.

\begin{tabular}{l|lllll}
\hline & 1951 & 1952 & 1953 & 1954 & 1955 \\
\hline $\begin{array}{l}\text { Hand } \\
\text { Loaded (in } \\
\text { tons) }\end{array}$ & $34,042,454$ & $26,443,899$ & $18,207,787$ & $12,224,865$ & $12,668,243$ \\
$\begin{array}{l}\text { Conveyor } \\
\text { Loaded (in } \\
\text { tons) }\end{array}$ & $25,671,846$ & $20,668,689$ & $15,248,902$ & $8,421,291$ & $7,621,829$ \\
$\begin{array}{l}\text { Machine } \\
\text { Loaded (in } \\
\text { tons) }\end{array}$ & $92,356,473$ & $84,609,103$ & $88,833,642$ & $84,229,243$ & $106,053,859$ \\
$\begin{array}{l}\text { Total } \\
\text { Production } \\
\text { (in tons) }\end{array}$ & $152,070,773$ & $131,721,681$ & $122,290,331$ & $104,875,399$ & $126,343,859$ \\
$\begin{array}{l}\text { Total } \\
\text { Employed }\end{array}$ & 84,117 & 75,733 & 62,251 & 48,047 & 47,149 \\
\hline
\end{tabular}

Source: State of West Virginia, Annual Report of the Department of Mines

(Charleston: 1955), 5.

The early 1950s were critical years in McDowell County. Olga Coal Company closed the Caretta \#5 mine, because it ceased to be profitable. Production at the two remaining Olga mines increased marginally between 1950 and 1955. During the same period, however, over half of Olga's inside miners lost their jobs. Any production increase, no matter how small, with an employment decline the magnitude of Olga's, was the result of the continuous mining machine. The continued mechanization movement destroyed Peerless. Peerless did not buy a continuous miner and paid dearly as a result. Production fell marginally from 1950 to 1955; employment fell as well. 
Because Peerless did not further mechanize its mines, it could not produce the tonnage needed at a low enough price to compete with larger mines. Because of the difference between Peerless and its competitors, the company went out of business and closed its Vivian mine in $1960 .^{52}$

Throughout the late 1950s the coal industry in West Virginia continued to see a decline in both production and employment. By 1960 coal mining was almost a completely mechanized process. About 89 percent of the coal produced in 1960 was machine loaded, mostly by the continuous mining machine. McDowell County also followed the path to complete mechanization. Market conditions impaired the two Olga mines; they produced less coal in 1960 than in 1955. The increased use of the continuous mining machine caused the expected decline in employment as well. As noted in Table 7, in McDowell County as a whole, production fell by about six million tons and about 700 jobs were lost between 1955 and $1960 .^{53}$

\footnotetext{
${ }^{52}$ Ibid., 30; State of West Virginia, Annual Report of the Department of Mines (Charleston: 1950), 50-51, 124-127.

${ }^{53}$ State of West Virginia, Annual Report of the Department of Mines (Charleston: 1960), 62-63.
} 
Table 7. Production and Employment at Selected McDowell County Coal Mines, 1955 and 1960.

\begin{tabular}{l|llll}
\hline & $\begin{array}{l}\text { Olga \#1 } \\
\text { (Coalwood) }\end{array}$ & $\begin{array}{l}\text { Olga \#2 } \\
\text { (Caretta) }\end{array}$ & $\begin{array}{l}\text { Peerless } \\
\text { (Vivian) }\end{array}$ & County Totals \\
\hline $\begin{array}{l}\text { Total } \\
\text { Production (in } \\
\text { tons) (1955) }\end{array}$ & $1,103,702$ & 818,958 & 484,948 & $20,912,416$ \\
$\begin{array}{l}\text { Total Inside } \\
\text { Employment } \\
\text { (1955) }\end{array}$ & 319 & 289 & 221 & 7,846 \\
$\begin{array}{l}\text { Total } \\
\text { Production (in } \\
\text { tons) (1960) }\end{array}$ & 869,334 & 630,866 & N/A & $14,802,004$ \\
$\begin{array}{l}\text { Total Inside } \\
\text { Employment } \\
\text { (1960) }\end{array}$ & 283 & & & \\
\hline
\end{tabular}

Source: State of West Virginia, Annual Report of the Department of Mines (Charleston: 1955), 30; State of West Virginia, Annual Report of the Department of Mines (Charleston: 1960), 62-63.

The patterns of development evident in McDowell County continued throughout the immediate postwar period in the rest of the southern West Virginia coalfields. Large companies with the vision to realize the importance of mechanization thrived, albeit with fewer workers. Mines which either did not have the capital or the foresight to buy loaders, continuous miners, or other machines usually could not compete on the marketplace and ended up closing. Of course there could be other reasons for mine closures, including the "working out" of a coal seam; however, it is clear that mechanization was necessary for the future success of a mine. ${ }^{54}$

\footnotetext{
54 "Working out" refers to the mining of most, if not all, of the available coal in a seam.
} 
In his case study of the Kay Moor mine in Fayette County, Michael Workman reinforces many of my findings about McDowell County. Located in the New River Gorge, the Kay Moor mine opened in 1900. The Low Moor Iron Company of Allegheny County, Virginia, began working on the mine in an attempt to improve the coke supplies to the company's iron furnaces. ${ }^{55}$ During the industry-wide push towards mechanization through the widespread use of loading machines, Workman notes that the company experimented with loaders during the mid-1930s. Despite the use of the loaders, however, the machines loaded no more than 2 percent of the mine's production until they were discontinued in 1937. Another attempt at mechanical loading took place in the early 1940s, yet by 1943 this experiment was over. From that point until 1962 , when the mine closed, miners hand loaded all of the mine's output. ${ }^{56}$

Workman finds that the reason the Kay Moor mine did not mechanize was because management resisted introducing mechanical loaders. According to Workman, there were two reasons for the conservatism of the management at Kay Moor. First, the general manager of the mine believed that mechanization would not be a permanent part of the coal industry; he believed hand loading would continue to account for the bulk of the industry's production. Second, it is possible that management realized that the mine would not have a long life. Within thirty years of its opening, the main headings of the Kay Moor mine had been driven to the edge of the company's property. There was still a large amount of coal available for mining, but it was clear that the

\footnotetext{
${ }^{55}$ Michael E. Workman, "The Kay Moor Mine, 1901-1962: A Case Study of Underground Mechanization in the Bituminous Coal Fields of Southern West Virginia," Canal History and Technology Proceedings 19 (2000): 153.

${ }^{56}$ Ibid., 175-176.
} 
mine would eventually close. The actual reason for the lack of mechanization at Kay Moor does not matter for our purposes. What is important is that the Kay Moor mine experienced a similar evolution as did Peerless. Both companies either failed to mechanize in a timely manner or did not mechanize at all. With the tight markets that the coal industry faced throughout the 1950s, these two companies could not decrease the cost of production enough in order to stay competitive. As a result, both companies closed their mines in the early 1960 s. ${ }^{57}$

The decline of markets for coal and the mechanization of the industry had a significant impact on McDowell County. The competition with oil and gas led to a consolidation of the coal industry, and an effort in the surviving mines to decrease costs through mechanization. Both circumstances created a situation where fewer miners were needed to meet the demand for coal. This is particularly important in McDowell because of the lack of diversity in the county's economy. Once the available coal jobs decreased, the job market in the county constricted to a point not seen before.

The contraction of the job market in McDowell County developed in two ways. First, during the 1950s the job loss in the county was not accompanied by a corresponding decline in the number of mining operations. In 1950 the unemployment rate in McDowell County was about 6.0 percent. Throughout the 1950s the continued mechanization of the mines of the county resulted in a significant rise in the unemployment rate. In 1950 1,557 people were without a job. At first glance this statistic does not seem to be indicative of an economic decline in the county; but, when the number of workers in the labor force, only 16,789 , is taken into account, it is clear

${ }^{57}$ Ibid., 176. 
that something occurred in McDowell County to explain such a rise in the unemployment rate (about 10.2 percent). Mechanization and a lack of economic diversity are the primary reasons for such a drastic decline in the employment prospects in the county. The coal industry employed about 75 percent of McDowell workers in 1950. Although the percentage of people employed by the mining industry declined to a little under 50 percent in 1960, the industry still was the largest employer in the county. With the drastic decline in mining employment during the decade, along with the increase in mining operations, the only explanation that makes sense is mechanization. Increased competition and the decline of markets did not lead to a contraction in the county's industry during the 1950s. The 1960s, however, would be an entirely different example. ${ }^{58}$

Employment prospects during the 1960s improved slightly as the unemployment rate fell to about 8.0 percent. Yet, the number of individuals in the county's labor force continued to fall precipitously. In the twenty-year period from 1950 to 1970 , the number of persons in the labor force fell significantly, as did mining employment. The 1960 s can be considered a decade of contraction, as mine after mine

\footnotetext{
${ }^{58}$ State of West Virginia, Annual Report of the Department of Mines (Charleston: 1950), 128-129; State of West Virginia, Annual Report of the Department of Mines (Charleston: 1960), 68-69; U.S. Dept. of Commerce, Bureau of the Census, United States Census of Population, 1950. General Characteristics. West Virginia: General Data on Age, Sex, Race, Marital Status, Education, Employment, Income, Occupation, Industry, Etc. (Washington: U.S. Government Printing Office, 1952), 48-81; U.S. Department of Commerce, Bureau of the Census, Census of population, 1960. Volume 1. Characteristics of the population : number of inhabitants, general population characteristics, general social and economic characteristics, and detailed characteristics. Part 50. West Virginia (Washington: U.S. Government Printing Office, 1962), 50-94.
} 
closed. In addition to Peerless, over one hundred other mining operations shut their doors during the decade. ${ }^{59}$

During the post-World War II era, McDowell County began to undergo the process of deindustrialization. In contrast to the process of deindustrialization in the industrial Midwest, where plants closed as management transferred production to places with lower labor and production costs, deindustrialization in McDowell County, and Central Appalachia as a whole, was characterized by two points, mechanization and competition in the energy markets. Because the primary industry in McDowell County was coal, a natural resource, management did not have the option of moving production to other areas. The only way to decrease the costs of production was to replace large numbers of miners with machines. Otherwise, if a mine ceased to be profitable, the coal company was forced to shut down the operation. Both strategies were used by the companies and the end result was a drastic decline in the number of jobs available in the county's coal industry. Before we explore the effects of deindustrialization on the inhabitants of McDowell, one other question must be answered. Because McDowell County was so heavily unionized, particularly after the 1930s, what role did the UMWA play in the mechanization process? With so many union members affected by the decline in available jobs in the industry, it is important to explain why the union was unable or unwilling to protect their jobs. Without the

\footnotetext{
${ }^{59}$ State of West Virginia, Annual Report of the Department of Mines (Charleston: 1950), 128-129; State of West Virginia, Annual Report of the Department of Mines (Charleston: 1960), 68-69; State of West Virginia, Annual Report of the Department of Mines (Charleston: 1970), 12; U.S. Census 1950, 48-81; U.S. Department of Commerce, Social and Economic Statistics Administration, Bureau of the Census, 1970 census of population. Volume 1, Characteristics of the population. Part 50, West Virginia (Washington: U.S. Government Printing Office, 1972), 50-296.
} 
institutional support of the union, McDowell's miners were only struggling against the tide of "progress." 


\section{Chapter 4 \\ "American Standards?" The Union and Deindustrialization}

In late 1959, John L. Lewis sat down with a reporter from U.S. News and World Report to reflect on his accomplishments as president of the United Mine Workers of America (UMWA). Lewis responded to questions on numerous issues, including union-management relations, mechanization, and the miners' standard of living. As expected, Lewis spoke in glowing terms of his record. When asked about union cooperation with management, Lewis stated, "The United Mine Workers not only cooperates with the operators on that - we invented the policy. We've encouraged the leading companies in the industry to resort to modernization in order to increase the living standards of the miner and improve his working conditions." With the "progress" achieved by Lewis in the 1950s, there was some attrition within the industry. Lewis understood this fact and downplayed the significance of job losses within the coal industry. He stated that "there are pensions for those above sixty years of age. The younger men go by the tens of thousands into other industries to get jobs. Some of the older men stay in the area and manage to get along with the help of relatives....There is public assistance and Social Security assistance in some cases." To Lewis, the job losses within the coal industry were worth the improved standard of living enjoyed by the miners who continued to work in the mines.

The miner who fifty-five years ago lived in poverty now lives like an ordinary citizen. He is a respectable member of the community. He lives in a modern house, with carpets and rugs. He has a bathroom, TV and every electrical gadget to make household work easier for his wife. His child goes to school.

\footnotetext{
${ }^{1}$ U.S. News and World Report, 9 November 1959.

${ }^{2}$ Ibid.
} 
He can often afford to send him to college. No young man in a mining community now has to go into the mines to work without getting a high school education, as formerly happened....It's true there aren't as many miners. But those young men who have been absorbed in other industries are better off than working in a coal mine underground.",3

To a certain extent, what Lewis said was true. The wage increases and benefits from the Welfare and Retirement Fund did allow working miners a better life. Yet, there were many unemployed miners who found it difficult to adjust without a job. A sense of desperation overtook many of the coal towns throughout McDowell County and the entire Appalachian region. The union, the savior of the miners, failed to support its members who found themselves displaced by machines. From the early years of the twentieth century, the union supported the operators in their effort to mechanize. John L. Lewis, the primary figure in UMWA history, continued this policy. As outlined in his work, The Miners' Fight for American Standards, Lewis believed that mechanization was absolutely necessary to stabilize the industry and improve the lives of mine workers. Lewis held this view throughout his forty-year presidency of the union. With the 1950 contract, Lewis was able to use his support of mechanization to gain operator approval for a Welfare and Retirement Fund that provided health and pension benefits for workers. Mechanization was a process within the coal industry that the union probably could not have stopped. The Fund, however, represented the perfect opportunity to soften the effects of unemployment and to provide the workers of McDowell County some hope. The UMWA could have provided assistance in relocation or job retraining, but it failed to ask for royalty payments high enough to

\footnotetext{
${ }^{3}$ Ibid.
} 
provide consistent benefits to working miners, much less unemployed workers. As a result, the UMWA failed all of its members.

Although Lewis's vision of the coal industry was not brought to fruition until the 1950s, the UMWA as an organization supported the principle of technological advancement within the coal industry from the earliest days of the twentieth century. In every era, the union's position on mechanization was influenced by the economic forces of the day. During the first two decades of the twentieth century, the coal industry experienced significant growth. National coal production increased from 212 million tons in 1900 to 569 million tons in 1920. Consequently, employment grew by a similar margin during the same period. Coal is, however, an industry characterized by boom-and-bust cycles, so there were several economic downturns in the industry even during this period of long-term growth. Despite these downturns, it seemed as if the industry would experience consistent long-term growth. During this growth period, the union had an excellent opportunity to fight for policies on mechanization beneficial to the membership of the UMWA. The leadership did not, however, hesitate in announcing their unabashed support for mechanization. Keith Dix, in his important work, What's a Coal Miner to Do?, suggests that the leadership was so focused on gaining recognition that it feared any opposition to technology might be interpreted as union intransigence. In an era where public and operator approval were critical to establish union credibility, the union could not be seen as standing in the way of "progress."

\footnotetext{
${ }^{4}$ Keith Dix, What's a Coal Miner to Do? The Mechanization of Coal Mining (Pittsburgh: University of Pittsburgh Press, 1988), 126-127.
} 
There were mixed signals coming from the miners' camp, however. During the earliest days of mechanization, the union sought to ensure all members could earn about the same annual wage. Mechanization complicated the situation because miners were paid by the ton. A miner working with a cutting machine could produce coal at a higher rate, so consistent tonnage rates resulted in a major discrepancy in wages. To reach the goal of consistency in wages throughout the industry, the union had to ask for higher tonnage rates for pick miners, which was difficult for the mines to achieve. ${ }^{5}$

There were other reasons for opposing machinery. In 1897, the UMW Journal discussed the potential use of machinery within the coal industry. The author's opinion was ahead of its time, and would become increasingly important as companies implemented new technologies during the twentieth century. The biggest problem, according to the author, was the physical impact the new machinery would have on the miner. Miners would have a difficult time keeping pace with the undercutting machine and over-exertion would result. Furthermore, inhaling "several cubic feet per minute of powder smoke, diluted with machine mining dust and deleterious gasses...is going to tell on rising generations." machinery "the natural enemy of the coal miners, it destroys the value of their skill and experience, obliterates their trade and reduces them to the ranks of common laborers."7 Moreover, machinery increased the danger of falling rock, and economic issues,

\footnotetext{
${ }^{5}$ Maier B. Fox, United We Stand: The United Mine Workers of America, 1890-1990 (Washington: UMWA, 1990), 122-123.

${ }^{6}$ Quoted in Fox, United We Stand, 123; See also: Barbara E. Smith, Digging our Own Graves: Coal Miners and the Struggle over Black Lung Disease (Philadelphia: Temple University Press, 1987).

${ }^{7}$ Quoted in Fox, United We Stand, 123.
} 
particularly contracts that limited the number of loaders to each machine and the amount each person could load, created significant bitterness among many miners. ${ }^{8}$

Despite the increased opposition to mechanization from miners of the early twentieth century, some workers clearly believed that technological advancement within the coal industry would improve their standard of living. Loading machines of the day tended to make the work a little easier and had the potential to shorten the workday. Consequently, miners had more time to spend with their families and participate in other leisure activities. The only official position the UMWA held on technology was that workers should receive some of the financial windfall from technological expansion. As profits for the companies increased, the UMWA held, worker wages should move upward as well. The person primarily responsible for the union's early policy on mechanization was UMWA president John Mitchell. ${ }^{9}$

As president of the union during the first decade of the twentieth century, John Mitchell presided over one of the largest expansion periods in UMWA history. Under his leadership, union membership grew ten times, operators in the South signed union contracts for the first time, and the union organized the anthracite miners in 1902. At that point, the UMWA was the largest union in the country, with a membership of 330,000. ${ }^{10}$ Mitchell brought the success that characterized the union during this era into his relationships with the members of the union, and as a consequence enjoyed

\footnotetext{
${ }^{8}$ Fox, United We Stand, 122-123.

${ }^{9}$ Ibid., 123-124.

${ }^{10}$ Joseph M. Gowaskie, "John Mitchell: A Study in Leadership” (Ph.D. Dissertation, Catholic University of America, 1968), 287; Dix, What's a Coal Miner to Do?, 150.
} 
widespread popularity and support for his policies. Nevertheless, he had his critics. Socialists within the union, for example, criticized Mitchell for his conservative policies and business unionism. ${ }^{11}$ Radicals insisted that he was wrong on many of the important issues of the day, particularly industrial unionism, the organization of workers based on industry rather than craft. Conservatism in the leadership was important, according to Mitchell, because using conciliation and arbitration to settle disputes was important in establishing a good relationship with employers. These policies were more realistic and, therefore, more appropriate for solving the problems faced by the miners. For conciliation to work, however, the union and its workers had to cooperate with business and show respect for the labor agreement. Thus, Mitchell opposed all wildcat strikes. Mitchell also joined the National Civic Federation, a top business organization and prohibited political discussion in the United Mine Workers Journal, supporting the American Federation of Labor's official nonpartisan policy. ${ }^{12}$ Mitchell brought his conservatism to union policy on mechanization. In his 1903 work, Organized Labor, Its Problems, Purposes and Ideals and the Present and Future of American Wage Earners, Mitchell fully explained his, and the union's, philosophy on machinery.

\footnotetext{
${ }^{11}$ Business unionism describes when organized labor focuses more on economic interests than political reform. Company property rights are upheld and, in many cases, labor leaders who practiced business unionism had strong relationships with business leaders. The best historical example is the American Federation of Labor's nonpartisan policy. For more information, see: Victoria C. Hattam, Labor Visions and State Power: The Origins of Business Unionism in the United States (Princeton, NJ: Princeton University Press, 1993).

${ }^{12}$ Arthur C. Everling, "Tactics over Strategy in the United Mine Workers of America" (Ph.D. Dissertation, Catholic University of America, 1968), 287; Craig Phelan, Divided Loyalties: The Public and Private Life of Labor Leader John Mitchell (Albany: State University of New York Press, 1994), 146-149; Dix, What's a Coal Miner to Do?, 150-151.
} 
The unionists believe that machinery should be introduced with the least possible friction and the least possible hardships to individuals. When the employer is asked to increase wages or reduce hours, he frequently asks for an interval of a certain time in order to allow him to accommodate himself to the change, and the labor unions are now beginning to recognize the necessity of making great changes in industrial conditions by slow degrees. An equal duty should rest upon the employer to make alterations gradually, so as to extend the effect of the change over a series of years, and thus permit the workmen to accommodate themselves to the new condition. ${ }^{13}$

Mitchell defended the union movement against business criticism that unions usually obstructed technological advancement. He noted that there had been past union opposition to mechanization, but "at the present time all but a small minority of workmen are converted to the view that machinery is a necessity, to which it is foolish and unwise, if not impossible, to offer permanent resistance."

Despite his belief that technological advancement was necessary, Mitchell recognized that there were negative consequences of mechanization. For Mitchell, leading the union during a period of great craft and skill within the coal industry, the most negative aspects of technology were the decline in employment caused by the new machines and the loss of traditional craft positions. The primary impact of machines was that "in hundreds of thousands of cases the machine drove the man from his work and in many instances substituted for patiently and painfully acquired skill the services of an untrained laborer, of a little boy or girl." ${ }^{, 15}$ Despite the potentially negative consequences of mechanization, Mitchell recognized the futility of resistance.

13 John Mitchell, Organized Labor (Philadelphia: American Book and Bible House, 1903), 249-250; Morton S. Baratz, The Union and the Coal Industry, Reprint edition (New York: Kennikat Press, 1973), 53.

${ }^{14}$ Mitchell, Organized Labor, 247, 253.

${ }^{15}$ Ibid., 248. 
Improved technology is a natural phenomenon in a capitalistic economy, and Mitchell understood this fact. Mitchell argued that any obstruction of the introduction of machinery would cause operators "to send the new machines into non-union establishments, and by means of competition of the new with the old, of the better with the worse methods of production gradually to lower and reduce the union scale." ${ }^{, 16}$ In an era characterized by the union's struggle for legitimacy, Mitchell cannot be faulted for his practical stand on mechanization. ${ }^{17}$

Even though he was not against mechanization, Mitchell demanded that new technology be implemented within a union framework designed to protect members' interests. "While there can be no doubt that the sudden introduction of machines often works great hardship to working men, the method of securing redress is not by fighting the machine but by obtaining control over it." ${ }^{, 18}$ For Mitchell, control meant keeping bargaining rights and control over new jobs which may be created as a result of the new technology. Furthermore, in order to protect the livelihoods of the workers who would continue to mine coal after the implementation of new machinery, mechanization must evolve within a union setting. "Where trade unions do not exist, employers with the worst and oldest machinery and the most antiquated methods manage to eke out a precarious existence by underpaying and starving their workmen, but where trade unionism is able to enforce a definite maximum wage, these less skillful and less

\footnotetext{
${ }^{16}$ Ibid., 252.

${ }^{17}$ Dix, What's a Coal Miner to Do?, 151-152.

${ }^{18}$ Mitchell, Organized Labor, 249.
} 
adequately equipped manufacturers must either introduce the modern appliances or go to the wall."19

Although Mitchell spoke of the impact of mechanization within the framework of his business unionism, he failed to consider one very important fact. He dealt with the job losses that could occur as a result of mechanization, but he did not discuss the private and social costs of any unemployment that might result from the introduction of machinery in the coal industry. Mitchell, through his narrow business unionism that was so common during the early twentieth century, only saw the employer-employee relationship as an essentially cooperative one. Therefore, issues such as mechanization, if the union focused only on narrow concerns such as wages and working conditions, could be used to benefit the employee, as well as the employer. Since the social and economic costs of mechanization did not affect current workers, the problem was outside the scope of business unionism. Dealing with the social issues stemming from mechanization would have committed the union to social change, which could, in the union philosophy of the day, deflect attention from the more important matters such as union recognition, wages, and working conditions. ${ }^{20}$

The union presidents who followed Mitchell continued his policy on mechanization. John White, in a speech to the Northwestern Coal Dealers' Association in 1911, noted "'some day the machine may prove a blessing instead of an evil to the miners, but that will be when a more equitable system of distribution [of profit] is

\footnotetext{
${ }^{19}$ Ibid.

${ }^{20}$ Dix, What's a Coal Miner to Do?, 152-153.
} 
adopted.",21 In 1916, White used the increasing productivity of mines that had mechanized as the basis for his call for a shorter workday. At the end of World War I, the union clarified its position in The Case of the Bituminous Coal Mine Workers. In this work, the UMWA noted that the support of mechanization was a safety issue. The more productive a mine became, the less time miners had to work at the face, therefore the risk of injury or death from mine accidents declined significantly. Also, the belief that mechanization would aid the industry by consolidation and increasing profits for operators was further developed. The industry needed "'the establishment of such modern standards that the operator must either equip his mine and operate it efficiently or go out of business.",22

During the presidential administrations of John Mitchell and John White, the UMWA developed a coherent policy on mechanization: Technological improvement in the coal industry was inevitable and the union would not actively oppose mechanization. As long as mechanization occurred within a union framework, it could benefit both the operators and miners. Furthermore, both Mitchell and White developed the view that mechanization would lead to the stabilization of the coal industry by forcing small, marginal operations either to invest in machinery or to go out of business. The ideas promulgated by Mitchell are particularly important because of their influence on John L. Lewis. Lewis, who was president of the UMWA for forty years, oversaw the period of greatest technological and social change within the coal

\footnotetext{
${ }^{21}$ Quoted in Fox, United We Stand, 355.

${ }^{22}$ Quoted in Fox, United We Stand, 357.
} 
industry. Lewis's philosophy would drive the union's position on technology long after his presidency was over.

John L. Lewis, the central figure in the history of the UMWA, was born in 1880 near Lucas, Iowa. The son of a miner, as a child Lewis saw many of the problems faced by miners. As an adult, Lewis began his meteoric rise through the union ranks in the Illinois coalfields. As a local president and lobbyist at the Illinois legislature, Lewis was quickly recognized as a rising star in organized labor. Samuel Gompers, president of the American Federation of Labor (AFL), offered Lewis a position as an organizer for the AFL. Through his work with the AFL, Lewis caught the eye of John White, who brought Lewis back to the UMWA in 1917. When John White resigned to take a position with the Fuel Administration, catapulting Vice-President Frank Hayes to the union presidency, Lewis, at Hayes' request, was appointed vice-president of the UMWA. During 1918 and 1919, Hayes fell ill and, on January 1, 1920, he resigned. John L. Lewis thus became the president of the UMWA, a post he held until $1960 .^{23}$ During the World War I period, a movement grew within the UMWA advocating that the industry's problems could be alleviated by the nationalization of the mines. This belief was rooted in the socialist influence within the union prior to the war. Frank Hayes, whose brief presidency bridged the presidencies of White and Lewis, was an Illinois socialist who supported the nationalization movement. In 1919, Hayes called a National Policy Committee Meeting where, among other things, he proposed a nationalization plan that the committee accepted. There were several

\footnotetext{
${ }^{23}$ Fox, United We Stand, 222-223.
} 
reasons for Hayes' support for nationalization. First, Hayes saw his proposal as a move of solidarity in support of British coal miners who, at the time, were advocating nationalization of British coal mines. Second, he believed the Fuel Administration, which had stabilized the industry during the war, proved that government could serve a positive role in the economy. Third, Hayes, and others on the policy committee, thought that government ownership of the mines would lead to the elimination of geographic wage differentials, the reduction of the work-day and week to spread the available work around, and wage increases to protect the miners against inflation. ${ }^{24}$

There were several weaknesses in Hayes' vision of nationalization. First, he did not have an implementation plan for nationalization. Second, Hayes did not deal with many important details, including mechanization. But Hayes did not remain in office long enough to work out many of these details. By early 1920, Hayes had resigned and Lewis, who was particularly hostile to the idea of nationalization, became UMWA president. Although he publicly supported nationalization at times, privately Lewis would not support the movement and worked to destroy it by neglecting to carry out resolutions and taking advantage of the post-World War I red scare to publicly discredit union liberals and socialists. Despite Lewis's opposition to nationalization, the movement refused to die during the early 1920s. Led by John Brophy, president of UMWA District 5, progressives offered a plan for nationalization in their 1922 pamphlet How to Run Coal: Suggestions for a Plan of Public Ownership, Public Control, and Democratic Management in the Coal Industry. The Nationalization

\footnotetext{
${ }^{24}$ John Brophy, A Miner's Life (Madison: University of Wisconsin Press, 1964), 151-152; Dix, What's a Coal Miner to Do?,156; Everling, "Tactics," 134-136.
} 
Research Committee, which was headed by Brophy and appointed by Lewis, dealt with the legal questions of government ownership, including the cost and policymaking issues. With the depression faced by the coal industry during the 1920 s, it seemed that nationalization was needed to provide stabilization to the industry. ${ }^{25}$

Although Lewis felt the need to support publicly the nationalization movement in the early 1920s because of the internal politics of the UMWA, his conservative business-unionism would not allow him to privately advocate such a move. By the mid-1920s, Lewis had solidified his control over the union and was more able to distance himself from the nationalization movement. Lewis primarily used the $U M W A$ Journal and its editor, Ellis Searles, as his mouthpieces on the issue. In May 1923, a New York newspaper reporter interviewed Searles. In this interview, Searles outlined Lewis's policy for promoting stability in the coal industry: "Shut down 4,000 coal mines, force 200,000 miners into other industries, and the coal problem will settle itself. The public will then be assured of an adequate supply of low-priced fuel."26 To Lewis, nationalization was not a responsible plan to stabilize the coal industry. Lewis did more than just use the Journal to further his own ideas; he used it to defuse the nationalization movement that was so popular among the rank-and-file. For example, Lewis refused to publicize the Nationalization Research Committee's plan in the Journal and would not allow debate on the issue. Furthermore, after the discussion of

\footnotetext{
${ }^{25}$ United Mine Workers of America, Nationalization Research Committee, How to Run Coal (Washington: United Mine Workers of America, 1922), 10-12; Melvyn Dubofsky and Warren Van Tine, John L. Lewis: A Biography (New York: Quadrangle, 1977), 73; John M. Laslett, Labor and the Left: A Study of Socialist and Radical Influence in the American Labor Movement, 1881-1924 (New York: Basic Books, 1970), 222-226; Dix, What's a Coal Miner to Do?, 156-160; Everling, "Tactics," 139-186.

${ }^{26}$ Quoted in Brophy, A Miner's Life, 171.
} 
nationalization by one committee member during a New York speech, Searles criticized him in the Journal for discussing a plan that had not been approved by the union and had been "prepared largely by a bunch of Greenwich Village Reds." ${ }^{, 27}$ After this attack on the committee's work, the members resigned and nationalization research was ended by the UMWA. The 1924 UMWA convention adopted another resolution calling for the nationalization of the coal mines; however, the resolution had no teeth without the support of the Lewis administration. John Brophy wrote, "the resolution was adopted, but the national organization made no effort whatever to translate its pious generalities into activity. It was not intended, by the administration, to be a plan for further education and research, but rather as an epitaph over the grave of the nationalization idea. I kept hoping that we could reform our lives and resume the campaign, but that hope was never realized. ${ }^{28}$

Lewis's intransigence on nationalization can be seen by analyzing his 1925 book, The Miners' Fight for American Standards. In this work, Lewis not only discussed the union's fight for collective bargaining, decent working conditions, and good pay for all miners, but he also presented his plan to stabilize the coal industry, which was in the midst of an economic downturn caused by overproduction and excess capacity. In slight contrast to earlier union presidents, Lewis insisted that mechanization was the key to future stabilization of the coal industry. The book outlined Lewis's basic, conservative political and economic philosophies. He brushed

\footnotetext{
${ }^{27}$ Ibid.

${ }^{28}$ Ibid., 175.
} 
off the nationalization movement, rejected government control of the nation's coal mines, and supported "the operation of natural economic laws to bring about a permanent improvement." 29 He went on to say that "the policy of the United Mine Workers of America at this time is neither new nor revolutionary. It does not command the admiration of visionaries and Utopians. It ought to have the support of every thinking business man in the United States, because it proposes to allow natural economic laws free play in the production and distribution of coal. ${ }^{, 30}$

Lewis also hoped to use his work to change the perception of the UMWA and himself. Lewis wrote as if he spoke for the entire union; in effect, Lewis sought to create the perception that he had centralized power within the UMWA. This, of course, was not necessarily true. John Brophy, for example, gave Lewis a relatively tough race for the union presidency in 1926. Brophy sought to make nationalization the primary issue in that election. Lewis won the election; however, there is evidence that some fraud took place in Lewis's favor. After 1926, Lewis was never again seriously challenged for the presidency of the UMWA, thus completing the consolidation of his power. Another reason for his writing the book was to change the public perception of the UMWA. The union had been attacked during the investigation of the President's Coal Commission in 1923 and had little public support because of the refusal of the union to make wage concessions under the Jacksonville Agreement. Lewis justified the union's policy of not making wage concessions by arguing that higher wages served

\footnotetext{
${ }^{29}$ Lewis, Miners' Fight, 46-47.

${ }^{30}$ Ibid.
} 
two purposes. First, high wages led to greater purchasing power for miners, he argued, and "mass production can only be maintained by a purchasing power in the home market sufficient to make it possible."31 Second, he believed that high wages would lead to increased mechanization in the mines and would drive out marginal producers who perpetuated "obsolete methods.",32

The crux of the Lewis plan for industrial stabilization rested on the belief that if the UMWA succeeded in holding the line on wages, then the high labor costs would force mine operators to install machinery in an effort to remain competitive. In this way, union operators would lower their cost of production and drive out of business mines which were less efficient and, most likely, non-union. The decline in the number of mines would also help the industry as a whole by confronting the problem of overexpansion and excess capacity. By cutting into the overall production of the industry, mechanization would potentially bring the industry's capacity more in line with costumer demand. Lewis also believed that stabilization of the industry could only be achieved by organizing all coal miners. Lewis declared that, "every car of Non-union coal at present represents an intrusion into the general industrial system of a malignant influence; because this coal could not be produced and sold, as it is now, without the denial of American rights in the mines from whence it comes and without an uneconomic system of railroad favoritism to boost it to market.",33

\footnotetext{
${ }^{31}$ Ibid., 46-47.

32 Ibid., 108.

${ }^{33}$ Ibid., 180.
} 
Another important component of Lewis's plan for the stabilization of the coal industry revolved around wage levels. Lewis insisted that the tonnage system of payment, in which companies paid miners by the amount of coal they mined, should be replaced by a time-payment system, whether by the hour or by the day. A uniform daily wage would serve the same role as mechanization would. A uniform wage would, in Lewis's mind, raising the labor costs per unit for inefficient mines with low productivity, would eventually force these mines, which were a drag on the industry, out of business. Lewis also contended that a uniform wage would lead to labor harmony within the coal industry, as many strikes started as a result of local disputes caused by the piecework system, and that these local strikes would decline significantly by the shift to a daily wage. Another important component to Lewis's plan was the elimination of regional wage differences. The vast differences in pay rates between the different coal-mining regions tended to keep too many inefficient mines, particularly non-union mines, open. Lewis consistently supported his wage policy and, eventually, his policy became the union's policy with the centralization of the power of the UMWA president. Morton Baratz claimed in 1955, “The union's current [wage] strategy is easy to describe. By raising wage rates (and labor costs per ton) and by eliminating regional wage-rate differentials, heavy pressure to mechanize will be brought to bear on all firms, especially the relatively high-cost operations....The increased use of machines will enable the union to exact even higher wage rates or shorter hours or both. Higher wage rates encourage mechanization which, in turn, permits still higher wage rates." ${ }^{34}$

\footnotetext{
${ }^{34}$ Baratz, The Union and the Coal Industry, 72.
} 
During the late 1920s, however, economic and labor conditions forced Lewis to back off of his high-wage position in order to consolidate his control over the union. Facing pressure from nonunion coal mines, the rank-and-file in Illinois and Ohio pressured Lewis to allow district unions to negotiate local wage rates. Lewis thought that backing off of his high-wage policy would be a mistake, because a high wage rate would force larger coal operators to implement machinery to cut down on labor costs and force smaller firms out of business. Historian Keith Dix argues that this policy may have worked had the union succeeded in its effort to organize the entire industry in order to impose a uniform national wage. Furthermore, had Lewis been able to combat local control the union would have succeeded in negotiating a wage scale for machine operators and in eliminating limitations on the use of machinery. Because of the economic depression in the coal industry during the 1920s, Lewis failed on both counts. In order to protect his hard-fought control of the UMWA, Lewis gave in to the pressures of the rank-and-file. ${ }^{35}$

For numerous reasons, Lewis failed in his effort to effect true consolidation within the coal industry. Formed during the depressed years of the 1920s and 1930s, Lewis's program of consolidation and mechanization could not be thrust to the top of the union's agenda. With the New Deal's protection of workers' rights to bargain collectively under the National Industrial Recovery Act and the Wagner Act, the UMWA was in a stronger political position. With the start of World War II, the material needs of the country forced the nation's mines to mechanize in order to keep up with demand. After the war, the union was in a more stable position and could use

${ }^{35}$ Dix, What's a Coal Miner to Do?, 164. 
its mechanization policy to work with the operators and, at the same time, improve the lives of the union's members.

Although World War II brought an improvement in the fortunes of the coal industry, some analysts, including Lewis, recognized that the industry was in a longterm decline that reached back to the 1920s. Lewis knew as early as 1945 that, because of the expectation for another post-war depression, the coal industry could not afford to employ as many workers as it had during the war. As a result of this realization, along with his natural support for mechanization policy, Lewis accepted, if not welcomed, the loss of jobs and union members that naturally result from mechanization. Lewis was not willing, however, to allow companies to mechanize without just compensation for the members of the union. Lewis contended that the miners should not only be paid well, but future contracts should establish a new benefit plan for union miners. This benefit package, later known as the Fund, would, as Curtis Seltzer puts it, "shape coal politics for the next thirty years."36

The call for a health plan was particularly important because prior to 1945 , union miners had only sporadic health coverage and no pensions. Still in use in many mining towns was the company doctor system. Mine operators developed the company doctor system during the earliest days of the coal industry to provide health care for their workers. Paying a monthly fee to the company, miners and their families called upon the doctors whenever the need arose. The inherent problem with this paternalistic

\footnotetext{
${ }^{36}$ Richard P. Mulcahy, A Social Contract for the Coal Fields: The Rise and Fall of the United Mine Workers of America Welfare and Retirement Fund (Knoxville: The University of Tennessee Press, 2000), 3; Curtis Seltzer, Fire in the Hole: Miners and Managers in the American Coal Industry (Lexington: University Press of Kentucky, 1985), 56.
} 
institution was the doctor being a company employee who could be used as an instrument of exploitation, namely as a labor spy. Although there were many fine company doctors, in many towns the doctors provided substandard care at best. There was also little freedom for the miners. It was almost impossible for miners to go to doctors other than the company's because this would require the miner to travel to an independent town within the area. The very nature of the company town system, therefore, prompted miners to demand control over their health care. ${ }^{37}$

The unusual prosperity of the immediate post-war period allowed Lewis and the UMWA the opportunity to fight for a benefit plan in 1945. Lewis recognized that the strong performance of the industry would not last; therefore, time was of the essence. If the UMWA was to win a benefit package for its miners, the principle would have to be established during a period of prosperity. Otherwise, before long the coal companies would be able to cite economic conditions as an excuse not to provide benefits to union miners. ${ }^{38}$

Despite the ideal economic conditions that existed within the coal industry in 1945, Lewis was initially unable to secure acceptance of the benefit plan. The fight over the benefit package took place in several rounds of collective bargaining after 1945. Two issues surfaced after Lewis proposed an industrial health plan in the spring

\footnotetext{
${ }^{37}$ Alan Derickson, "Part of the Yellow Dog: US Coal Miner Opposition to the Company Doctor System, 1936-1946," International Journal of Health Sciences 19, no. 4 (1989): 714-718; Alan Derickson, "From Company Doctors to Union Hospitals: The First Democratic Helath-Care Experiments of the United Mine Workers of America," Labor History 33 (Summer 1992): 329; Mulcahy, A Social Contract for the Coal Fields, 3; Seltzer, Fire in the Hole, 56; See Joel T. Boone, A Medical Survey of the Bituminous Coal Industry (Washington: U.S. Department of the Interior, 1947).

${ }^{38}$ Dubovsky and Van Tine, John L. Lewis, 456; Mulcahy, A Social Contract for the Coal Fields, 2-3; Seltzer, Fire in the Hole, 57.
} 
of 1945, the cost and quality of the benefits for the miners, and who would control the operations of the plan. Lewis proposed that the union control the health plan and that the plan be financed by a nickel-per-ton royalty on all union-mined coal. Although the coal industry was enjoying a period of prosperity in 1945, the mine operators still rejected all union demands that would increase costs. When Labor Secretary Francis Perkins supported the mine operators, Lewis realized that the situation was not conducive for a successful conclusion so he signed a contract that did not include a health plan. ${ }^{39}$

A year later during contract negotiations, Lewis once again brought up the issue of a health plan. The 1946 proposal included hospital and medical services, life and medical insurance, and rehabilitation for injured miners, among other benefits. Interestingly enough, pensions were not a part of Lewis's early proposals. The 1946 plan would be financed by the operators through a 7 percent payroll tax, with the union managing all of the finances and programs of the plan. ${ }^{40}$ Seltzer notes that the difference between financing the plan through a tonnage royalty or a payroll tax was extremely important.

A tonnage tax tied benefits to the level of unionized production. That link gave Lewis an incentive to promote mechanization, which promised to boost production. A payroll tax, on the other hand, tied benefits to the number of working miners and their wage scale. Depending on how it was calculated, a payroll tax could act as a drag on mechanization. In 1945, Lewis argued that the Fund should be financed by a tonnage royalty; in 1946, he switched to a payroll tax. He would reverse himself one final time. ${ }^{41}$

\footnotetext{
${ }^{39}$ United Mine Workers Journal (hereafter cited as UMWJ)15 May 1946; Dubovsky and Van Tine, John L. Lewis, 376; Mulcahy, A Social Contract for the Coal Fields, 3; Seltzer, Fire in the Hole, 57.

${ }^{40}$ UMWJ, 15 May 1946; Mulcahy, A Social Contract for the Coal Fields, 7.

${ }^{41}$ Seltzer, Fire in the Hole, 57.
} 
Once again, the operators refused to negotiate with Lewis in 1946 and, unlike 1945, the union called for a strike. About 340,000 coal miners walked off the job in an attempt to win acceptance of the proposed welfare plan. The scale of this strike was so immense that the federal government began to pressure both sides to settle the dispute, and the coal operators agreed in principle to a health and retirement plan. Negotiators for the industry argued that the Fund should be operated jointly, but Lewis resisted this proposal insisting that companies could then veto the programs of the Fund. Once again, animosity between the union and operators over the health plan led to deadlock as the companies repudiated their earlier agreement with the union. The industry declared that the payroll tax was the sticking point in the negotiations and, once again, the deadlock forced the federal government to get involved in the dispute. ${ }^{42}$

President Harry S. Truman knew that it was critical to keep the mines open because coal fueled the American economy. Therefore, on May 22, 1946, the president ordered Julius A. Krug, the Secretary of the Interior, to seize American mines affected by the strike. In this instance, however, seizure did not mean ownership of the mines by the federal government. Instead, the federal government would administer the mines and hold all profits in escrow until the government returned the mines to the owners. There were both economic and political reasons for this action. Secretary Krug was not particularly worried about preserving all the privileges coal operators had enjoyed during the war, but rather the affect a coal shortage on the post-war economy.

\footnotetext{
${ }^{42}$ UMWJ, 15 April 1946; Mulcahy, A Social Contract for the Coal Fields, 7-8; Seltzer, Fire in the Hole, 57-58.
} 
Furthermore, 1946 was a mid-term election year and Krug found it beneficial to negotiate a settlement with Lewis as quickly as possible. ${ }^{43}$

The contract signed between the federal government and the UMWA was an important victory for John L. Lewis. The union won a wage increase of 18.5 cents per hour, but that was not the most important feature of the 1946 contract. Secretary Krug also agreed to two separate welfare funds, one each for pensions and health care, which would be financed by a nickel-per-ton royalty for each. The pension plan would be administered by a committee of three trustees. The industry and union would each appoint one member of the committee and the two groups together would appoint the third trustee. Particularly important to Lewis was the agreement on the health care program. The contract stated that the health plan would be run by three trustees; all three trustees would be union appointees, bringing to fruition the original union proposal on the Fund. ${ }^{44}$

The importance of the federal seizure of the nation's coal mines in 1946 is that the contract signed between Secretary Krug and John L. Lewis set the precedent for a later agreement with the operators containing the Fund provisions. In 1947, the companies and the UMWA signed a contract containing most of the terms from the federally-negotiated contract of the previous year. The agreement merged the two separate pension and health care plans into one single Welfare and Retirement Fund. The Fund would be financed by a ten-cent per ton tax and jointly administered by a

\footnotetext{
${ }^{43}$ Dubovsky and Van Tine, John L. Lewis, 458; Mulcahy, A Social Contract for the Coal Fields, 8; Seltzer, Fire in the Hole, 58.

${ }^{44}$ Seltzer, Fire in the Hole, 58.
} 
three-member board, much like the earlier pension plan. This was a fateful agreement, however. The Fund's income depended on the productivity of the industry, not on the number of workers. As a result, the union had an even larger incentive to support the mechanization of the mines. Actually, downsizing would aid those miners who could survive the attrition. With fewer employees, workers would enjoy better medical care and larger pensions. There were problems other than simple job loss, however. Because coal production financed the Fund, there formed a real interest in minimizing anything that could hinder production. As a result, Fund trustees saw occupational health and safety as constraints on production, and little was done on either during the 1950s and 1960s. One final result of the Fund's reliance on tonnage royalties was the partnership that developed between Lewis and the coal industry during the 1950s. Cooperation between labor and capital is not necessarily a negative development; however, the partnership between the UMWA and the coal operators did not support the rank-and-file very well. ${ }^{45}$

Although a very close relationship eventually developed between John L. Lewis and the coal operators, Lewis had to fight a continuous battle between 1947 and 1950 to force the operators to meet their obligations to the Fund. The two parties deadlocked over a proposed pension. The operators' trustee sued multiple times in an attempt to put an end to the Fund. There developed a pattern of strikes and injunctions. In 1948, the contract continued the Fund, but the coal industry found itself at the beginning of another downturn. Poor business forced the industry to battle Lewis once again over the royalty. In 1949, operators decided to stop paying the tax and, as a result, the Fund

${ }^{45}$ Ibid., 59; Mulcahy, A Social Contract for the Coal Fields, 10. 
went bankrupt. Labor relations between the union and industry were at a low ebb in 1949. Combined with falling demand for coal, the problems within the industry eventually forced both sides to rethink their relationship, which they did in the Spring of $1950 .^{46}$

In addition to the inherent economic problems associated with coal, the primary problem facing the bituminous coal industry during the late 1940s was the lack of leadership. There were too many bituminous coal companies, and those companies could not agree on a common course of action in regard to labor relations. ${ }^{47}$ Lewis himself recognized the problems created by the lack of leadership in unionmanagement negotiations. An article in Fortune noted:

When asked... what the major difficulty was in collective bargaining, Lewis replied: 'In one sentence...the lack of leadership among those with whom we deal....If you were to ask me today who could speak for the industry on any suggested idea that would be constructive in itself for the industry, I would say very frankly that there are no such men. ${ }^{48}$

Lewis was not the only industry insider to notice the need for strong, unified leadership among the coal operators. The largest operators in the bituminous coal industry realized that the industry needed a new framework for collective bargaining. By 1949 a small group of operators, most likely led by Consolidation Coal and U.S. Steel, got together "to do some long range thinking," recollected Harry M. Moses of

\footnotetext{
${ }^{46}$ Mulcahy, A Social Contract for the Coal Fields, 12-13; Seltzer, Fire in the Hole, 59.

${ }^{47}$ It is important to differentiate between the bituminous and anthracite coal industries in the discussion on strong industry leadership because the anthracite industry had already found their leader, Richard Grant.

48 "Lewis' Apparent Heir," Fortune 40 (May 1949): 190.
} 
U.S. Steel in $1955 .^{49}$ This group sought to achieve industry stability without the need for federal intervention. To meet this goal, the operators would pursue summit diplomacy with Lewis. They also approved the appointment of George Love of Pittsburgh-Consolidation Coal to negotiate and restructure the relationship between capital and labor in the bituminous coal industry. ${ }^{50}$

Love became powerful within the bituminous coal industry because of his position as president of Pitt-Consol, which was the most powerful coal company in the country. Love was able to forge an alliance between two of the three main groups of coal companies, the northern operators and the captive mines. ${ }^{51}$ From this alliance sprung a new group, the Bituminous Coal Operators' Association (BCOA) in 1950. It became clear soon after its formation that the BCOA intended to control the costs of labor throughout the industry. ${ }^{52}$

Love had three goals in the initial negotiations with the UMWA. He wanted a "new stable and binding contract...that neither party have the right to cancel or suspend...during the intervening two and one half year period." ${ }^{, 53}$ Love's second goal

${ }^{49}$ UMWJ, 1 May 1955.

${ }^{50}$ Seltzer, Fire in the Hole, 62-63.

${ }^{51}$ The other primary group of coal companies was the southern commercial operators. Captive mines were mines owned by steel companies. The coal from captive mines would not be sold on the market; instead the coal would be used to produce steel. In McDowell County, U.S. Steel owned a number of captive mines, primarily in the Gary area. For more info on the U.S. Steel operations in the Gary area see Alex P. Schust, Gary Hollow: A History of the Largest Coal Mining Operation in the World (Harwood, MD: Two Mule Publishing, 2005).

${ }^{52}$ Thomas N. Bethell, Conspiracy in Coal (Huntington, WV: Appalachian Movement Press, 1971), 1314; See also Edie Black and Fred Goff, The Hanna Industrial Complex (New York: North American Congress on Latin America, 1969); Dubovsky and Van Tine, John L. Lewis, 496; Mulcahy, A Social Contract for the Coal Fields, 31; Seltzer, Fire in the Hole, 63-64.

${ }^{53}$ National Coal Association Industry Bulletin, no. 2749 (27 January 1950): 2. 
was to eliminate the right for the union to strike at will, which would be the most difficult goal to meet. The third goal was to continue the royalty payment to the welfare fund but that payments should only go to miners who worked for the companies that contributed to the Fund. Furthermore, if the union would guarantee labor peace and work to keep labor costs in check, the BCOA would allow Lewis to control the welfare fund. ${ }^{54}$

Although it would have been difficult to get Lewis to give up the right of the union to strike under normal circumstances, the federal courts gave Love the upper hand in the negotiation process. After Lewis had organized a walkout on February 11, 1950 in response to a ten-day federal court injunction barring strikes under the TaftHartley Act, the courts served the UMWA with a contempt citation for continuing the stoppage. After the government asked for a permanent injunction, Judge R.B. Kleech issued a ruling that stopped the union from asking for certain non-wage provisions to be written into the contract, including the demand for "a closed or union shop, limitation of the benefits of the welfare fund to union members, the 'able and willing' clause, or the right to stop work during "memorial periods." ${ }^{\prime 55}$ It seemed that this ruling forced Lewis to give up the right to strike. However, the union never appealed the judge's ruling. Lewis recognized that the industry was changing and that strikes would serve no purpose in a period of long-term decline in demand. Instead, Lewis announced a thirteen-point list of demands, which included:

\footnotetext{
${ }^{54}$ Seltzer, Fire in the Hole, 64.

${ }^{55}$ Coal Age 44 (March 1950): 141.
} 
a guaranteed annual wage based on 200 working days; 7 1/2 hour work day, portal- to-portal; an increase in the basic wage from $\$ 14.05$ to $\$ 15.50$ a day...; an increase in the welfare-fund payment from 20 cents to 35 cents a ton; a new board of trustees for the fund, with the guarantee that the operators would cooperate with the union and its welfare program; abandonment by the operators of all lawsuits against the union, now totaling millions of dollars. ${ }^{56}$

It was clear, however, that these demands were negotiable. As noted in the $U M W A$ Journal after the negotiations were concluded, "the UMWA had proposed to negotiate a contract without any previous commitments in nay way, shape or form on either the economic or controversial legal issues, such as the union shop.. ${ }^{, 57}$

Despite the union's being in a disadvantageous situation as a result of Judge Kleech's ruling, Love needed Lewis to remain active in industry affairs, if any solution to the industry's long-term problems were to be found. It was no longer in the interest of the bituminous coal industry to break the UMWA, as it had been in previous years. Breaking the union would lead to instability in the form of local strikes and increased price competition resulting from the lack of consistent union wage scales. The end result would then be a drastic decline in profits. To Love, the better approach was to form a strong business relationship with Lewis and the UMWA in an effort to ensure the long-term health of the bituminous coal industry. Love noted the problems that the industry and union needed to solve in a speech to the Edison Electric Institute on June 7, 1950. According to Love, the issues were "(1) labor relations; (2) competition within the industry; (3) competition from other fuels; and (4) maintaining earning ability to

\footnotetext{
${ }^{56}$ Ibid.

${ }^{57}$ UMWJ, 15 March 1950.
} 
permit continued progress." ${ }^{, 58}$ The capital-labor alliance would, ideally, alleviate all four of the primary problems. Love and Lewis would be able to stabilize labor relations through their positions of power. Through this stabilization of the industry, the UMWA and the BCOA could enact uniform labor costs throughout the entire bituminous coal industry. Uniform labor costs would result in consolidation as small, inefficient operators who could not afford the higher union wage rates would be forced out of business. Because of consolidation, only large companies that could invest in machines would remain in business, thus increasing the productivity of the entire industry. Finally, an alliance between Lewis and the operators would solve the final two problems outlined by Love. Labor stability would allow large coal companies to negotiate long-term supply contracts from big consumers only if the coal industry could promise a predictable supply of coal at a low price. This would improve coal's standing in relation to other fuels and the earning ability of the coal companies which remained in business. ${ }^{59}$

Fortune noted how important the 1950 contract was to the development of new mining technology: "In the coal industry 1950 may be remembered as the year of the great shakeout — and also as Year One of its technological revolution." ${ }^{, 60}$ The issue was not, however, mentioned in the language of the contract. Instead, there was an implied understanding between Love and Lewis that the union would not fight the mechanization of the coal mines. Of course, from the earliest days of the twentieth

\footnotetext{
${ }^{58}$ Coal Age 44 (June 1950): 191.

${ }^{59}$ Mulcahy, A Social Contract for the Coal Fields, 31; Seltzer, Fire in the Hole, 65.

60 “Continuous Coal Mining," Fortune 41 (June 1950): 114.
} 
century the UMWA consistently noted how important mechanization was to the stabilization of the coal industry. Love knew that this was the policy of the union, he observed in 1950, “Lewis's union... has one great advantage over many others. It has never fought mechanization." 61 In fact Lewis would take all the credit for the modernization of the industry. As he noted in 1952:

The American coal operators never could have mechanized their mines and increased per-man-day productivity unless they were compelled to do so by the pressure of the organization of the mineworkers....We want participation. We ask for it. We ask for it...to compel him to modernize. Otherwise, he wouldn't move. $^{62}$

With the most powerful leader in the history of the union supporting a policy that would eventually lead to the loss of tens of thousands of coal mining jobs, how would the rank and file act? At the 1952 UMWA convention, Lewis summed up the policy for the delegates: "We stand for the usage of all modern equipment and scientific devices and forms that will take the raw materials which God gave our people and make them of increasing value in the marts of trade. We only ask and we will always ask our rightful participation in that new productive efficiency." ${ }^{, 63}$ It seems that most of the rank-and-file accepted mechanization in the mines. The only concession that they pressed the leadership for was a strong seniority clause that would provide protection for those miners with the longest terms of service. The delegates at the conventions did discuss different ideas that would alleviate the negative impact of job loss, including unemployment compensation, shorter workdays to spread out the

\footnotetext{
${ }^{61}$ Ibid.

${ }^{62}$ Coal Age 46 (October 1952): 162.

${ }^{63}$ Coal Age 46 (November 1952): 135.
} 
available work among more miners, better pensions, and health and safety issues associated with the new machinery. Despite the delegates' belief in the importance of these issues, the leadership failed to press for any of them. ${ }^{64}$

For Love and Lewis, the implications of mechanization on competition within the bituminous coal industry were clear. Fortune summed it up best: "Mechanization is now a means of squeezing out marginal mines and thus increasing the industry's profitability. ${ }^{, 65}$ Lewis had always seen, from the earliest days of his presidency, mechanization as a tool to revolutionize the very structure of the coal industry.

Before the technique of the coal industry can be brought to a state commensurate with what the nation has a right to expect, there must be a change in the financial structure of the coal business.... It is obvious that only solvent corporations, sufficiently financed, can undertake the improvements that the times demand. ${ }^{66}$

The idea behind this philosophy was simple, large companies with stable markets would be able to afford mechanization, thus driving out the small, less efficient operators who could not implement machinery. By decreasing labor costs and concentrating production in a select number of larger companies through the agreement between the UMWA and the BCOA, coal would be able to hold off the competition from the alternative fuels by remaining inexpensive and free from labor strife. ${ }^{67}$

Lewis, however, was not willing to ensure labor peace only for increased mechanization. In return for stability, Lewis demanded higher wages and control of the

\footnotetext{
${ }^{64}$ Seltzer, Fire in the Hole, 65-66.

65 “John L. at Bat,” Fortune 43 (March 1952): 52.

${ }^{66}$ John L. Lewis, The Miners' Fight for American Standards (Indianapolis: Bell Publishing, 1925), 110111.

${ }^{67}$ Mulcahy, A Social Contract for the Coal Fields, 31; Seltzer, Fire in the Hole, 66-67.
} 
Welfare and Retirement Fund. The BCOA agreed, as Seltzer notes, in return for the deletion of the right-to-strike clause in the contract. ${ }^{68}$ As Coal Age summed up the contract, "by inference the union gained control of the welfare fund and therefore complete responsibility for its operations."69 The problem for Lewis was financial. Although the UMWA gained control of the Fund's operations and finances, the union never had enough money to fulfill all of its obligations. The contract of 1950 financed the Fund with a 30 cent royalty on every ton of coal mined by BCOA members. The contract further noted the Fund's obligations:

(1)benefits to employees..., their families and dependents for medical or hospital care, pensions on retirement or death of employees, compensation for injuries or illness resulting from occupational activity or insurance to provide any of the foregoing, or life insurance, disability and sickness insurance or accident insurance; (2) benefits with respect to wage loss not otherwise compensated for at all or adequately by tax supported agencies created by federal or state law; (3) benefits on account of sickness, temporary disability, permanent disability, death or retirement; (4) benefits for any and all other purposes which may be specified, provided for or permitted in...the "LaborManagement Relations Act, 1947"...; and (5) benefits for all other related welfare purposes as may be determined by the Trustees within the scope of the Act. $^{70}$

The Fund represented a new era for labor-management relations in the bituminous coal industry. For the first time, miners had control over their own health care, as well as pension benefits. The Fund could go much further, as well. Lewis wanted a welfare system that would take care of miners and their families by providing unemployment, disability, and other social welfare benefits. The trustees had the right to choose which benefits would be paid by the Fund monies. There were endless

\footnotetext{
${ }^{68}$ Mulcahy, A Social Contract for the Coal Fields, 31; Seltzer, Fire in the Hole, 68.

${ }^{69}$ Coal Age 44 (April 1950): 135.

${ }^{70}$ Quoted in Seltzer, Fire in the Hole, 68.
} 
choices. The Fund could have provided benefits for occupational illness that resulted from the new machinery, notably black lung. It may have been used in a preventative effort, such as implementing techniques and technologies to reduce the immense amounts of coal dust that are released when the continuous miners tear the coal from the seam. It could have been used to lessen the sting of unemployment for those displaced by the new machinery. The Fund could have provided retraining for those workers forced out of the coal industry. The Fund could have also been used to diversify the economies of the coalfield regions which depended so heavily on the industry for their economic livelihood. None of these opportunities came to pass. The only real accomplishment was that the Fund continued to pay medical benefits for unemployed miners for a time. But even this was not enough. That is the real tragedy of this era in UMWA-BCOA labor relations. From the hope represented in the 1950 contract came mostly loss and despair for many miners and their communities. ${ }^{71}$

Why was the Fund unable to fulfill its original mission? The answer is quite simple. The royalty payments outlined in the 1950 contract, as well as later agreements, were never high enough to pay for the services necessary to bring the coal industry into the modern era in a humanitarian way. In fact, the UMWA leadership never asked the BCOA for a royalty that would have allowed for the full scope of benefits. The royalty that was mandated by the contracts barely paid for the health and pension benefits, so any supplemental benefits were out of the question. The fact that

\footnotetext{
${ }^{71}$ Dubovsky and Van Tine, John L. Lewis, 510-513; Mulcahy, A Social Contract for the Coal Fields, 4042; Seltzer, Fire in the Hole, 68-69.
} 
the union did not ask for higher royalties brings up another question. Why did the UMWA fail to negotiate higher royalties? ${ }^{72}$

Seltzer believes there were two reasons that the UMWA leadership failed to negotiate higher royalties for more than twenty years. First, the 1950s and 1960s was a period of serious economic decline in the bituminous coal industry. Markets dried up and sales became stagnant as a result of this downturn. To remain competitive and survive the economic climate of this period, BCOA members had to maintain a very tight control over their costs. With the increasing competitiveness of alternative fuels, even a minimal increase in the cost of coal to the consumer could mean the loss of a sale for the coal companies. Consequently, it is safe to say that the BCOA operators would have resisted any increase in the royalties. There is another factor to consider in the analysis of company resistance to higher royalties. Despite the stagnant economic climate of the 1950s and 1960s, the bituminous coal industry's profits rose throughout these two decades. Therefore, the industry perhaps could have afforded an increase in the royalties without passing on the cost to the customer. In the post-industrial period throughout the country, however, industrial management generally resisted any policy that cut into the profits of the company. That is the nature of capitalism; companies driven by profit will seek to maximize those profits with little attention paid to the humanitarian consequences of the company's action. As a result, the BCOA operators would have resisted any increase in the royalties even if the companies could have afforded it because it would have resulted in a decline in the companies' profits. $^{73}$

\footnotetext{
${ }^{72}$ Seltzer, Fire in the Hole, 69.
} 
Second, the union leadership did not ask for a royalty increase because of a larger phenomenon taking place in American industry at the time, the rise of business unionism. Starting with Lewis in the late 1940s and early 1950s, union presidents agreed with the new system of labor-capital relations, in which the union would become an important partner for business. In this "partnership," however, the UMWA, and unions in other industries, would play an essentially subservient role. Unions were content to accept higher wages and increased benefits in exchange for labor peace and a guarantee of the status quo. For the UMWA, the leadership realized the precarious situation facing the bituminous coal industry during the early 1950s. As a result, the leadership believed that their own survival depended on keeping costs down and maintaining labor peace. To do this required a partnership with the coal industry. ${ }^{74}$

The BCOA was more than happy to use Lewis for its own purposes. In his statement about the signing of the 1950 contract, Love noted:

This $2 \frac{1}{2}$ year contract gives the industry its first real opportunity for stability in the last decade....The operators definitely established the right to control their own production and their mining facilities. The union asked for a cooperative administration of the Welfare Fund and we are giving it to them....The responsibility [for the Fund] is squarely on the shoulders of the union and if it fails, the public and ourselves will look directly at the union.

The coal business is not a sick industry as it has been said recently. This country is one of the very few where coal mining is still in private hands operating under a free enterprise system. I hope that from this contract will come such mutual understanding and we will do away with coal strikes in the future. ${ }^{75}$

\footnotetext{
${ }^{73}$ Ibid.

${ }^{74}$ Ibid.

${ }^{75}$ Quoted in Seltzer, Fire in the Hole, 69-70.
} 
Although Lewis had been a thorn in the side of the coal operators for many years, his reaction was eerily similar to Love's:

It is [a] reasonable assumption that for a substantial period of time the industry can abate its labor warfare and apply itself, both management and labor, to the constructive problems of producing coal in quantity for the benefit of the American economy at the lowest possible price permitted by modern technique. The Mine Workers stand for the investors of the industry to have a return on their capital; they stand for the public to have coal at the lowest possible price consistent with the right of mine workers to live a free life on the same standards and with the same opportunities and under the same laws as other citizens under our flag. ${ }^{76}$

Another reason for the fact that the leadership did not demand a higher royalty in order to meet all of the Fund's obligations was because the rank-and-file did not pressure the leadership to do so for almost twenty years. In the early years of the agreement, the workers who lost benefits were also those who lost their jobs. Since these workers were no longer members of the union, there was no agitation among those who were in a position to push for higher royalties. Furthermore, miners who remained employed during the 1950s often felt so lucky to have a job with benefits that they did not want to "rock their own boat."," However, the Fund began to drift away from those who it was designed to serve. One major reason for this situation was the rise of business unionism within the bituminous coal industry. As the leadership became more closely associated with the operators, their bond with the rank-and-file weakened. Since the union leadership controlled the Fund's finances, the Fund began to fail its constituents. Also, the consolidation of union power in the president, which Lewis accomplished more than two decades before, precluded any coordinated attack

\footnotetext{
${ }^{76}$ Quoted in Bethell, Conspiracy, 8.

${ }^{77}$ Seltzer, Fire in the Hole, 69.
} 
on the Fund by the miners. If a member of the rank-and-file questioned the administration of the Fund or its policies, that member was quieted. Through the economic climate, the relationship with the operators, and the power enjoyed by the union's leadership, the rank-and-file had little voice to protest the problems with the administration of the Fund. ${ }^{78}$

What were the problems with the administration of the Fund? Despite the problems inherent from the fact that the union never asked for a high enough tonnage to fulfill its mission, other problems soon developed as well. From the highest year of national production in 1947, production consistently declined throughout the 1950s. The declining tonnage rates put a hindrance on even the health care system and the pensions. As a result, the declining royalty payments forced the Fund's board of trustees to make some very difficult decisions. The directors decided to cut benefits and limit the number of miners who were eligible for health benefits and pensions. As a result, miners who had been loyal to Lewis and the UMWA for many years often lost part or all of their benefits. For example, in 1962 the directors decreed that a union miner had to retire from a union mine in order to be eligible for a union pension. This was a significant problem because the loss of jobs in union mines and increasing numbers of non-union mines forced loyal union men to make a difficult decision. The miners could either migrate, enter a non-union mine, or let their family starve. Many men decided to enter non-union mines, thus losing their union pension. ${ }^{79}$

\footnotetext{
${ }^{78}$ Ibid.; Dubovsky and Van Tine, John L. Lewis, 510-513.

${ }^{79}$ Robert H. Zieger, John L. Lewis: Labor Leader (Boston: Twayne Publishers, 1988), 173.
} 
Another significant problem in the administering of the Fund dealt with the health care provided for union members. In the early 1950s, the directors of the Fund decided to open a series of union-run hospitals to provide medical care for its members. This was an innovative idea that would not only provide health care for the miners, but also had the potential to improve the medical care miners and their families received. For a very short amount of time, the hospital system worked as planned. However, the hospitals soon ran into financial trouble. Mismanagement, combined with the decline in royalty payments stemming from the decline in production, resulted in the hospitals being operated at a continuous loss. Eventually, the financial situation with the hospitals became so poor that the union sold the hospitals in 1964 at a loss of $\$ 14$ million. Even after the union sold the hospitals the health care portion of the Fund continued to fail the union's members. The directors cut many of the benefits provided to the miners. Doctors employed by the UMWA, in an effort to minimize strains placed on the Fund, failed to recognize the existence of health conditions caused by the new machinery, particularly black lung, for many years. Exacerbating the debilitating effects of miners suffering from the disease with no hope of compensation, the failure of union doctors to recognize black lung and other occupational diseases, further underscores the fact that the union leadership had distanced itself from the rank-andfile. $^{80}$

\footnotetext{
${ }^{80}$ Ibid.; Harry M. Caudill, My Land is Dying (New York: Dutton, 1971), 104-107; Derickson, Black Lung: Anatomy of a Public Health Disaster (Ithaca, NY: Cornell University Press, 1998), 87-111; Mulcahy, A Social Contract for the Coal Fields, 75-82; 98.
} 
John L. Lewis retired as union president in January 1960, ending one of the most significant periods in the history of the UMWA. He was eventually succeeded by Tony Boyle, a former Lewis associate who had very little empathy for the miners. Although Lewis did consolidate his power within the UMWA and ruled the union as a virtual dictator for many years, he had a true concern for the welfare of the miners. Throughout the 1960s, numerous advocates asked Lewis to denounce Boyle for mismanagement of Fund monies, corruption, and violence that characterized his administration. Lewis refused to do so. Privately, however, Lewis did say that hiring Boyle as his assistant in 1948 was "the worst mistake I ever made." ${ }^{\prime 1}$ Consumer advocate Ralph Nader asked Lewis shortly before his death in June 1969 to call for a grassroots revolt against the Boyle-run union. Once again, Lewis failed to do this. When Lewis died, he left a legacy of great success in the battle for unionization in the 1920s and 1930s, and in the formation of the Congress of Industrial Organizations (CIO). There was also a legacy of great failure: the lack of democracy within the UMWA, Lewis's turn towards collaboration, and the failure of the Fund to truly serve the members of the UMWA. ${ }^{82}$

From the earliest days of the twentieth century, the leadership of the UMWA consistently advocated the modernization of the coal industry through the mechanization of the production process. This was at the center of John L. Lewis's plan for stabilization of the industry. Lewis argued that the best way to ensure the continued success of the bituminous coal industry would be through unionization.

\footnotetext{
${ }^{81}$ Quoted in Dubofsky and Van Tine, John L. Lewis, 526.

${ }^{82}$ Dubofsky and Van Tine, John L. Lewis, 526-527.
} 
Unionization would increase the labor costs to mine coal, which would foster mechanization. Only large, stable companies could afford the implementation of machinery, thus leading to consolidation of the industry as small companies either sold out or went out of business. Mechanization was a slow process, but the union's support for the practice, coupled with the use of the strike, led to the 1950 agreement. With the increased competition from other fuels and the loss of market share, members of the BCOA believed that labor peace was crucial to the survival of the coal industry. As a result, Lewis was able to get more benefits for his miners, under the auspices of the Welfare and Retirement Fund.

Mechanization was an inevitable process in the coal industry. The real tragedy of this story is not necessarily the job losses that resulted from the increased use of technology, but the lack of support given to those who lost their jobs. The Fund represented an opportunity to soften the sting of unemployment through providing unemployment benefits, retraining, help with migration costs, or reinvestment in coalfield communities long dependent on the coal industry. The directors of the Fund provided none of these benefits. Furthermore, miners who remained employed in the coal industry often suffered the loss of their benefits as the Fund suffered from mismanagement and bankruptcy. Without the support of their union, miners had to look within themselves for deliverance from the hopelessness of their situation. With job prospects poor, folks from southern West Virginia made the conscious decision to provide for their families by leaving the area and looking for work elsewhere. Thousands of former miners and young families just making their way in the world left West Virginia behind in an attempt to better their, and their children's, lives. 


\section{Chapter 5 \\ You Can't Go Home Again: Out-Migration from McDowell County}

As described earlier, during World War II, McDowell County enjoyed a period of prosperity and a quality of life not seen for a long time. The depression in coal throughout the 1920s and 1930s made life in the coalfields precarious at best. However, with the boom years of the 1940s, more people were working in the coal mines of McDowell County than ever before. The culture of the coalfields is a unique phenomenon that has been explored in numerous academic studies. The isolation of southern West Virginia during the industrial period forced coal operators to build coal camps to house the workers brought into the region to mine the coal. Furthermore, the native, white population of the region could not supply a work force adequate for the needs of the growing coal industry. For example, the population of McDowell County in 1880 was only 3,078 . As a result, the industry began a process of importing labor, either European immigrants or African Americans from the South. ${ }^{1}$

Despite the disparate peoples brought into the southern West Virginia coalfields to work in the mines, the different ethnicities and nationalities formed a bond unlike any other. Throughout many oral histories and other first-hand accounts, interviewees consistently mention how important community was to them. Donald Bowles, who migrated from McDowell County in 1965, noted when talking about his childhood during the 1940s. "Most of the people in school were on a pretty equal basis. We were

\footnotetext{
${ }^{1}$ Joe William Trotter, Coal, Class, and Color: Blacks in Southern West Virginia, 1915-1932 (Urbana: University of Illinois Press, 1990), 19-25. See also: David Alan Corbin, Life, Work, and Rebellion in the Coal Fields: The Southern West Virginia Miners, 1880-1922 (Urbana: University of Illinois Press, 1990); Crandall A. Shifflett, Coal Towns: Life, Work, and Culture in Company Towns of Southern Appalachia, 1880-1960 (Knoxville: University of Tennessee Press, 1991); Ronald L. Lewis, Black Coal Miners in America: Race, Class, and Community Conflict, 1780-1980 (Lexington: University Press of Kentucky, 1987).
} 
always kind of like a family."2 The economic problems within the coal industry created havoc on this camaraderie enjoyed by many in McDowell County. As mines either mechanized or closed, the loss of employment left many coal miners at an impasse. Miners had to make decisions about their future. The lack of economic opportunity did not necessarily force miners out of the county, but it did require careful thought. If the inhabitants of McDowell determined to make their lives in the county, then it was probable that the quality of life for them and their families would decrease significantly as jobs became harder and harder to come by. If they believed that the success and survival of their family could be assured only by migrating to areas where jobs were available, then they were likely to leave. Everyone, miners and non-miners alike, had to decide whether to stay in the county and try to find another job or to move. Throughout the 1950s, many people in McDowell County chose to make a better life for their families elsewhere. Their migration resulted in a demographic catastrophe for McDowell County as the population fell from 98,887 to 50,666 between 1950 and $1970 .^{3}$ With so many people leaving, an inevitable loss of community developed during the post-war period.

The McDowell migration of the 1950s and 1960s was part of a larger, generalized Appalachian migration during the same period. Several factors influenced the migrants' decision to leave their home. The lack of jobs and opportunity, which

\footnotetext{
${ }^{2}$ Donald Bowles, interview by the author, 5 September 2005, Welch, West Virginia, tape recording, in author's personal collection.

${ }^{3}$ United States Department of Commerce, Bureau of the Census, 1950 Census of the Population, Volume 1, Number of Inhabitants (Washington: Government Printing Office, 1952), 48-8; United States Department of Commerce, Bureau of the Census, 1970 Census of the Population, Volume 1, Characteristics of the Population (Washington: Government Printing Office, 1972), 50-16.
} 
caused an increase in poverty, required the residents of Appalachia to look for areas with greater opportunity. Luckily for the displaced Appalachians, industry in the Midwest flourished during the post-war era. As a result, most of the Appalachians who left their home region relocated to the Midwest. By looking at the flow of outmigration, one can trace the relationship between economic change in Appalachia and job opportunities in the North. As with the specific McDowell migration, Appalachian migration reached its peak during the 1950 s, resulting in significant change throughout the region. For example, sociologist James Brown, who had studied the community of Beech Creek, Kentucky, during the 1940s, was surprised to find that more than half of the population had left the community by the early 1960 s, mostly to Ohio. ${ }^{4}$

To understand the full scope of the migration from Appalachia, it is important to detail the numbers of people who left the region. Between 1940 and 1970, 3.2 million Appalachians migrated, primarily to the Midwest. Half of this migration occurred in the 1950s. The areas hardest hit demographically were Eastern Kentucky, West Virginia, and Southwestern Virginia, those areas of central Appalachia dependent on the coal industry. During the 1950s, Appalachian Kentucky lost one-third of its population, while West Virginia and Appalachian Virginia lost one-fifth. The pattern continued into the 1960s when both Appalachian Kentucky and West Virginia lost 15

\footnotetext{
${ }^{4}$ Chad Berry, Southern Migrants, Northern Exiles (Urbana: University of Illinois Press, 2000), 103; Jon C. Teaford, Cities of the Heartland: The Rise and Fall of the Industrial Midwest (Bloomington: Indiana University Press, 1993), 230; Jacqueline Jones, The Dispossessed: America's Underclass from the Civil War to the Present (New York: Basic Books, 1992), 207-208; Also see: James S. Brown, "The Social Organization of an Isolated Kentucky Mountain Neighborhood" (Ph.d. dissertation, Harvard University, 1950).
} 
percent of their population. In 1981, an estimated six million people who were either born in Appalachia or whose parents were born there lived outside of the region. ${ }^{5}$

World War II was the catalyst for much of the post-war Appalachian migration. During the war, the demand for coal increased precipitously in order to support the war effort. To meet the increased demand, coal companies worked the miners six days a week. The need for coal meant good money for miners. Garnet Fuller, a miner from Maybeury, explained the phenomenon. "When coal was in demand a whole lot, like they get in a big order, they worked six days a week.... Six days was time and a half.", Paul Haynes echoed Fuller's assessment of the effect of World War II on McDowell County. Because so many miners had to leave to mines to enter the service, coal companies scrambled to find enough workers to meet demand. "If you was a good electrician or a good machine man, company tried to get you deferred if they could, and if they did, the miner, I guess, was better off than some farmers or something like that because they could get a deferment, and the company would apply for the man."7 Despite the difficulties facing coal companies during the war, operators succeeded in keeping production at a high enough rate to meet the demands of war industry. Haynes noted the difference in the mines after the beginning of the war.

Production stayed up. During the war with the use of machinery, it began to increase. When I first went to work, the company [mined] by handloading. You get five tons of coal per day per man for each and every employee they

\footnotetext{
${ }^{5}$ Berry, Southern Migrants, Northern Exiles, 110; Jones, The Dispossessed, 227.

${ }^{6}$ Garnet Fuller, interviewed by H. Renee Viers, 26 June 1992, Oral History Collection, Eastern Regional Coal Archives, Craft Library, Bluefield, West Virginia.

${ }^{7}$ Paul Haynes, interviewed by H. Renee Viers, 18 June 1992, Oral History Collection, Eastern Regional Coal Archives, Craft Library, Bluefield, West Virginia.
} 
had. They was making money. When I quite work, if they wasn't getting a hundred tons of coal per day per man, [they] stayed at work they wasn't doing any good. That's slippings in production. When they were handloading, they were satisfied with five tons of coal per day per man. That included the bosses and all, everybody, not just coal miners. The biggest part of coal loaders, good coal loaders, would load from 16 to 20 tons a day. By now with the machines and everything now, if they don't get a hundred tons, laying down on the job. ${ }^{8}$

The war did not only mean opportunities for the men of McDowell County. Women also had the chance to contribute to the war effort and improve their standard of living. Angeline Harmon, who grew up in the Berwind area of McDowell County, contributed to the war effort by moving to Deerborn, Michigan to work in a Chrysler Sub Plant making airplane wings. Harmon's experience, while not part of the Great Appalachian Migration of the post-war years, foreshadowed the predominant pattern for Appalachian migrants. Although she liked her job, Harmon noted that she did not like the city. Furthermore, she had difficulty adjusting in the period immediately following her move to Michigan. In response to a question about her impression of Deerborn, Harmon responded:

I was lost. My sister and I both cried. We set down on a sidewalk in Deerborn, Michigan, and cried like two idiots, but we were scared to death. We never been out of War. She said, "What are we going to do?" I said, "We're going to catch a cab and find this address and settle down. That's what we're going to do." We did, and we found the place and found our girlfriend. We were fine. We got along good then. It was different, I'll tell you that.'

After the war was over, however, the demand for coal declined as a lower amount of coal was necessary to support the nation's industry. Coupled with a high

\footnotetext{
${ }^{8}$ Ibid.

${ }^{9}$ Angeline Harmon, interviewed by H. Renee Viers. 2 July 1992, Oral History Collection, Eastern Regional Coal Archives, Craft Library, Bluefield, West Virginia.
} 
degree of coal company consolidation, mine mechanization, and increased dependence on alternative fuels, thousands found themselves without work. Because the undiversified economy of Central Appalachia depended on coal, many people had few options for providing for their families. Therefore, the displaced miners migrated to areas where they could have a chance at a good life, and the level of out-migration serves as a key indicator of the tremendous social change that characterized the Appalachian region during the post-war period. ${ }^{10}$

In addition to the obvious reasons to leave the region, why did the displaced Appalachians choose the Midwest? There are two primary reasons. First, jobs were being created in metropolitan areas. Since there are few metropolitan areas in Appalachia, with the exception of Knoxville and Chattanooga, Tennessee, these migrants had to go elsewhere. Second, there was a shortage of labor in the Midwestern states, specifically Ohio, Michigan, Illinois, and Indiana. This phenomenon began in the 1920s with the decline of foreign immigration caused by World War I. Even during this first decade of labor shortage in the Midwest, the industries of the region turned to Appalachia for its labor supply. Of course, this early migration declined during the Great Depression, but it picked up again during and after World War II. Because of the booming economy and the labor shortage in the region, Appalachian migrants became the major labor pool for Midwestern cities. ${ }^{11}$

\footnotetext{
${ }^{10}$ Carl E. Feather, Mountain People in a Flat Land: A Popular History of Appalachian Migration to Northeast Ohio, 1940-1965 (Athens: Ohio University Press, 1998), xv; Jones, The Dispossessed, 224, 227-228.

${ }^{11}$ Steven Douglas Wilson, "The Adjustment Process of Southern Appalachian Whites in Cincinnati, 1940-1979" (Ph.D. dissertation, University of Kentucky, 1983), 11; Feather, Mountain People in a Flat Land, xvi-xvii.
} 
The migration from Appalachia did not exist in a vacuum. There are three ways to place this phenomenon into a larger context. First, the Appalachian migration was part of a larger, more generalized migration from the South. Economic difficulties throughout the southern region necessitated widespread migration by both whites from the upland South and blacks from the Deep South. Second, another important shift taking place during this period was the movement of people from rural areas to urban areas. Because of the "foreignness" of their destination, rural Appalachian migrants found it somewhat difficult to adjust to their new surroundings, although this accented idea is somewhat disputed by Chad Berry and James N. Gregory. Third, the most important characteristic of the Appalachian migration is the fact that the people of the region, contrary to common stereotypes of Appalachians as being isolated, fatalistic, and backwards, were willing to migrate in order to provide a better life for their families, through increased income, better housing, and educational opportunities. ${ }^{12}$

Throughout the entire migratory process, kinship networks remained particularly important in the experiences of the Appalachian migrants. The process largely began with the development of a "beachhead," usually by a young man who moved to the destination city in order to find work. Often, the migrant would attempt to move to a regional city to find a job. This attempt to maintain some sort of connection to the region usually failed, however. When all options in his local region became exhausted, the beachhead would move to a place he heard there were jobs,

\footnotetext{
12 James N. Gregory, The Southern Diaspora: How the Great Migrations of Black and White Southerners Transformed America (Chapel Hill: Univeristy of North Carolina Press, 2005), 82-83; Eric H. Monkkonen, America Becomes Urban: The Development of United States Cities and Towns (Berkeley: University of California Press, 1988), 5-6; Berry, Southern Migrants, Northern Exiles, 104; Feather, Mountain People in a Flat Land, xiii.
} 
usually to a Midwestern city. Once there, the migrant found work and, through word of mouth, serve as a contact for friends and family. The beachhead thus became a valuable asset for other migrants. The beachhead gave migrants tips on employment, housing, and adjustment to urban life. Furthermore, the beachhead was also indicative of the demographics of the migration. As with most migrations, young people made up most of the migrants from Appalachia. Many times, the beachhead was married and would, after a time, relocate his family to the destination city. Furthermore, the migration largely consisted of people from the better-off families of the region. As with most migrations, the poorest people, the ones most in need of change, found it extremely difficult to come up with the resources necessary to move to a more promising location. ${ }^{13}$

It has been established that the Midwest was generally the preferred destination for Appalachian migrants, but was there a pattern to the migration? Did people from certain areas go to a particular city? Clyde McCoy and James Brown studied the destination of Appalachian migrants and found that migratory streams of Appalachians had a distinct pattern. Throughout the period of Midwestern migration, these patterns showed remarkable resilience and persistence. Each city in the Midwest received most of its migrants from specific Appalachian regions. For example, West Virginia migrants largely went to Columbus and Cleveland, Ohio, while migrants from Eastern Kentucky primarily went to the Cincinnati region. This raises one very important

\footnotetext{
${ }^{13}$ Clyde B. McCoy and James S. Brown, "Appalachian Migration to Midwestern Cities," in William W. Philliber and Clyde B. McCoy, eds., The Invisible Minority: Urban Appalachians (Lexington: University Press of Kentucky, 1981), 35-78; Feather, Mountain People in a Flat Land, xvii-xviii; Also see: Harry K. Schwarzeweller, James S. Brown, and J.J. Mangalam, Mountain Families in Transition: A Case Study of Appalachian Migration (University Park: Pennsylvania State University Press, 1971).
} 
question, however. Outside of the kinship networks, what largely determined the final destination for Appalachian migrants? The determining factor was primarily the highways. Migrants largely followed the interstate highways to their destination, thus, West Virginians followed Interstate 77 north into Eastern Ohio and migrants from Eastern Kentucky followed Interstate 75 north into Southwestern Ohio and Eastern Indiana, although there were exceptions to this pattern. For example, in their recent work on African American migrants from Benham and Lynch, Kentucky, Thomas Wagner and Phillip Obermiller establish that the migrants from these two small towns moved not only to Cincinnati and Michigan, but also to Cleveland and Chicago. ${ }^{14}$

Another important aspect of the migration to the Midwest was the racial makeup of the migrants. The majority of migrants who left their home in search of better opportunity elsewhere were white. For example, 66.4 percent of residents in 1970 who were former migrants were white. The migrants, of course, eventually became prevalent in working-class suburbs, where they profoundly affected the politics, culture, and society of their destination. The migrants often brought rural traditions to their new homes, which allowed them to keep a semblance of their culture alive. Of course, with traditional views of Appalachian culture, one would expect migrants to be ill-equipped to deal with life in northern cities, but actually migrants often prospered in the North, a trend that will be explored later. An important question derives from this discussion, however. Since migrants from the South (broadly defined

\footnotetext{
${ }^{14}$ Thomas E. Wagner and Phillip J. Obermiller, African American Miners and Migrants: The Eastern Kentucky Social Club (Urbana: University of Illinois Press, 2004), 100-108; Feather, Mountain People in a Flat Land, xiii.
} 
to include Appalachia) were usually white, what happened to the African American population? How does this fit into the experience of McDowell? As with whites, deindustrialization forced African Americans to make the same choice, to migrate or to stay in McDowell. During the period from 1950 to 1970, when the county went through its largest decline in population, the African American population declined precipitously as well. From a high of 24,128 in 1950, the county's African American population dropped to 9,083 by 1970 , a decline of 62 percent. $^{15}$

Migrants found it difficult to leave their familiar lives, and their new lives in the Midwest were not easy. Throughout the adjustment period, Appalachian migrants struggled to cope and often dreamed of life back home, particularly on a farm. Not surprisingly, therefore, many migrants saw their situation as only temporary, and longed to return home as soon as the economic conditions improved. There are many examples of migrants who consistently moved between the Midwest and home. Chad Berry, in Southern Migrants, Northern Exiles, tells of one such tale. Berry recounts a story about a West Virginian who consistently sought to return home for a decade after his first move. Finally, the migrant gave in and permanently moved to Chicago after it became clear that conditions back home would not improve enough for him to provide for his family. ${ }^{16}$

\footnotetext{
${ }^{15}$ Ibid.; Teaford, Cities of the Heartland, 230-231; Alice Carter, "Segregation and Integration in the Appalachian Coalfields: McDowell County responds to the Brown Decision," West Virginia History 54 (1995): 98. For a discussion of migration from another region within Central Appalachia, see Wagner and Obermiller, African American Miners and Migrants.

${ }^{16}$ Lake View Newcomer Committee, Summary of Visits to Southern White Families (Chicago: Lake View Newcomer Committee, 1961), 4; Lewis M. Killian, White Southerners (New York: Random House, 1970), 106; Laurel Shackelford and Bill Weinberg, Our Appalachia: An Oral History (New York: Hill and Wang, 1977), 310; Robert Coles, The South Goes North (Boston: Little, Brown, 1971),
} 
Although many former migrants sought to return, a phenomenon that will be discussed in more detail later, most migrants had to adjust to a permanent life in their new urban homes. After moving from their previous homes, rural Appalachian migrants faced many difficult challenges. The decision to migrate involved many different steps. A migrant faced the severance of community ties, an identity change, and relocation. Migrants modified their value systems to gain acceptance in their new homes. With profound differences in the culture of Appalachia and that of the receiving cities, migrants faced a very difficult adjustment period. Clearly, most of the demands made on migrants to conform to city life required them to change their own values. $^{17}$

During the 1960s, the northern economy entered a downward trend and the opportunity for Appalachian migrants to move to the Midwest declined. Although opportunity lagged in the Midwest, more people sought new lives and followed the traditional migratory streams to Cleveland, Cincinnati, Detroit, and other destinations. A predominant reason for the continued migrations during the 1960s was the new popular culture vision of the "good life," particularly through an increase in consumerism. By the end of the 1960s, however, the luster of migration had begun to wear off, and significant return migration materialized at the end of that tumultuous decade. Migrants returned for three primary reasons. First, the pattern of deindustrialization that affected McDowell County and other coal-producing regions of

618; Berry, Southern Migrants, Northern Exiles, 105; Feather, Mountain People in a Flat Land, xviiixix; Jones, The Dispossessed, 208, 229.

${ }^{17}$ Charleston Sunday Gazette Mail, October 9, 1966; John Photiadis, Selected Social and Sociopsychological Characteristics of West Virginians in their Own State and in Cleveland, Ohio (Morgantown: West Virginia University Appalachian Center, 1970), 36. 
Appalachia began to cause a decline in heavy industry in the Midwest, closing off the source of employment for Appalachian migrants. Second, the period between the late sixties and late seventies saw a revitalization in the coal industry, primarily after the energy crisis of the early to mid-seventies. Third, many former migrants became disillusioned with life in the Midwest and sought a simpler life back home, a process that will discussed in more detail below.

The process of migration could be psychologically difficult for the Appalachian migrant. The migrant had to leave everything that was familiar, the land, friends, and family. Migrants had to enter a world that was new, in both good and bad ways. As recounted by Carl Feather, one West Virginia woman said: “"I am worried about my children moving to the city because I hear every day of children being destroyed, being...run over by cars,... being on dope. One dose of it calls for another, and they go from bad to worse. A lot of them wind up in prison, and a lot of them wind up dead." 18 Not only was the experience of moving to an urban environment frightening, Appalachian migrants faced a different culture that would be difficult to assimilate into. It could be said that the Appalachian experience was comparable to the experience of foreign immigrants during the late nineteenth and early twentieth centuries. One excellent comparison is in the language of the migrants. Like foreign immigrants, Appalachian migrants often faced discrimination, embarrassment, and harassment based on their accents. ${ }^{19}$ One excellent example is the Lockhart family of the Panther

\footnotetext{
${ }^{18}$ Guy Carawan and Candie Carawan, Voices from the Mountains (New York: Alfred A. Knopf, 1975), 69; Feather, Mountain People in a Flat Land, xviii.

${ }^{19}$ Feather, Mountain People in a Flat Land, xviii-xix.
} 
area in western McDowell County. Belinda Lockhart, a child of migrants who moved to Chicago in 1960, discussed the difficulties when moving to a new area:

Moving was quite drastic and we hated it. We wanted to go home and looked forward to moving back. My parents kept the home in WV and our vacations were spent there.

We were called Hillbillies-despite the fact that we wore shoes. We had difficult times communicating. Our English was southern with different expressions and pronunciations. Progress was made when we started high school-they called us Appalachian whites. ${ }^{20}$

Besides cultural difficulties, how did Appalachian migrants adjust economically

to their new homes? The sociologist John Photiadis conducted a study, published in 1970, of West Virginians who, like fellow migrants from McDowell, migrated to Cleveland, Ohio. Many West Virginians settled in the so-called "Appalachian ghetto," located on the west side of Cleveland. The ghetto received its name because of the large number of migrants who settled there and for the poverty found in the neighborhood. Those people who did not move to the ghetto usually found their way to the suburbs of Cleveland. The primary determinants of whether migrants went to the ghetto or the suburbs were family connections (particularly those pioneers who established beachheads), job skills, and educational level. ${ }^{21}$

Photiadis found that West Virginia migrants shared the common characteristics of age and gender. Most West Virginia migrants were unemployed men between the ages of twenty and forty. In Cleveland, almost twice as many men aged twenty to thirty lived in the Cleveland suburbs than stayed in West Virginia, and there were

\footnotetext{
${ }^{20}$ Thomas C. Hatcher and others, eds., The Heritage of McDowell County, West Virginia 1858-1995 (War, WV: McDowell County Historical Scoiety, 1995), 192.

${ }^{21}$ Photiadis, Social and Sociopsychological Characteristics, 48.
} 
almost four times as many young men in the Appalachian ghetto than in West Virginia. These characteristics are found in Everett Lilly's work on the Clear Fork Valley of Raleigh County, West Virginia. Lilly found that in the Clear Fork Valley, the decision to leave West Virginia took place around the time of a migrant's high school graduation. These migrants also struggled mightily at first. The migrants of Clear Fork had no defined goals other than getting a job, and they had few skills that would help them achieve that one goal. As a result, many of the migrants from the Clear Fork Valley moved into areas similar to the Appalachian ghetto of Cleveland. As one Clear Fork migrant put it when talking about living with his brother in Virginia: “'It was the slums, man. It was just-you just lived in a rat's den. It was so crowded, you know, they had a kid at that time and it was too much so I just packed up and left. I hitchhiked from there to Cleveland, Ohio. I had a brother there." ${ }^{22}$ Lilly recounts that this migrant faced further difficulties in Cleveland with inferior housing and low wages. $^{23}$

Education was a very important adjusting factor for the migrants because it allowed the migrants to adjust to the culture, and determined their economic success. In Cleveland about 33 percent of the migrants living in the Appalachian ghetto completed high school, compared to approximately 60 percent of those living in the suburbs of the city. Because of the poverty found in the ghetto and the correlation between economic success and educational levels, it may be surmised that more people

\footnotetext{
${ }^{22}$ Everett A.Lilly, "Leaving Clear Fork Valley: A Story of Appalachian Migration,” Ph.d. Dissertation, Brandeis University, 1997, 60.

${ }^{23}$ Ibid., 50-51; Photiadis, Social and Sociopsychological Characteristics, 48.
} 
living in the ghetto dropped out of high school than did people living in the suburbs. In both areas, however, roughly the same proportion, about 10 percent, of children dropped out of school. In his study, Photiadis asked several questions about migrants' attitudes towards education. The responses showed that most migrants held education in high esteem, 91 percent of ghetto residents and about 83 percent of the suburban residents of Cleveland disagreed with the statement that most young people get too much education. The miners realized that the problems they faced at home stemmed from depending on mining rather than on education, and so they hoped that their children could receive an education that would help them to make better lives for themselves. ${ }^{24}$

In addition to economic gain, education also allowed Appalachian migrants an opportunity to avoid the social stigma suffered by many poorly-educated people. In the West Virginia coalfields, because male children were expected to enter the mines just as their fathers did, there was little support for any but the most rudimentary education. With a good education, migrant children could enter the dominant society and avoid being seen as ignorant by their peers. Many times, however, the urban school system created more problems for the Appalachian children by misunderstanding their culture; educators often equated slow speech with slow mental activity. Many times, negative images presented in the media and by educators instilled a pattern of failure in children and led to their lowering their expectations. Only by overcoming the shortcomings

\footnotetext{
${ }^{24}$ Photiadis, Social and Sociopsychological Characteristics, 56-61.
} 
found in the urban school systems could migrant children take advantage of available educational opportunities. ${ }^{25}$

Occupational patterns for West Virginia migrants varied. Nearly all male migrants who moved to Cleveland were former miners. The only difference was the level of their skills. Residents of the ghetto had the largest proportion of semiskilled workers, about 67 percent. The suburbanites, in contrast, had the largest proportion of skilled workers, nearly three times that of skilled workers residing in the ghetto. The suburbanites acquired most of their skills after they reached the city. Only about 5 percent of West Virginians living in the suburbs of Cleveland were skilled workers before they left West Virginia. Most were either coal miners or unskilled workers. In 1965, migrant suburbanites reported having lived in Cleveland much longer than those living in the ghetto, about sixty percent had been in Cleveland longer than ten years. ${ }^{26}$

The income earned by West Virginia migrants supported their decisions to migrate. After initial difficulty in finding jobs, most earned more money in the city. Cleveland migrants, for example, had a much higher income than people who stayed in West Virginia. In Cleveland, there was also a differentiation between migrants. While ghetto residents tended to earn higher weekly wages than suburbanites, steady jobs were hard to come by in the ghetto, thus allowing suburban migrants to earn higher

\footnotetext{
25 Johanna S. DeStefano, “Readin', Writin', and Route 23: A Road to Economic but not Educational Success," in Kathryn M. Borman and Phillip J. Obermiller, eds., From Mountain to Metropolis: Appalachian Migrants in American Cities (Westport, CT: Bergin and Garvey, 1994), 162-163.

${ }^{26}$ John D. Photiadis, "Occupational Adjustment in Cleveland," in William W. Philliber and Clyde B. McCoy, eds., The Invisible Minority: Urban Appalachians (Lexington: University Press of Kentucky, 1981), 140-144; Also see: Gene B. Peterson and Laura M. Sharp, Southern Migrants to Cleveland (Washington: Bureau of Social Science Research, 1969).
} 
yearly salaries. Ghetto residents who held steady jobs usually left to settle in the suburbs. Despite the differences within Cleveland, West Virginia migrants were somewhat successful in gaining jobs and adequately providing for their families. ${ }^{27}$

Photiadis's study of West Virginia migrants to Cleveland fits into general trends of Appalachian adjustment to Midwestern cities. As with most internal migrations, Appalachian migrants have gone through a series of adjustment stages in their new homes. The first categorization of the Appalachian migrant was that of transient. Many of the stereotypical views of Appalachian migrants set forth by the Northern media during the early years of migration derived from their idea of the Appalachian as mobile. Because many Appalachians had an important connection to place and made frequent trips home, they were often seen as undependable, shifty, and unreliable. This prevailing image was often corroborated by the fact that migrants often had frequent address changes as they moved numerous times within the port-of-entry neighborhoods, including the Appalachian ghetto of Cleveland. This phenomenon was the result of the Appalachians' search for better jobs and housing within the cities. From a native perspective, the Appalachian migrants were a temporary problem that would be fixed when the migrants returned home. ${ }^{28}$

When it became clear that the migrants had become permanent residents of the destination cities, the identity of the migrants entered a second stage. Social service organizations and governments realized that the Appalachian migrants were not only a

\footnotetext{
${ }^{27}$ Photiadis, “Occupational Adjustment," 147.

${ }^{28}$ Borman and Obermiller, From Mountain to Metropolis, xviii.
} 
temporary problem, but rather were a permanent social problem that had to be dealt with. The social problem approach to Appalachian migrants seems to be the origin of many of the misconceptions about the migrants in the literature. The social problem approach implies that the persons who suffer from poverty only need to adjust their own behavior in order to improve their situations. The theory does not take into account institutional reasons for poverty. The social problem approach characterizes all urban Appalachians as people who live in certain neighborhoods with low levels of educational achievement and job skill. Appalachian migrants spread throughout the destination cities, living in diverse working-class neighborhoods and were not confined exclusively to the "ghettoes." 29

The many stereotypes of Appalachians persisted throughout American culture during the 1950s and 1960s, at least in part, because of the misinterpretation of the migrants and their problems. The caricature of mountaineers seen in the comic strip Snuffy Smith often clouded the way northerners saw the mountaineers. The Chicago journalist Albert Votaw, for instance, warned northerners in Harper's that:

These farmers, miners, and mechanics from the mountains and meadows of the mid-South — with their fecund wives and numerous children - are, in a sense, the prototype of what the "superior" Americans should be, white Protestants of early American, Anglo-Saxon stock, but on the streets of Chicago they seem to be the American dream gone berserk. This may be the reason why their neighbors often find them more obnoxious than the Negores or the earlier foreign immigrants whose obvious differences from the American stereotype made them easy to despise. Clannish, proud, disorderly, untamed to urban ways, these country cousins confound all notions of racial, religious, and cultural purity. ${ }^{30}$

\footnotetext{
${ }^{29}$ Ibid., xix.

${ }^{30}$ Albert N. Votaw, “The Hillbillies Invade Chicago,” Harper's 216 (February 1958): 64.
} 
In short, to Votaw southern migrants were a "disgrace to their race." 31

Votaw was not the only one to characterize the southern migrants in this way. Journalist James Maxwell reported that an Indianapolis native argued that migrants "are creating a terrible problem in our city. They can't or won't hold a job, they flout the law constantly and neglect their children, their moral standards would shame an alley cat. For some reason or other, they absolutely refuse to accommodate themselves to any kind of decent, civilized life." ${ }^{32}$ In Detroit, the citizens of the city responded to a poll during the 1950s which asked what group of people would be the most undesirable to have in the city. The top response to the question was "criminals and gangsters" at 26 percent, however "poor southern whites and hillbillies" drew 21 percent, coming in second. Perhaps surprisingly, this response drew a higher number of votes than drifters, African Americans, or immigrants. Although many of these stereotypes had roots in the years prior to the Appalachian migration, the social problem approach to migration helped to strengthen and solidify the generalizations. ${ }^{33}$

Despite the many problems inherent in the migratory experience, Appalachian migrants made remarkable adjustments. One of the ways the migrants adjusted was through transplanting some of the traditional aspects of their culture. Two excellent examples of this are country music and religion. Country music developed as a regional musical genre in the southern Appalachians that combined popular music with

\footnotetext{
${ }^{31}$ Ibid., 67.

32 James A. Maxwell, "Down from the Hills and into the Slums," Reporter 15 (13 December 1956): 2728.

${ }^{33}$ Detroit Free Press, 18 November 1952, quoted in Berry, Southern Migrants, Northern Exiles, 176.
} 
traditional lyricism and instrumentals. Many of the Appalachian migrants brought this music with them and, in a sense, are responsible for the national popularity of country music today. The second important adjustment tool for the Appalachian migrants was through their traditional religious activities and institutions. Most of the Appalachian migrants were not comfortable in the mainline Protestant and Roman Catholic churches found in the destination cities. Rural Appalachians traditionally felt most comfortable in evangelical churches that were an offshoot of the revivalism that began during the Second Great Awakening of the nineteenth century. As a result, Appalachians traditionally flocked to churches that preached individual salvation and a literal interpretation of the Bible, such as Baptist and Pentecostal churches. ${ }^{34}$

The migrant churches played an important role in the adjustment of the migrants for several reasons. First, the churches served the obvious spiritual needs of the congregation, providing comfort in a period of adjustment characterized by great stress. Second, the churches provided comfort and advice for the migrants with their everyday problems that everyone goes through, including problems with work and the family by providing social services to the congregation. Third, the churches provided the members a connection to home. For example, the churches might provide summer trips or provide for burials back in the mountains. Donald Bowles, the migrant who moved from McDowell County to Michigan in 1965, became involved in evangelical churches in the Flint area after they moved to the region. The church provided the Bowles

\footnotetext{
${ }^{34}$ William David Worley, "Social Characteristics and Participation Patterns of Rural Migrants in an Industrial Community" (M.A. thesis, Miami University, 1961), 82-84; Feather, Mountain People in a Flat Land, xx; Wilson, "Adjustment Process in Cincinnati," 92-101.
} 
family a social network that counterbalanced the uncertainty of relocation. ${ }^{35}$ The churches also had an important effect on the culture of the destination cities. The migrants brought new denominations, the Southern Baptist Convention for example, into the culture of the North. By doing so, the migrants played an important role in the diversification of northern culture and made the South (broadly defined) into a less distinct culture. $^{36}$

The Midwest was not the only destination for Appalachian migrants. Many Appalachians also made their way into the Baltimore metropolitan area. An important question derives from this fact; did Appalachian migrants to Baltimore have similar or different experiences from the migrants to the Midwest? Although Midwestern migration began before the "great migration" of the 1950s, it did not explode until the decline of employment in the coal industry after World War II. In Baltimore, the bulk of the migration occurred during World War II as Appalachian migrants moved to the Baltimore area to work in the defense factories. Thaddeus Smith, in his work Where there are no Mountains, discusses the role of Appalachian culture and migration in Baltimore during World War II. Although his work has some serious problems in perpetuating common stereotypes of Appalachians, Smith does give a solid overview of what might be the forgotten Appalachian migration. The region along the Chesapeake

\footnotetext{
${ }^{35}$ Bowles interview.

${ }^{36}$ Wilson, "Adjustment Process in Cincinnati," 92-101; Worley, "Social Characteristics and Participation Patterns," 82-84; Feather, Mountain People in a Flat Land, xix-xxi; Also see: Deborah Vansau McCauley, Appalachian Mountain Religion: A History (Urbana: University of Illinois Press, 1995), L.H. Morre, The History of the Southern Baptists in Ohio (Columbus: State Convention of Baptists in Ohio, 1979), and John D. Photiadis, ed., Religion in Appalachia (Morgantown: West Virginia University Press, 1978).
} 
coast in northeastern Maryland, which was called the industrial war strip, was forty miles of defense factories in Cecil, Harford, and Baltimore counties. This region included Elkton in Cecil County, whose population increased from 4,000 in 1940 to 11,000 in 1943, and Aberdeen in Harford County, home of the Army's Aberdeen Testing Complex, as well as Baltimore County. ${ }^{37}$

The migrants to the industrial war strip came from many different Appalachian regions, including western Maryland, West Virginia, and Virginia. In northeastern Maryland, about half of the migrants worked for the Army in Aberdeen and lived in military housing in the region. Those who did not live in military housing moved to other local communities and were lucky to do so. There were numerous migrants who did not succeed in finding quality permanent housing which forced them to either rent temporary, makeshift housing or to live in their cars at night. One of the primary reasons for this problem was the high cost of living in northeastern Maryland. Many migrants simply could not afford the high rents that were so prominent in that region. ${ }^{38}$ Baltimore enjoyed a period of prosperity even before World War II, as companies in the city received orders from overseas for war materiels. In the first two years of the European War, over 100 factories either started or expanded existing operations. The location of the city was also important in explaining its large growth rate. The city was the nation's second largest port, had extensive infrastructure for improved communication and transportation, and was the closest industrial center for

\footnotetext{
${ }^{37}$ Thaddeus Smith, "Where There Are No Mountains: Appalachian Culture and Migration to Baltimore," (Ph.D. Dissertation Brown University,1987), 157-158; S.G. Arthur, "How the War Ran over Elkton," Nation's Business 48 (October 1945): 29.

${ }^{38}$ Smith, "Where There Are No Mountians," 158.
} 
much of the Southeast, which put Baltimore in a situation where it could be an important destination for migrants looking for good jobs. Between 1940 and 1943, Baltimore grew by 119,000 people, which was over 75 percent of the entire state's population increase during the same period. Baltimore was also the center of the industrial war strip because most of the important government contracts went to the city. $^{39}$

The extensive expansion of industry in Baltimore obviously drew many migrants into the city, as shown by the population increase during the early years of the 1940s. One question remains, however. How many migrants specifically came into the region? In 1940 alone, over 61,800 new migrants entered Baltimore, mostly from small towns and country settings in the South, particularly North Carolina, Virginia, and West Virginia. Like the migration to the Midwest, migration patterns were evident in the migration to Baltimore. Geography played an important role in migrants' decision making process as to which destination city they would choose. Baltimore was in close proximity to certain areas of Appalachia, particularly Virginia and West Virginia. Coupled with the fact that there were many different defense industries located in the industrial war strip, it is easy to see why so many migrants chose the Baltimore region. If a migrant could not find work in one plant, he or she could try another. Also, high wages characterized the defense industries, naturally drawing migrants to the region.

\footnotetext{
${ }^{39}$ Ibid., 158-161.
} 
After Pearl Harbor, Baltimore's war industries were in desperate need of workers, serving as a migratory "pull' bringing migrants to the city. ${ }^{40}$

The Appalachian migrants to Baltimore basically were invisible because they accounted for only a small percentage of the total number of migrants coming into the city to work. Migrants came from areas throughout the eastern region of the country, including New York, New Jersey, Pennsylvania, and Delaware. Appalachian migrants, therefore, only accounted for about 6.7 percent of migrants to Baltimore in 1940. A plurality of the Appalachian migrants, 35 percent, came from West Virginia. All areas of the state were represented, including the southern coal fields. As with the Midwestern migration, the evidence suggests that these migrants to Baltimore did not possess the adequate skills for the industrial occupations of the region. For example, Smith notes that over half of the Appalachian migrants came from a coal or farming background. As a result, Smith argues that these workers were in low-skill positions at home and did not adjust well to their new jobs. ${ }^{41}$

As with the Midwestern migration, the age of the migrants to Baltimore was very young, an average of 25 . Over half of the migrants were younger than 34 . The demographic characteristics of the migrants also suggest that they were highly mobile. About half of the migrants who came to the city alone left a spouse or children behind when they moved to Baltimore. The rest were single men These statistics characterized all of Baltimore’s migrants, not just Appalachian migrants. Smith makes an indirect correlation with Appalachian migrants by studying the Appalachian

\footnotetext{
${ }^{40}$ Ibid., 161-162; George H. Callcott, Maryland and America: 1940 to 1980 (Baltimore: The Johns Hopkins University Press, 1985), 40.

${ }^{41}$ Smith, "Where There Are No Mountains," 164.
} 
population during the same period. Smith notes that during this period the under 34 population was declining in Appalachia, while growing significantly in Baltimore. He makes a similar correlation with the number of single individuals in Appalachia decline in comparison with the number of single individuals increasing in Baltimore. ${ }^{42}$

Although there were a large number of migrants working in the defense plants of Baltimore, there continued to be a significant labor shortage suffered by the employers of the region. The reason for the shortages stems from many of the migrants being unskilled laborers who had to be trained for defense jobs. The government attempted to implement training programs to improve the labor skills of the migrants and rectify the labor shortage inherent in the defense industry of the area. Smith argues that the success of the program was mixed. The competition among migrants for the jobs revolved around skill requirements, sex, and race. White females had the most success in finding work, primarily because of employers' belief that women had a better dexterity in their movements and high-quality eyesight. White males had few problems as well, although African American workers found it extremely difficult because of discrimination against them by employers. Employers actually asked for certain groups, either by race, religion, or ethnicity. As a result, blacks had a hard time finding work in the defense industries. ${ }^{43}$

There were many ways in which migrants were mobile. Migrants moved from job to job within Baltimore in search of higher paying jobs or jobs which had the

\footnotetext{
${ }^{42}$ Ibid., 165.

${ }^{43}$ Ibid., 166-168.
} 
potential to become permanent after the war. Sometimes the migrants heard rumors of work closer to home and would leave as a result. This was an acute problem for the city. It was estimated that an average of 2000 workers left the city weekly during 1943. The stereotype of the shiftless, undependable Appalachian migrant became more prevalent in the press and among the native Baltimoreans as the war progressed. In July 1943, an editorial in the Baltimore Sun said the following about the migrants:

When they get here they find that Baltimore isn't the Utopia they had come to expect. There they find the big wages. But they also find that jobs though not necessarily bad, ain't soft, either. And they find that living conditions are pretty dreadful and transportation to and from work is a big headache. So, after they've cashed a few checks they start to get fed up, or they hear about some other war industries near the place where they came from, or they just get homesick. One day, right after payday, they don't show up for work. They buy a ticket and go back home. ${ }^{44}$

To the city leadership, the Appalachian migrants remained an invisible population. The group not only constituted an extremely small percentage of the city's migrant population, there were also no civic groups to lobby for the benefit of the urban Appalachians. Furthermore, the migrants' rural heritage set them apart from the other whites in the city. The migrants, therefore, had little sense of community in Baltimore. The Appalachian migrants seemed to be part of a larger problem, that of a city struggling to deal with a significant group of temporary workers. And there were plenty of problems associated with the migrant workers. The city had become used to the transients during the years of the Great Depression because Baltimore was a

\footnotetext{
${ }^{44}$ Baltimore Evening Sun, 22 July 1943.
} 
preferred destination for migrants during those years. Many of the workers went straight to the factories or to the employment service seeking work. ${ }^{45}$

Many migrants had a harder time finding decent housing than in finding work. Although the city leaders argued that there was no housing shortage in Baltimore, many of the Appalachian migrants would argue otherwise. There was a housing shortage as evidenced by the fact that many Appalachian migrants lived in their cars or in other shanty, makeshift homes. For example, a migrant family from Tennessee had to live in an abandoned hot dog stand without electricity or plumbing. The wife said, "'It's the best we can do. We couldn't find any other place we could afford. You can't spend all your money on a place to live when you don't know how long you'll be working.",46 Some Appalachians had to move outside of the city to find an affordable place to live. Families were not the only ones to feel the housing crunch. Even single men who had come to Baltimore had issues with the available housing. One said: "Who wants to live in a one-room cabin with three other guys?"47 Part of the problem with housing resulted from the fact that Baltimore's defense industries failed to estimate the labor needs of their factories. This failure made it difficult for city leaders to successfully implement a long-term housing plan. The building of private homes was not practical because private investors would not want to build homes for defense workers because most of the defense workers were transient and would not become a permanent part of the community. So, the question remained; how would Baltimore meet the housing

\footnotetext{
${ }^{45}$ Smith, "Where There Are No Mountains," 170-171.

${ }^{46}$ Baltimore Evening Sun, 28 February 1941.

${ }^{47}$ Ibid.
} 
needs of its migrant workers? The solution was a temporary one. The government brought in temporary housing, in the form of trailer parks and dormitories. These temporary structures could then be removed when the war was over and the land could revert to its original use. The plan was designed to meet the needs of the city's unstable work population without requiring the assistance of private investment. ${ }^{48}$

Despite the efforts of the government to meet the city's housing needs, the available housing in Baltimore remained in terrible shape. Only about 50,000 people lived in defense housing, the rest lived in the older residential neighborhoods of the city. Appalachian migrants seem primarily to have lived in these older sections, where the conditions ranged from comfortable to crowded and terrible. The city's Housing Authority conducted a survey and found that fifty-eight families lived on one block in South Baltimore. Of these families, over half lived in unsafe housing, with only five families having central heating. The standard occupancy rate for the city of one and a half people per room was exceeded by many of these families. Twenty-five had densities of three or more; ten had densities of five or more. Despite the problems facing many Appalachian migrants in housing, some believed life in Baltimore was a luxury compared to what they had come from. Many more, however, hated life in the city. Smith notes that migrants had two major complaints, the high cost of living and the lack of privacy. ${ }^{49}$ One Appalachian noted, “'Our young people don't have many

\footnotetext{
${ }^{48}$ Smith, "Where There Are No Mountains," 171-173.

${ }^{49}$ Ibid., 173-175; Deborah Weiner, "From Modern Victory to Postmodern Defeat: Two Baltimore Housing Projects," The Maryland Historian 26, no. 2 (Fall/Winter 1995): 27-28.
} 
dates; there's hardly any room for any visitors in the trailer, and the front steps are so narrow we have to line up on them duck-fashion.",50

Native Baltimoreans also treated the migrants in similar ways to native Midwesterners. At best, the native population of the city regarded the Appalachian migrants as different; at worst, the natives saw the migrants as a drag on the city. Many migrants saw the natives as being cold and unfriendly. As a result, many found it difficult to adjust to life in the city. Part of the reason for the animosity of the native Baltimoreans was because of the building of temporary housing in the older residential neighborhoods of the city. Another reason for the cold attitude from the natives was simply because of a feeling of overcrowding. Unlike the rest of the industrial war strip, Baltimore had no room in which to expand. Finally, the differences in culture help to explain why Baltimoreans considered the Appalachian migrants to be different based on differences in accents and behaviors. Despite the disdain shown by much of the native population, many churches and other social organizations provided services to migrants in an effort to soften the adjustment to urban life. Many migrants, however, did not take advantage of either the spiritual aspects of the church or the social welfare programs. A major reason for this attitude is the migrants' self-identification as a temporary citizen of Baltimore. Because they were not permanent, the migrants were not interested in becoming part of a church community. ${ }^{51}$

\footnotetext{
${ }^{50}$ Baltimore Evening Sun, 30 July 1943.

${ }^{51}$ Smith, "Where There Are No Mountains," 176-178.
} 
According to Smith, when the war was over most of the migrants returned home as the defense industries demobilized. Most of the migrants, never fully becoming accustomed to life in the city, were pleased to be returning home. Baltimore did not turn out to be the city of opportunity many thought it would be and, with the loss of their defense jobs, many seized the chance to go home. Throughout the city, migrants vacated their apartments on a massive scale. When the migrants left the city, there was also little reason for the government to continue running the temporary housing. The housing projects, trailer parks, and dormitories were de-programmed by the federal government and the land was returned to its original use. As the Baltimore Evening Sun described the scene in August 1945: “'Debris is scattered over the grounds of the projects...casted off materials have been thrown up on the roofs of structures. Window glasses are broken." ${ }^{, 52}$

There are examples, however, of Appalachian migrants who did not return to the region. My great aunt and her husband moved to Elkton, Maryland (Northeast of Baltimore on the Delaware border) around the time of World War II. This served as a potential beachhead for other members of the Myers family. In fact, my grandfather, Charles F. Myers, went to Maryland looking for work in the mid-1950s during a slow time in the mines; his wife, Betty Rae Myers, was with him during this period as well, leaving their three children with their grandparents. Although Charles Myers

\footnotetext{
${ }^{52}$ Baltimore Evening Sun, 23 August 1945.
} 
eventually returned to his job for U.S. Steel, his sister and brother-in-law remained in Maryland, making it their permanent home. ${ }^{53}$

The pattern of Appalachian migrants returning home, as shown by Smith's work on Baltimore, was a small, yet significant characteristic of the general Appalachian migration. Some migrants realized that life outside of the mountains did not offer the same quality of life as living back home. This was either a very small group of people or a group without a recorded history, however. The migration literature has studied the difficulties and successes of permanent migrants rather than the so-called "birds of passage," those migrants who had no intention of staying in the destination city. Although Smith's perception of Appalachian migrants to Baltimore suggests that most of the migrants to that region were "birds of passage," it seems that many more either stayed in the destination city or moved with every intention of staying there for the work. If this is the case, what expectations did the return migrants have when they came home? Did their experiences meet those expectations? In many ways, the success of the return migrants seem to be directly connected to the amount of success enjoyed in the destination cities. ${ }^{54}$

Lilly, in his study on migration from Clear Fork Valley, recounts a few stories of migrants who returned to the mountains. One couple, in particular, tried to return to

\footnotetext{
${ }^{53}$ Dennis Myers, interview by the author, 17 April 2008, Muncie, Indiana, tape recording, in author's personal collection.

${ }^{54}$ Shirley L. Stewart and Connie L. Rice, “The 'Birds of Passage' Phenomenon in West Virginia's OutMigration," in Phillip J. Obermiller, Thomas E. Wagner, and E. Bruce Tucker, eds., Appalachian Odyssey: Historical Perspectives on the Great Migration (Westport, CT: Praeger, 2000), 39; John Bodnar, The Transplanted: A History of Immigrants in Urban America (Bloomington: Indiana University Press, 1985), 52.
} 
West Virginia in the early 1980s from Dayton, Ohio. Failing in their attempt to live back home again, the couple decided to return to Dayton. Although Lilly does not tell of the couple's success in Ohio before their attempt at moving back to the mountains, only by moving back to Ohio did they find economic success. Another example from Lilly's work concerns a couple who came back after many years away. This couple had struggled when they first moved from the mountains, but eventually had achieved a comfortable existence in their new home. The mountains, however, continued to beckon. This feeling of connection to place, combined with a concern for aging parents, led the couple to return permanently to Clear Fork. For this couple, the experience of coming back home was rewarding because it allowed their parents the opportunity to spend their twilight years with the children. ${ }^{55}$

Many mountain migrants also had the desire to return home after retiring from the jobs that took them out of Appalachia. Carl Feather tells the story of Ralph and Emma Bonham, native West Virginians who moved to Northeastern Ohio in 1955. After working for twenty-eight years, Ralph retired as a pipe fitter for Union Carbide Metals. They raised four children in Ohio who, when they were grown, went to college and moved out of the area. The fact that the Bonhams no longer had connections to Northeastern Ohio through their children, coupled with the deaths of numerous relatives and one of their children, persuaded them to move back to West Virginia. The account of their experiences does not show the Bonhams' level of satisfaction, however the couple did make the conscious decision to return and take their chances at home. ${ }^{56}$

\footnotetext{
${ }^{55}$ Lilly, "Leaving Clear Fork Valley," 72-73.

${ }^{56}$ Feather, Mountain People in a Flat Land, 223-226.
} 
No matter the reasons for the return migration to West Virginia, the fact remains that many Appalachians decided that only the mountains could offer them the quality of life they so desperately wanted.

The loss of so many people from McDowell County as a result of the massive out-migration of the 1950s and 1960s left a lasting mark on the county. The county lost its best and brightest citizens, as well as the unique sense of community that characterized the coalfield regions of the twentieth century. The out-migration from McDowell County was part of a general movement of people out of Appalachia during the post-war period. Thousands of Appalachians, facing the prospects of unemployment and potential poverty, made the conscious decision to move in order to find work. There were two primary streams of migration from McDowell during the 1950s and 1960s, one to the Midwest and one to the Baltimore region of Maryland. The literature of migration seems to be convoluted in regards to the success rate of the Appalachian migrants in their new homes. Some of the literature argues that Appalachian migrants struggled during the adjustment period in their new homes. However, much of the recent literature discounts this position. Many Appalachian migrants made good lives for themselves in their new homes. The literature does not deal only with the economic success, or lack thereof, of the migrants, but also the social adjustment of the migrants. In this instance, the literature seems to be more in agreement. Because of cultural differences, Appalachian migrants often found it difficult to adjust to their new, urban homes. They faced humiliation and ridicule at worst from natives of the destination cities; at best, the migrants had a feeling of abandonment and alienation. As a result of the quality of life issues plaguing them, a 
small but significant group of migrants decided to return to the mountains. A larger group, however, succeeded and made lives for themselves in their new homes.

Although many would have liked to have returned, the economic situation at home would not allow it. Conditions within McDowell County deteriorated rapidly until there were few people who could be characterized as success stories. Life at home consistently deteriorated as the coal industry became less and less dependable for the county's livelihood. Many who stayed, or were forced to stay, found themselves mired in poverty with little chance for economic success. 


\section{Chapter 6 \\ A World of Contrasts: McDowell After Deindustrialization}

By the end of the 1950s, it was clear that deindustrialization caused serious structural problems in the Appalachian economy. Many individuals who failed to migrate found themselves without work, as the coal industry closed mines and began to employ machinery in order to decrease labor costs and increase production. By the early 1960s, McDowell County was one of the poorest counties in the nation, with socio-economic conditions that rivaled some third-world countries. Conditions in some areas were so poor that John F. Kennedy, campaigning in the 1960 Democratic presidential primary, made a promise to implement policies to fight poverty, if he were elected to the presidency. His promise marked the beginning of the War on Poverty of the Johnson administration of the mid-1960s. ${ }^{1}$

After 1963, the economic condition of the region improved slightly. The coal industry stabilized and the unemployment rate decreased somewhat. Part of the reason for this improvement stems from the region's attempt to diversify its economy.

Statistics show that between 1963 and 1967 the level of employment in other economic endeavors, including manufacturing, trade, and service industries, increased as employment in the coal industry declined. In McDowell County, service industries became a bigger part of the economy since the population remaining in the county was older with the out-migration resulting from deindustrialization. Many of the younger generation who remained also required governmental support in the form of AFDC and

\footnotetext{
${ }^{1}$ See: Daniel B. Fleming, Kennedy vs. Humphrey, West Virginia, 1960: The Pivotal Battle for the Democratic Presidential Nomination (Jefferson, NC: McFarland, 1992).
} 
food stamps. Therefore, members of the community who received an education could potentially get a job and remain in the county. ${ }^{2}$

A good indicator of the slightly improved economic conditions in Appalachia is the change in the per capita income of the region in relation to the rest of the United States. In 1962, Appalachia's per capita income was 76.9 percent that of the rest of the country. In 1967, the per capita income of Appalachia had risen to 77.9 percent of the national income. Also, unemployment in Appalachia as a region declined during the same period. In 1963, the national rate of unemployment was 5.7 percent. In comparison, the Appalachian unemployment rate was 8.1 percent for the same year. Although the Appalachian unemployment rate remained 30 percent higher than the national average the total unemployment rate for the region fell significantly during the four year period in question. In 1967, the national unemployment rate stood at 3.8 percent while the Appalachian rate was 4.6 percent. It is very difficult, however, to understand the conditions of every locale in Appalachia when discussing regional statistics. A more telling picture lies in the statistics for Central Appalachia. Although Central Appalachia did see an improvement in the rate of unemployment for the period, the unemployment rate was still extremely high in comparison with the rest of the region. In 1966, the unemployment rate in Appalachian Kentucky was 9.8 percent; in West Virginia, the rate stood at 6.4 percent. $^{3}$

\footnotetext{
${ }^{2}$ Richard A. Couto, An American Challenge: A Report on Economic Trends and Social Issues in Appalachia (Dubuque, IA: Kendall Hunt Publishing Company, 1994), 39; Isabell V. Sawhill, "Poverty in the U.S.: Why Is It So Persistent?" Journal of Economic Literature 26 (September 1988): 1112-1113.

${ }^{3}$ Couto, An American Challenge, 90.
} 
An important development during the mid-1960s that helps to explain the somewhat improved economic conditions in Appalachia was the creation of the Appalachian Regional Commission (ARC). The ARC was extremely important because it pumped an immense amount of money into the region. The federal money distributed through the ARC provided funding for infrastructure and public sector employment for the people of the region. Another important aspect of the ARC was that it focused national attention on the region, and then forced policymakers to address problems that befell the region. A problem with the ARC, however, was that the agency provided money primarily to the most economically-advanced regions, which explains why much of Central Appalachia continued to lag behind the rest of the region. Although money is important to improve the infrastructure of Appalachia, the ARC was also created under a false impression of Appalachia's "otherness." Therefore, the ARC was a test of the modernization theories, including culture of poverty theory. The major premises of the ARC followed the major premises of modernization theory. First, the ARC was founded on the belief that Appalachia was a depressed region because of its physical, cultural, and economic isolation; second, the ARC contended that isolation of the region not only led to economic depression, it also inhibited economic growth that could bring the region out of this depression. Third, the ARC was founded on the belief that economic growth can benefit all the citizens of the Appalachian region. As a result, the ARC thought it would eradicate poverty throughout the region by promoting economic growth and causing economic development. $^{4}$

${ }^{4}$ Ibid., 58, 91. 
Because of the inherent, fundamental beliefs surrounding the ARC, the money pumped into the region to build the infrastructure was designed not only to improve the economy of Appalachia but also to decrease the "isolation" of the region. In addition to building up infrastructure, the ARC was required to use its funding for industrial subsidies. As the ARC legislation stated, the money was to go to "investments...in areas where there is a significant potential for future growth... where the expected return on public dollars will be the greatest. ${ }^{, 5}$ The idea was to spread the money throughout the region, creating jobs and leading to the eradication of poverty. The problem is that the subsidies to business failed to do much to eradicate poverty in the region. A 1969 report found that despite the massive amount of money sent into the region by the ARC and other programs of the War on Poverty, capital continued to flow out of the region; in fact, capital was leaving the region at a faster rate, probably because of the industrial subsidies provided by the government. ${ }^{6}$

Another example of the failure of modernization theory to explain fully and to provide solutions for poverty in Appalachia was that the quality of life in the region actually diminished even during years of improvement in economic indicators such as per capita income. Throughout the 1970s (which was a decade of economic growth as will be discussed below) economic growth was unevenly distributed throughout Appalachia. For instance, two-thirds of the counties in Appalachia declined economically between 1970 and 1985 despite the influx of money into the region. This

\footnotetext{
${ }^{5}$ Quoted in Ada F. Haynes, Poverty in Central Appalachia: Underdevelopment and Exploitation (New York: Garland Publishing, 1997), 58.

${ }^{6}$ D.N. Rothblatt, Regional Planning: The Appalachian Experience (Lexington, MA: Heath Lexington Books, 1971), 63-64; Haynes, Poverty in Central Appalachia, 58.
} 
development proves that poverty in the region is not because of a lack of development but because of the type of development in the region. ${ }^{7}$

Of course, the development in the Central Appalachian region has focused around the coal industry. This is the single biggest problem facing McDowell County. Because of the lack of diversity in the economy of the region, all of the people of McDowell suffered when the coal industry declined in the 1950s and 1960s. Furthermore, because of the lack of diversity in the economy, much of Central Appalachia did not enjoy much of an improvement in the economy during the improved economic years of the mid-1960s. One question remains, however. How did the failure to improve the economy of the county happen? How can there be such wealth in natural resources and such poverty at the same time? Why was there no move to diversify the economy by bringing in other industries to make up the slack? To understand this question, an examination of the landowning patterns is necessary.

The biggest indicator of the economic imbalance found in many Appalachian counties is the comparison between large and small landowners. As one Appalachian said: “"The biggest problem down here is that so many of the mines are operated by large corporations which are so far away from the coalfields. Their sole concern is the balance sheet. No humane system could possibly develop from them."” ${ }^{8}$ The statistics seem to bear out this resident's opinion. In the coalfield counties of Central Appalachia, absentee corporations own up to 85 percent of the total land available for

\footnotetext{
${ }^{7}$ Haynes, Poverty in Central Appalachia, 58-59.

${ }^{8}$ Kenneth Mirvis, “A Phenomenological Analysis of Two Appalachian Coal Producing Counties," Ed.D. dissertation, Boston University, 1981, 75.
} 
use. In many ways, the prevalence of absentee ownership seems to support much of dependency and internal colonial theory. Because these outside landowners control so much of the land, Appalachians are forced to depend on the landowners for their livelihood. Since there was no available land for locals, Appalachians basically became colonial subjects of the coal industry. ${ }^{9}$

What is the exact scope of the absentee landholding in Central Appalachia? In the early 1980s, the twenty largest landowners controlled 4.5 million acres of land. Of these twenty companies, only three had headquarters in Appalachia, with only one coming from the coalfields. These companies that owned the land in Central Appalachia usually mined very little coal. Instead the companies usually leased the land to the mining companies. Although the mining companies did employ workers in the region, the landowners did not employ enough Appalachians to make a difference to the people. Therefore, much of the money made from the vast natural resources of Appalachia passes to the outside interests, without ever making it into the hands of the Appalachian people. ${ }^{10}$

The unequal land holding pattern evident in the Central Appalachian region also led to another problem, an unequal tax structure. In many locales, the mineral wealth of the land is not taxed, or taxed at an extremely low rate relative to its value. Justification for this trend comes from two sources. First, unused land is not productive. Since much of the land owned by the out-of-state corporations is not leased

\footnotetext{
${ }^{9}$ Ibid.

${ }^{10}$ Ibid., 75-76; John Gaventa, "Land Ownership and Productivity," in Helen Lewis, ed., Coal Productivity and Community: The Impact of the National Energy Plan in the Eastern Coalfields (unpublished, 1978), xiv.
} 
for farming or residential purposes, it is very difficult to tax the land at a fair rate based only on surface activities. Second, the mineral wealth of land is difficult to determine; in some locations the mineral wealth is not even taxed. As a result, gross inequities developed in the tax structure, further affecting the people of the region. For example, in the coal counties of Tennessee in 1971, nine companies owned 34 percent of the land, 80 percent of the mineral wealth, and only paid 3.6 percent of the local property taxes. $^{11}$

There is another problem that results from the absentee ownership of land in Appalachia. Because the out-of-state companies own so much of the available land in Central Appalachia, these companies have immense power in deciding the economic characteristics of the region. Companies that might be interested in relocating to Appalachia have a very difficult time in acquiring adequate land to build their facilities. This problem is especially acute for those industries that might be competitive with coal and timber. One example of the problem is cited by Mirvis. A community leader in Harlan County, Kentucky spoke of his experience with the issue of diversification:

I was working for the CAP agency (Community Action Program). A large corporation called and told us that if we could find a suitable spot for a factory they would build one here. We went out and promptly found them three suitable spots, each one with immediate ninety-nine year leases. They came in, saw the spots were suitable, and before they had a chance to complete the lease, the coal companies bought the land. ${ }^{12}$

The problem does not just affect the diversification of the economy; it also impacts public service facilities. In most instances, community organizations must gain

\footnotetext{
${ }^{11}$ Gaventa, "Land Ownership and Productivity," xvi; Mirvis, “A Phenomenological Analysis," 76.

${ }^{12}$ Mirvis, “A Phenomenological Analysis,” 78.
} 
permission from the landowners in order to build facilities that would benefit the community. For example, in 1972 a group of residents in Tennessee asked an English company, the American Association, for one-half acre to build a community health center. The American Association owned over 50,000 acres of land in Tennessee, yet the company refused to allow the construction of the health facility that would benefit the residents of the region greatly. As a result, it is clear that not only do the people suffer from the lack of diversification in the economy because of fewer employment options, they also suffer from poor social services, such as education and health care, because of absentee ownership of the land. ${ }^{13}$

Despite the economic problems facing McDowell County, many coal companies attempted to put a positive spin on the situation. In 1965, the United Pocahontas Coal Company sent a letter to their miners which exuded optimism for the future:

United's coal tonnage and store volume have almost doubled as a consequence (of mechanization). Such expansion certainly serves to express United's faith in the coal industry's future and in the people who are United Pocahontas.

Of course, the material progress made has brought with it serious problems, many of which are far from being solved as yet. However, we are confident that, with your continued loyalty, cooperation, and help, substantial progress will be made in 1966 in solving these difficulties. ${ }^{14}$

\footnotetext{
${ }^{13}$ Ibid.; John Gaventa, "Property, Coal and Theft," in Helen Lewis, Linda Johnson, and Don Askins, eds., Colonialism in Modern America: The Appalachian Case (Boone, NC: Appalachian Consortium Press, 1978), 152.

${ }^{14}$ Letter from Ronald C. Laither to the miners of the United Pocahontas Coal Company, December 15, 1965, United Pocahontas Coal Company Archives, West Virginia Regional History Collection, West Virginia University, Morgantown.
} 
This optimism of the United Pocahontas Coal Company executives was unfounded. Conditions continued to deteriorate throughout the 1960s in the county, forcing residents to either migrate or face the prospect of poverty.

There are not only economic reasons for the lack of diversification in Central Appalachia, but also political reasons. State governments, from the earliest years of the industrial period, usually supported the coal industry in its efforts to establish economic hegemony over the Central Appalachian region. In the early years, state support focused on the development of transportation networks (i.e. railroads) and the establishment of an adequate labor pool to foster mineral extraction. As the years passed, state governments, particularly in West Virginia, have continued to support the coal industry to the detriment of the people living in the region. One example of this support is the tax policies as noted above. Another example is the failure of political leaders, both local and statewide, to realize the boom and bust nature of the coal industry and to use their political power to realize the important economic diversification of the region that would have improved conditions and the lives of the people. $^{15}$

The years between 1967 and 1977 can be characterized as years of significant economic improvement in Central Appalachia. The decade can be further subdivided into two periods, 1967 to 1972 and 1972 to 1977 . Both periods were years where the economy improved throughout the region, however the difference is the reason for the improvement. Between 1967 and 1972, the major change that occurred was an

\footnotetext{
${ }^{15}$ Haynes, Poverty in Central Appalachia, 55. See also: John Gaventa, Power and Powerlessness: Quiescence and Rebellion in an Appalachian Valley (Urbana: University of Illinois Press, 1980).
} 
increased demand for coal. This increase occurred for several different reasons. First, as the Vietnam War escalated during the late 1960s, the demand for coal increased as military orders rose significantly. War was not the only reason for the increase in demand for coal. Across the board, both foreign and domestic orders for coal rose at a rapid rate. Appalachian coal accounted for about 95 percent of all national coal exports. Domestically, coal use was increasing nationwide. During the first half of the 1960s, the United States increased its consumption of coal by an average rate of 3.6 percent each year. During the second half of the decade, the average annual increase had risen to 5.0 percent. The late 1960 s was a period of boom in the coal industry as demand exceeded supply for the first time in many years. Because of the increased demand, among other factors, there was a shortage of trained workers for Appalachian coal mines. Miners were able to negotiate and strike for better benefits, including wild cat strikes designed to win black lung benefits. This labor militancy was a result of both the economic improvement of the age and the legacy of the coal industry in the coalfield communities of Appalachia as discussed below. ${ }^{16}$

The period between 1973 and 1977 is best understood within the context of international events. The 1973 oil embargo sent shockwaves throughout the world economy. In the United States, the overwhelming dependence on oil led to serious inconveniences at best and outright crisis at worst. Looking for alternative fuel sources, American business began looking at coal once again to meet the energy needs of the nation. With the rise in demand that resulted from the energy crisis, the price of coal

\footnotetext{
${ }^{16}$ Haynes, Poverty in Central Appalachia, 91-92. See Appalachian Regional Commission, "The Demand for Energy and Appalachia's Coal," Appalachia 5, 4 (1972): 1-5 and Appalachian Regional Commission, "Appalachia: Twenty Years of Progress," Appalachia 19, 2-4 (1986): 8-15.
} 
rose substantially, over 117 percent between 1963 and 1973. The primary benefit of this improvement in conditions in the coal industry was the expansion of the industry in McDowell County. Companies hired many more employees through expanding their operations and new mines were opened throughout the county. The job climate was the strongest it had been in over twenty years in the mid-1970s. The end result of the expansion of the coal industry that resulted from the energy crisis was an increase in the average per capita income in Appalachia. As Miernyk noted in the journal Appalachia in 1975: "Throughout the present recession personal income in the major Appalachian coal-producing states has increased more rapidly than that of the nation as a whole....While other factors might be partly responsible for this favorable showing, rapid increases in coal revenues are undoubtedly the most important cause." ${ }^{\prime 17}$ By 1975, the per capita income of Central Appalachia had risen from 58.5 percent to 69.4 percent of the national level, showing some improvement in the relative economic position of the region. $^{18}$

Per capita income is not the only appropriate indicator to examine in trying to develop an overall view of the decline in poverty in the Central Appalachian region. For the period 1970 to 1990, Appalachia did a much better job in reducing poverty than the rest of the nation. Of course Appalachia had a much higher rate of poverty than the rest of the country, allowing for much more room for improvement. For example, 17.7 percent of the people in Appalachia lived in poverty in 1970. By 1980, this percentage had fallen to 13.7 percent. The national rate decreased from 13.3 to 12.4 percent during

\footnotetext{
${ }^{17}$ W.H. Miernyk, "Coal and the Future of the Appalachian Economy," Appalachia 9, 2 (1975): 29-35.

${ }^{18}$ Haynes, Poverty in Central Appalachia, 94-95; Miernyk, "Coal and the Future," 29-35.
} 
the same period. Of the three subregions within Appalachia, Central Appalachia had the largest decrease in the poverty rate during the 1970s. In 1970, 34.0 percent of the population in Central Appalachia lived below the poverty line. By 1980, the percentage had fallen to 22.3 percent. It is clear that the 1970 s expansion of the coal industry had an important effect on the amount of poverty found in the Central Appalachian region. $^{19}$

What did the economic improvement of the 1970s really mean? Primarily, the expansion of the coal industry in the 1970s meant not only that the percentage of people in poverty decreased during the decade, it also meant that there were fewer children forced to grow up in poverty. Regionwide, the percentage of families in poverty dropped from 14.9 percent in 1970 to 11.0 percent in 1980. Central Appalachia enjoyed a decline in childhood poverty as well. In 1980, the Central Appalachian region had a family poverty rate of 19.2 percent, up from the 1970 rate of 30.2 percent. The family rates of poverty do not fully explain the number of children living in poverty since families have different numbers of children. Of course, high rates of poverty for families usually mean that a high percentage of children live in poverty. Conversely, an improvement in the poverty rate for families also means that fewer children will face the prospects of impoverishment. As a result of the improved economic conditions of the 1970s, the child poverty rate in Appalachia improved from 18.9 percent to 17.0 percent during the decade. As with every other indicator of poverty, Central Appalachia had a higher rate of poverty than the other subregions of Appalachia. However, even Central Appalachian children saw an improvement in their

\footnotetext{
${ }^{19}$ Couto, An American Challenge, 143-144.
} 
economic situation. In 1970, the poverty rate of children living in the Central Appalachian subregion was 35.0 percent. In 198025.7 percent of the children of the subregion lived in poverty. The improvement in childhood poverty rates in Appalachia stand in stark contrast to those of the rest of the nation. As deindustrialization spread throughout the country, along with other economic problems of the turbulent 1970s, more children nationwide fell under the poverty line. Nationally, the rate of children in poverty rose from 14.9 percent in 1970 to 16.0 percent in 1980 . Therefore, while the situation for Appalachian children continued to improve during the 1970s, nationally the economic climate was unhealthy, foreshadowing the problems Appalachia would face in the $1980 \mathrm{~s}^{20}$

There was another significant result of the improved economic conditions of the 1970s. Because the demand for coal increased as a result of the energy crisis of the 1970s, job prospects improved significantly. Many Appalachian migrants who left the region during the 1950s and 1960s were now able to return. Donald Bowles was one such example. After moving to Michigan in the mid-1960s to work in the construction industry, homesickness eventually began to set in for the Bowles family. When an opportunity arose to return to McDowell County and work in the mines in 1975, Bowles decided to move. When asked why he came back, Bowles had a simple answer, "This is home." ${ }^{, 21}$ After working in several mines in the Kimball and Keystone

\footnotetext{
${ }^{20}$ Ibid., $155-166$.

${ }^{21}$ Donald Bowles, Interview by the author, 5 September 2005, Welch, WV, Tape Recording, in author's personal collection.
} 
areas, Bowles eventually went to work for U.S. Steel in Pineville, Wyoming County, from which he retired in $1997 .^{22}$

The late 1970s ushered in a new, yet familiar period in Appalachian economic history. Nationally, the American economy began a period of recession during the latter part of the decade. Appalachia suffered from the same problems as the rest of the country. One of the primary reasons for the downturn in the national economy was the shift of the economy from a manufacturing to a service-based economy. Furthermore, government cutbacks during the Reagan administration damaged the social safety net created by the War on Poverty. Deindustrialization was in full swing and the entire nation was feeling the effects of the problem. In February 1982, at the height of the recession, the regional unemployment rate stood at 12.4 percent in Appalachia. Budget cuts in social programs, including the ARC, disproportionately harmed the Appalachian economy. One reason for this problem was the fact that much of the money earmarked for social programs was transferred to military spending. Because there are few military installations in Appalachia and the importance of government programs for the people of the region, the transference of money from social programs to the military had an adverse effect on the region. ${ }^{23}$

As impressive as the gains were in Central Appalachia during the 1970s, the 1980s represented a significant decline in the economic indicators of the region. In the

\footnotetext{
${ }^{22}$ Ibid.

${ }^{23}$ Haynes, Poverty in Central Appalachia, 95-96. See also: Barry Bluestone and Bennett Harrison, The Deindustrialization of America: Plant Closings, Community Abandonment, and the Dismantling of Basic Industry (New York: Basic Books, 1982) and W.J. Nagle, "Appalachia Fights for Jobs in a Recession," Appalachia 15, 5 (1982): 1-9.
} 
1980s, McDowell County had a decline of 19.6 percent in the ratio of county per capita income to the national rate. The 1989 ratio of county income to the national rate was 49.3 percent. The per capita income of the entire Central Appalachian region fell by 5 percent during the decade as well. The primary reason for this problem was the very nature of the coal industry. Although the 1970s was a decade of great expansion in the coal industry due to the energy crisis, the 1980s proved that the expansion was shortlived and that the industry had fallen back into the traditional boom and bust cycle. The 1980s happened to be a period of bust for the industry. The period between 1982 and 1984 was the worst period for mine closures, including for many of the mines discussed before in this study. The Olga operations shut down and reopened a few times during this period before being permanently closed. ${ }^{24}$ U.S. Steel miners in the Gary district were not immune to the job cuts. A 1984 Welch Daily News headline declared "1,500 U.S. Steel Workers Idled." ${ }^{25}$ The company that was for many years the largest single employer in the county would leave McDowell for good by the late 1980s.

The problems of the 1980s implemented a new dynamic into the discussion of the current state of the Central Appalachian region. The economic problems of the decade created a new class of poor, those who suffered from the economic restructuring in the region as coal companies further deindustrialized and left the region, this time for good. The problems of this class, along with the problems of those who could not make it out of the poverty of the 1960 s, created a society in which people had very

\footnotetext{
${ }^{24}$ Welch Daily News, 4 October 1982; Dennis Myers, interview by the author, 17 April 2008, Muncie, Indiana, tape recording, in the author's personal collection.

${ }^{25}$ Welch Daily News, 27 September 1984.
} 
little. The poverty that struck the county, and the region as a whole, forced folks to make the best of a difficult situation and, in many ways, they have succeeded. ${ }^{26}$

The Central Appalachian region saw a decline in the other predominant economic indicators during the 1980s as well. The increased poverty indicative of the 1980s brought poverty levels similar to the period before 1970 in some areas of the region, particularly the coal producing counties of southern West Virginia. In Central Appalachia as a whole, the gains made during the 1970s leading to the decline of people living in poverty were reversed by the subsequent decline in the coal industry. As stated above, the poverty rate in 1980 stood at 22.3 percent in Central Appalachia. By 1990 , however, the rate had increased to 25.3 percent. In sum, fully one-quarter of the people living in Central Appalachia in 1990 lived in poverty. Therefore, although there were slight improvements in the poverty rate after 1970, poverty remained an epidemic throughout the region. ${ }^{27}$

The decline in family income that characterized Central Appalachia during the 1980s represents the real effect poverty had on the people of the region. The median family income in Central Appalachia as a percentage of the national median family income fell during the decade from 70.6 percent to 61.1 percent. The median family income in McDowell County as a percentage of the national rate is even lower than the region as a whole. McDowell County's percentage of national median family income was below 50 percent in 1990, a rate comparable to the poorest counties of the region.

\footnotetext{
${ }^{26}$ Couto, An American Challenge, 87-88.

${ }^{27}$ Ibid., 143-146.
} 
What does this decline in median family income truly mean? Simply stated, the decline in family income resulted in an increase in the number of families in poverty. The family poverty rate in Central Appalachia increased from 19.2 percent in 1980 to 22.2 percent in 1990. The rates of families in poverty in Central Appalachia in 1990 were more than double the national rate, which stood at about 10 percent during that year. Logically, if more and more families were faced with poverty during the 1980s, childhood poverty should increase as well. This is the exact pattern faced by Appalachians during the late 1980s. The poverty rate for children in Central Appalachia increased from 25.7 percent in 1980 to 30.1 percent in 1990. As with the median family income indicator, McDowell County had a childhood poverty rate that was even higher than the region as a whole. In McDowell, the poverty rate for children was more than 40 percent. ${ }^{28}$

Statistics can only tell so much of the story. How did the economic climate of the 1980s affect the inhabitants of Appalachia? How did the people of the region cope and react to the declining opportunities indicative of the era? It is extremely important to discuss the experiences of the people in order to put a human face on the story of McDowell County, and the rest of Central Appalachia, during this trying time in its history. One important story was described by Mike Yarrow in his selection "Voices from the Coalfields," from the edited work titled Communities in Economic Crisis. Yarrow spoke to 90 people affected by the decline in the coal industry in southern West Virginia and southwestern Virginia in 1986 and 1987. With the restructuring occurring in the coal industry during the 1980s, the biggest fear for working miners was losing

${ }^{28}$ Ibid., 143-166. 
their jobs. As a result of this fear, miners agreed to work long hours, usually six days each week. As one miner put it:

During the last year before any mine blows out they usually try to get all the coal they can. So I was working six days a week, sometimes 10 and 12 hours a day. And I made about $\$ 35,000$. It sounds like a lot but it's a lot of Saturdays. I was able to save a little bit of money. ${ }^{29}$

But for many miners, their greatest fears were realized as mines began to shut down during the 1980s. As the miner above continued:

But I didn't think I'd be laid off, because I was working for a mine owned by a railroad. I knew they weren't making a lot of money on the coal, but I thought they was making their money on the haulage. But they shut her down. It's been flooded and it's not going back. It shocked me. I took all my savings and paid off every bill I had, Master Charge, car, and put away $\$ 2,000$. We planned to get through to the end of August. ${ }^{30}$

With the lack of diversification in the economy of the region, laid off miners had few options for employment. The employment that was available primarily consisted of low-wage service jobs in the restaurant or retail business. Even low-wage service jobs were preferable to the possibility of losing everything and depending on the government, friends, and neighbors. As our unnamed miner said:

I thought by that time [August] I would really find a job. I have been to 7-Eleven stores. I have been to every hotel applying for a night auditor job. And everything conceivable I applied for. I ended up mowing grass. When you don't have nothing, $\$ 10$ is a lot of money. ${ }^{31}$

\footnotetext{
${ }^{29}$ Mike Yarrow, "Voices from the Coalfields: How Miners' Families Understand the Crisis of Coal," in John Gaventa, Barbara Ellen Smith, and Alex Willingham, eds., Communities in Economic Crisis: Appalachia and the South (Philadelphia: Temple University Press, 1990), 43.

${ }^{30}$ Ibid.

${ }^{31}$ Ibid.
} 
Also, as time passed with the workers of the region depending on unemployment benefits from the government, difficult decisions had to be made. Everything from large decisions such as car maintenance to small issues such as providing non-essential items for the children, such as a small toy or a treat, took on much larger meanings. For some, this state of affairs lasted only a short amount of time.

I was off for nine months one time and unemployment run out. You had to weigh the decision to buy a popsicle for your child. I was going to graduate school and I came home to find out I had been called back to work and had to quit school. I was so happy - the feeling of going back....I remember getting the first paycheck and going to the store and buying food and coming home and crying. Crying because I was happy I could buy food. But at the same time all the other people at the store were on food stamps. Because West Virginia has been going down for a long time. I was watching how they weighed their decisions to buy this or that with their food stamps, decisions I was making just a week before. And I filled my cart up with steaks, with soda pop for the mines. ${ }^{32}$

Others were not as fortunate as the lucky ones who were called back to work.

For many, unemployment and government assistance became a permanent reality. As

the problems became more evident in the psyche of the people of the region, social

problems sometimes developed in the families and communities affected by the

downturn in the coal industry. As a miner's wife stated:

What is so bad around here is that men only know coalmines. I bet our divorce rate has gone up fifty percent since our mines have shut down in the past three years. When times get hard, some don't pull together. Wives, husbands have left. The security goes. Some women look at their husbands as a meal ticket. People panic, put too much value on money.

You see depression, you see aggravation, you see alcoholism, you see drug abuse, you see battered wives, you see mistreated children, you see abandoned children. I'm talking about the whole country. You see suicide.

${ }^{32}$ Ibid., 43-44. 
You see some of the women having to get work, and the men staying home and having to take care of the kids. They resent that. ${ }^{33}$

Although the economic problems facing the region did change the communities of the coalfields, residents adapted extremely well to the changing economic situation. There continued to be strong support networks among family and friends, even if it was not the same as it had been before. Families learned to cut expenses, take on odd jobs, and support one another. As one young father described:

Your in-laws will help you, or your parents. If you don't want them to give it to you, you go up there and do a job for them, paint their house, help them with carpentry work. You work it out so you are not accepting charity. I painted one house that is like forty feet high. The yard is straight down toward the riverbank. I got paid darn good. I painted it once before during the strike in 1978. I told my wife then, "Never would I paint that house again." Well, there I was. $^{34}$

There were other folks besides miners who suffered as a result of the decline of available employment in the coal industry. Even people who were not directly affected by the deindustrialization of McDowell felt the impact of the lack of jobs in the county. For some people, the impact was aesthetic. Angeline Harmon, in discussing the changes taking place in the county, noted: “There's so much filth. Didn't used to be like that. This used to be the prettiest community right here....Everybody was clean; their children was clean. You could let your children go visit neighbors. Now I wouldn't let my grandchildren out of this yard under no circumstances.... You saw what a mess you had to come through to get here."35 Although an aesthetic quality does not

\footnotetext{
${ }^{33}$ Ibid., 44.

${ }^{34}$ Ibid., 45.

${ }^{35}$ Angeline Harmon, interviewed by H. Renee Viers, 2 July 1992, tape recording and transcript, Eastern Regional Coal Archives, Craft Library, Bluefield, WV.
} 
impact the economic livelihood of people, a perception of disarray and filthiness can lead to a decline in the quality of life of a people.

There was also a significant change in available services in McDowell County. The decline of such disparate services as retail stores, funding for infrastructure, and financing for education all contributed to a decline in the feeling of community so prevalent in the McDowell County of yesteryear. Many people noted the significant contrast between the county of their youth and the county of the present. In discussing the quality of life in the coal camps, McDowell resident Lola Dunigan describes the changes that took place in the region. In talking about what people did for fun in her youth, she stated: "Yeah go down to War and shop around. When you go to War, gets so crowded on payday or maybe all the time because I just only went on payday, and you couldn't hardly get through town. They was stores differ[ent]....You don't see things like that now. You really don't, and you just couldn't hardly get through town for the life of you; there was so many people. Just like New York City....It's altogether a different town." ${ }^{, 36}$ She goes on to say: "It looks like a ghost town from what it used to be....It used to be everything you'd want. ${ }^{37}$ Because of a decline of available retail stores in all the communities of McDowell County, residents were soon required to travel to distant cities such as Bluefield or Beckley to purchase needed items. Without the opportunity to shop local stores, residents lost much of the loyalty they had previously felt toward their community.

\footnotetext{
${ }^{36}$ Lola Dunigan, interviewed by H. Renee Viers, 17 June 1992, tape recording and transcript, Eastern Regional Coal Archives, Craft Library, Bluefield, WV.

${ }^{37}$ Ibid.
} 
Of course, aesthetic concerns and the loss of opportunity to support local business were not the only problems resulting from the deindustrialization of McDowell County. With the loss of business in the last quarter of the twentieth century, the county suffered a significant decline in tax revenue. A decline in tax revenue led to a corresponding decline in funding for schools of the county, as noted by Ira Short, a former assistant superintendent of McDowell County schools.:

As your population declined, you had to watch. Some teachers had to be discharged, but in the main, usually retirement took care of most of that. I don't recall that we ever had any teachers that we really could not place somewhere. They might not be right where they wanted but they couldn't. The population decline affects everything. When your population declines, your taxes go down, and your schools, the population in the school goes down. At times, you have to rearrange your schedule.... ${ }^{38}$

Opportunities declined for the children of McDowell County as well because of the tax shortfall. With a decline in funding and a decrease in the school population, many programs had to be cut. Although Short, when interviewed in 1992, downplayed the problem, any cut in services potentially could mean the difference between success and failure for children. To improve the economy of any disadvantaged region, an improvement in infrastructure, both physical and human, is required. Because human infrastructure primarily includes education and job training, a decline in school funding hinders the economic development of the region. Although the decline in school funding seriously harmed specific groups living in McDowell County, how did the impact on deindustrialization on schools result in the decline of community? For many people, the schools represented the focal point of the community. With the closing of

\footnotetext{
${ }^{38}$ Ira Short, interviewed by H. Renee Viers, 2 July 1992, tape recording and transcript, Eastern Regional Coal Archives, Craft Library Bluefield, WV.
} 
many of the schools due to a decline in funding, communities lost one of the ties that bound residents together. ${ }^{39}$

For most members of the McDowell County community, the deindustrialization of the county caused great sadness. Many remembered with great nostalgia the county of their youth and wished things could have been like they were before. The sense of community many of these folks felt was immeasurable. There were some people, originally from McDowell, who felt differently, however. For Gene Webster, realism overcame any desire for the McDowell community of yesteryear. Webster was born in 1927, and many other people who grew up in the same era discuss how wonderful growing up in McDowell County was during the coal boom. Webster's sentiment was more mixed. When asked if he had any final thoughts about growing up in the southern West Virginia coalfields, Webster stated: "No, if you can do better, better to never stay in coalfields....You go to work in the mines, you get hurt or something, and a lot of people's on Black Lung for working in the mines. That's why they went in the mines. To me, it was very dangerous, but right now the coal fields are more or less gone."40 Webster's response is a rare one for people of his generation. Most did not suggest leaving the county; rather they usually talked about the changes occurring with great sadness. Webster's matter-of-fact response shows that he has a keen insight and interest in the problems facing the county. His response was mixed, however, because

\footnotetext{
${ }^{39}$ This issue of loss of community from school closure affected many people in the county. For example, many graduates of the former Gary High School (which closed in 1978) meet on the first weekend of August every year for a reunion. For the affect school closures had on the African American community, see: Alice E. Carter, "Segregation and Integration in the Appalachian Coalfields: McDowell County Responds to the Brown Decision," West Virginia History 54 (1995): 78-104.

${ }^{40}$ Gene Webster, interviewed by H. Renee Viers, 18 June 1992, tape recording and transcript, Eastern Regional Coal Archives, Craft Library, Bluefield, WV.
} 
he does display a bit of nostalgia in discussing how nice the local cities were during the heyday of the coal industry. Yet, he concludes his statement by analyzing what would need to happen for the coal industry to improve once again. "But, I don't know if they'll ever come back. I don't think they'll ever come back unless the oil runs out., ${ }^{, 41}$

One other example of a decline in community spirit among people of the county can be seen in discussions of the causes of the economic catastrophe that faced McDowell County in the latter decades of the twentieth century. Some blamed the people of the county for being too dependent on government assistance for their survival. Some blamed the government, while others blamed the union for the decline of available jobs in the coal industry. Very few people, in the small sample available, blamed the companies or the economic system for the problems facing the county. By blaming the people who depend on government assistance for help, citizens of the county show a lack of the community spirit, the willingness to help those in need, that so characterized the McDowell County of the industrial period. Of course, there are examples of people who, as Angeline Harmon put it, "have gotten too durn sorry to take care of themselves. ${ }^{, 42}$ The problem is that many people dependent on welfare benefits for survival would actually work if given the opportunity, yet are often grouped into the same class as those who do not want to work.

After 1960 McDowell County faced an economic crisis of immeasurable proportion. Because of the county's overdependence on the coal industry, the decline of coal employment resulting from the deindustrialization of the county put a

\footnotetext{
${ }^{41}$ Ibid.

${ }^{42}$ Harmon interview.
} 
significant crunch on employment options for the county's residents. For the residents who decided not to migrate to areas where job opportunities were better, times became difficult as many lost their jobs as the industry reorganized itself. From 1960 to 1990 the economic climate of McDowell County fluctuated as the industry continued through the boom-and-bust cycles indicative of the coal industry. Despite the improvement of the coal industry as a result of the energy crisis of the 1970 s, poverty remained a serious problem in the entire Central Appalachian region, of which McDowell County is a part. Throughout the entire region, up to 25 percent of the population remained mired in poverty by 1990 , creating a serious social problem to be dealt with by social scientists. Why has the region continued to suffer from endemic poverty? Theorists in the past have suggested that there is an inherent cultural flaw in Appalachian society that results in an endless cycle of poverty. As time passed, it became clear that these so-called cultural flaws, particularly the so-called fatalism of the Appalachian psyche, have been over-generalized as a standard aspect of Appalachian society. Theorists of the 1970s looked to a different explanation for poverty in Appalachia. To the proponents of the internal colony theory, outside interests who owned Appalachia from the industrial period have taken the region's natural resource wealth without reinvesting the money into the local economy. Because of the lack of money going to the local people, poverty developed as the industrial system matured during the mid-twentieth century. I argue that both predominant theories of Appalachian poverty have serious flaws. First, the culture of poverty theory over-simplifies the problem and places a cultural explanation on what is essentially an economic problem. The internal colony theory, while placing an appropriate emphasis on the economic nature of the problem, 
does not place enough of an emphasis on the role of local leaders in the economic development of the region. Although absentee owners did, and continue to, own much of the available land throughout the Central Appalachian region. Local leaders did not do enough to try to diversify the economy of the region. Without economic diversification, the people of the county were unable to find alternate work at home once many of the coal-related jobs disappeared.

Structural reasons for poverty are not the entire story, however. Although many of the traditional community relationships declined as people moved from the region and those who stayed slipped into poverty, relationships between people continued to thrive in a different way. As the people of the region suffered with the loss of their jobs, family members and, in some cases, friends came together to ensure the survival of their families. In many instances, people moved in together and shared resources to get through the hard times. There are also stories of success as many people who were called back to the mines during the 1970s succeeded in making a career for themselves. Miners are not the only members of the community as well. As the economy changed from one dependent on industry, the service sector became more important to the overall economic health of the region. As a result, there are numerous stories of success in the middle class of the county. Therefore, despite the overwhelming poverty that many studies focus on when discussing the economic condition of the region, there have been stories of success. Generalizations are extremely difficult and do not fully explain the story of McDowell County in the post-war period. 


\section{Conclusion}

The history of the Central Appalachian region has been primarily characterized by the socio-economic impact of extractive industries, predominantly coal. Because of the rural nature of the region prior to the introduction of the coal industry, the construction of coal towns, importation of outside labor, and the generally exploitive nature of the coal industry resulted in the development of a unique coalfield community based on common experiences in the coal-based economy. Historians have studied this period in detail, but have only recently turned their attention to another pressing historical issue, the impact of deindustrialization, as characterized by mechanization and consolidation of the coal industry, on the region. McDowell County is an important microcosm of the problems resulting from this phenomenon throughout the region because of the relative importance of the county in the nation's coal production for many years and the profound significance the industry had on the county's economy. The contraction of available jobs in the coal industry led to a drastic decline in population, a drop in tax revenues, and an increase in poverty that has come to characterize the entire Appalachian region in the American consciousness.

The evidence of a decline in the community that characterized McDowell County for so many years is multifaceted. The primary evidence lies in the fact that thousands of people from McDowell realized the need to leave the region in order to find work and to provide a quality of life unattainable in West Virginia. Community connections often fell apart with distance. For the people who remained in the county, a mixed record of success and poverty became the norm. Rather than coming together based on common experiences, people living in the county tended to drift apart. Neighbors hardly knew one 
another. Towns lost the schools that played such an important role in their communities as consolidation occurred after the mid-1960s. People began to look at others who were less fortunate with great disdain; community pride was at a nadir. The county just did not mean what it once did to the people who lived there as can be seen in the nostalgia for yesteryear described by so many.

Although the community that characterized the county for so many years is irretrievably gone, it is still possible that a socio-economic improvement could characterize the McDowell County of the early twenty-first century. New economic opportunities, particularly in the field of corrections, the plan for two four-lane highways to foster development, and continued improvement in the school system provide hope for those who for many years had little to look forward to. This story is also important because of what it tells scholars about the nature of Appalachian industrialization. Although in many ways Appalachia was an internal colony control by outside capitalistic forces, local political and business elites also played a role in the eventual impoverishment of the region. In the example of McDowell County, no business, political, or labor leader made an effort to diversify the economy of the region in order to provide options for the people of the county. In many instances, this was not in the best interest of the leadership, particularly business leaders. However, the failure of the union to provide opportunities for the displaced miners stands as a tragic example in the history of labor, Appalachia, and the nation. 


\section{Bibliography}

\section{Manuscript Collections}

Collins, Justin Papers. West Virginia Regional History Collection. West Virginia University, Morgantown.

Fleming, A.B. Papers. West Virginia Regional History Collection. West Virginia University, Morgantown.

Pocahontas Operators Association Papers, 1941-1973. West Virginia Regional History Collection. West Virginia University, Morgantown.

Records of the National Recovery Administration. Record Group 9. National Archives, College Park, MD.

United Pocahontas Coal Company Archives. West Virginia Regional History Collection. West Virginia University, Morgantown.

\section{Interviews}

Bowles, Donald. Interview by author, 5 September 2005, Welch, WV. Tape recording. In author's personal collection.

Cabiness, Irma. Interview by Peggy Turnbill. Transcript. Bluefield State College Archives, Bluefield, WV.

Dunigan, Lola. Interview by H. Renee Viers, 17 June 1992. Tape recording and transcript. Eastern Regional Coal Archives, Bluefield, WV.

Fuller, Garnet. Interview by H. Renee Viers, 26 June 1992. Tape recording and transcript. Eastern Regional Coal Archives, Bluefield, WV.

Goodman, Helen. Interview by H. Renee Viers, 1 July 1992. Tape recording and transcript. Eastern Regional Coal Archives, Bluefield, WV.

Harmon, Angeline. Interview by H. Renee Viers, 2 July 1992. Tape recording and transcript. Eastern Regional Coal Archives, Bluefield, WV.

Haynes, Paul. Interview by H. Renee Viers, 18 June 1992. Tape recording and transcript. Eastern Regional Coal Archives, Bluefield, WV.

Hendricks, Floyd. Interview by author, 8 March 2001, Vivian, WV. Tape recording. In author's personal collection. 
Hendricks, James. Interview by author, 24 November 2001, Vivian, WV. Tape recording. In author's personal collection.

Myers, Dennis. Interview by author, 17 April 2008, Muncie, IN. Tape recording. In author's personal collection.

Rose, Elmer. Interview by H. Renee Viers, 10 June 1996. Tape recording and transcript. Eastern Regional Coal Archives, Bluefield, WV.

Ruff, Richard. Interview by H. Renee Viers, 22 June 1992. Tape recording and transcript. Eastern Regional Coal Archives, Bluefield, WV.

Short, Ira. Interview by H. Renee Viers, 2 July 1992. Tape recording and transcript. Eastern Regional Coal Archives, Bluefield, WV.

Signaigo, Leo. Interview by H. Renee Viers, 30 June 1992. Tape recording and transcript. Eastern Regional Coal Archives, Bluefield, WV.

Webb, Helen. Interview by H. Renee Viers., 18 June 1992. Tape recording and transcript. Eastern Regional Coal Archives, Bluefield, WV.

Webster, Gene. Interview by H. Renee Viers, 18 June 1992. Tape recording and transcript. Eastern Regional Coal Archives, Bluefield, WV.

\section{Published National and State Records}

Appalachian Regional Commission. Population and Net Migration Trends in the Appalachian Region. Washington: Appalachian Regional Commission, 1971.

. "The Demand for Energy and Appalachia's

Coal." Appalachia 5, 4 (1972): 1-5.

. A Report to Congress on Migration. Washington: Appalachian Regional Commission, 1979.

. “Appalachia: Twenty Years of Progress.” Appalachia 19, 2-4 (1986): 8-15.

Boone, Joel T. A Medical Survey of the Bituminous Coal Industry. Washington: U.S. Department of the Interior, 1947.

Hotchkiss, Willard E., F.G.Tryon, Charlotte K. Warner, et.al. Mechanization, Employment, and Output per Man in Bituminous Coal Mining. Philadelphia: Works Progress Administration, 1939. 
Jacobson, Louis S. "Earnings Losses of Workers Displaced from Manufacturing Industries." In U.S. Department of Labor, The Impact of International Trade and Investment on Employment. William G. Dewald, ed. Washington: U.S. Government Printing Office, 1978.

National Advisory Committee on Rural Poverty. The People Left Behind. Washington: U.S. Government Printing Office, 1967.

State of West Virginia. Annual Report of the Department of Mines. Charleston, 1926.

. Annual Report of the Department of Mines. Charleston, 1927.

. Annual Report of the Department of Mines. Charleston, 1928.

. Annual Report of the Department of Mines. Charleston, 1929.

. Annual Report of the Department of Mines. Charleston, 1931.

. Annual Report of the Department of Mines. Charleston, 1932.

. Annual Report of the Department of Mines. Charleston, 1933.

. Annual Report of the Department of Mines. Charleston, 1934.

. Annual Report of the Department of Mines. Charleston, 1936.

. Annual Report of the Department of Mines. Charleston, 1937.

. Annual Report of the Department of Mines. Charleston, 1938.

. Annual Report of the Department of Mines. Charleston, 1940.

. Annual Report of the Department of Mines. Charleston, 1945.

. Annual Report of the Department of Mines. Charleston, 1950.

. Annual Report of the Department of Mines. Charleston, 1955.

. Annual Report of the Department of Mines. Charleston, 1960.

. Annual Report of the Department of Mines. Charleston, 1970. 
Thompson, James Howard. The Condition and Prospects of the West Virginia Economy: Submitted to Governor W.W. Barron, December 6, 1963. Charleston: The Governor's Council of Economic Advisors, 1963.

U.S. Department of Commerce. Historical Statistics of the United States, Colonial Times to 1970, part 1.

U.S. Department of Commerce, Bureau of the Census. United States Census of Population, 1950. General Characteristics. West Virginia: General Data on Age, Sex, Race, Marital Status, Education, Employment, Income, Occupation, Industry, Etc. Washington: U.S. Government Printing Office, 1952.

. 1950 Census of the Population, Volume 1, Number of Inhabitants.

Washington: U.S. Government Printing Office, 1952.

. Census of the Population, 1960. Volume 1. Characteristics of the

Population: Number of Inhabitants, general population characteristics, general social and economic characteristics, and detailed characteristics. Part 50. West Virginia. Washington: U.S. Government Printing Office, 1962.

U.S. Department of Commerce, Social and Economic Statistics Administration, Bureau of the Census. 1970 Census of Population. Volume 1, Characteristics of the Population. Part 50, West Virginia. Washington: U.S. Government Printing Office, 1972.

United States Congress Office of Technology Assessment. An Assessment of Development of Production Potential of Federal Coal Leases. Washington: United States Congress Office of Technology Assessment, 1981.

West Virginia Bureau of Negro Welfare and Statistics. Negro Housing Survey of Charleston, Keystone, Kimball, Wheeling, and Williamson. Charleston: Jarrett Printing Company, 1938.

West Virginia Commissioner of Labor. $21^{\text {st }}$ Biennial Report of the Department of Labor. Charleston, 1933.

\section{Newspapers and Periodicals}

Baltimore Evening Sun

Bluefield (WV) Daily Telegraph

Charleston (WV) Gazette

Charleston (WV) Sunday Gazette Mail

Coal Age

Coal Industry

Coal Mine Management 


\section{Fortune}

McDowell Times

Mining Congress Journal

National Coal Association Bulletin

National Coal Industry Bulletin

New York Times

Outlook

United Mine Workers Journal

U.S. News and World Report

Wall Street Journal

Welch (WV) Daily News

Wheeling Intelligencer

\section{Books}

Akin, William E. West Virginia Baseball: A History, 1865-2000. Jefferson, NC: McFarland and Company, 2006.

Ambler, Charles H. and Festus P. Summers. West Virginia: The Mountain State. Englewood Cliffs, NJ: Prentice-Hall, 1958.

Appalachian Land Ownership Task Force. Who Owns Appalachia? Landownership and Its Impact. Lexington: University Press of Kentucky, 1983.

Axelrod, Jim, ed. Growing Up Country. Clintwood, VA: Council of the Southern Mountains, 1973.

Baratz, Morton. The Union and the Coal Industry. New Haven, CT: Yale University Press, 1955. Reprint, New York: Kennikat Press, 1973.

Barger, Harold and Sam H. Schurr. The Mining Industries, 1899-1939: A Study of Output, Employment, and Productivity. New York: National Bureau of Economic Research, 1944. Reprint, New York: Arno Press, 1972.

Batteau, Allen W. The Invention of Appalachia. Tucson: University of Arizona Press, 1990.

Battlo, Jean. McDowell County in West Virginia and American History. Parsons, WV: McClain Printing Company, 1998.

Bell, Daniel. The Coming of Post-Industrial Society: A Venture in Social Forecasting. New York: Basic Books, 1973.

Berkowitz, N. An Introduction to Coal Technology. New York: Academic Press, 1979. 
Bernstein, Irving. Turbulent Years: A History of the American Worker, 19331941. Boston: Houghton Mifflin, 1970.

Berry, Chad. Southern Migrants, Northern Exiles. Urbana: University of Illinois Press, 2000.

Bethell, Thomas N. Conspiracy in Coal. Huntington, WV: Appalachian Movement Press, 1971.

Bickley, Ancella R. and Lynda Ann Ewen, ed. Memphis Tennessee Garrison:

The Remarkable Story of a Black Appalachian Woman. Athens: Ohio University Press, 2001.

Billings, Dwight B. and Kathleen B. Blee. The Road to Poverty: The Making of Wealth and Hardship in Appalachia. Cambridge, UK: Cambridge University Press, 2000.

Billings, Dwight B., Gurney Norman, and Katherine Ledford, ed. Back Talk from Appalachia: Confronting Stereotypes. Lexington: University Press of Kentucky, 1999.

Birch, David L. The Job Generation Process. Cambridge, MA: MIT Program on Neighborhood and Regional Change, 1979.

Black, Edie and Fred Goff. The Hanna Industrial Complex. New York: North American Congress on Latin America, 1969.

Bluestone, Barry and Bennett Harrison. The Deindustrialization of America: Plant Closings, Community Abandonment, and the Dismantling of Basic Industry. New York: Basic Books, 1982.

Bodnar, John. The Transplanted: A History of Immigrants in Urban America. Bloomington: Indiana University Press, 1985.

Borman, Kethryn M. and Phillip J. Obermiller, ed. From Mountain to Metropolis: Appalachian Migrants in American Cities. Westport, CT: Bergin and Garvey, 1994.

Brecher, Jeremy. Strike! San Francisco: Straight Arrow Books, 1972.

Brophy, John. A Miner's Life. Madison: University of Wisconsin Press, 1964.

Brown, John W. Constitutional Government Overthrown in West Virginia. Wheeling, WV: Majority Company, 1913. 
Callcott, George H. Maryland and America: 1940 to 1980. Baltimore: Johns Hopkins University Press, 1985.

Carawan, Guy and Candie Carawan. Voices from the Mountains. New York: Alfred A. Knopf, 1975.

Caudill, Harry M. My Land is Dying. New York: Dutton, 1971. - Night Comes to the Cumberlands: A Biography of a Depressed Area. Boston: Little, Brown, and Company, 1963.

Chafin, Raymond and Topper Sherwood. Just Good Politics: The Life of Raymond Chafin, Appalachian Boss. Pittsburgh: University of Pittsburgh Press, 1994.

Christenson, Carroll L. Economic Redevelopment in Bituminous Coal: The Special Case of Technological Advance in United States Coal Mines, 1930-1960. Cambridge, MA: Harvard University Press, 1962.

Coles, Robert. The South Goes North. Boston: Little, Brown, 1971.

Commission on Religion in Appalachia. Economic Transformation: The Appalachian Challenge. Knoxville, TN: Commission on Religion in Appalachia, 1986.

Conley, Phil. History of the West Virginia Coal Industry. Charleston, WV: Education Foundation, 1960.

Corbin, David Alan. Life, Work, and Rebellion in the Coal Fields: The Southern West Virginia Miners, 1880-1922. Urbana: University of Illinois Press, 1981.

Couto, Richard A. An American Challenge: A Report on Economic Trends and Social Issues in Appalachia. Dubuque, IA: Kendall Hunt, 1994.

. Poverty, Politics, and Health Care: An Appalachian Experience.

New York: Praeger, 1975.

Cowie, Jefferson. Capital Moves: RCA's Seventy-Year Quest for Cheap Labor. Ithaca, NY: Cornell University Press, 1999.

Cunningham, Rodger. Apples on the Flood: The Southern Mountain Experience. Knoxville: University of Tennessee Press, 1987. 
Derickson, Alan. Black Lung: Anatomy of a Public Health Disaster. Ithaca, NY: Cornell University Press, 1998.

Dix, Keith. What's a Coal Miner to do? The Mechanization of Coal Mining. Pittsburgh: University of Pittsburgh Press, 1988.

. Work Relations in the Coal Industry: The Hand-Loading Era, 18801930. Morgantown: West Virginia University, 1977.

Dubofsky, Melvyn and Warren Van Tyne. John L. Lewis: A Biography. New York: Quadrangle, 1977.

Eller, Ronald. Miners, Millhands, and Mountaineers: Industrialization of the Appalachian South. Knoxville: University of Tennessee Press, 1982.

Ergood, Bruce and Bruce Kuhre, ed. Appalachia: Social Context Past and Present. Dubuque, IA: Kendall Hunt, 1976.

Feather, Carl E. Mountain People in a Flat Land: A Popular History of Appalachian Migration to Northeast Ohio, 1940-1965. Athens: Ohio University Press, 1998.

Fink, Gary M., ed. Labor Unions. Westport, CT: Greenwood Press, 1977.

Fisher, Stephen L., ed. Fighting Back in Appalachia: Traditions of Resistance and Change. Philadelphia: Temple University Press, 1993.

Fleming, Daniel B. Kennedy vs. Humphrey, West Virginia, 1960: The Pivotal Battle for the Democratic Presidential Nomination. Jefferson, NC: McFarland, 1992.

Fones-Wolf, Ken and Ronald L. Lewis, ed. Transnational West Virginia: Ethnic Communities and Economic Change, 1840-1940. Morgantown: West Virginia University Press, 2002.

Ford, Thomas R., ed. The Southern Appalachian Region: A Survey. Lexington: University of Kentucky Press, 1962.

Fox, Maier B. United We Stand: The United Mine Workers of America, 18901990. Washington: UMWA, 1990.

Galambos, Louis. Competition and Cooperation: The Emergence of a National Trade Association. Baltimore: Johns Hopkins Press, 1966. 
Gaventa, John. Power and Powerlessness: Quiescence and Rebellion in an Appalachian Valley. Urbana: University of Illinois Press, 1980.

Gaventa, John, Barbara Ellen Smith, and Alex Willingham, ed. Communities in Economic Crisis: Appalachia and the South. Philadelphia: Temple University Press, 1990.

Gazaway, Rena. The Longest Mile: A Vivid Chronicle of Life in an Appalachian Hollow. Baltimore: Penguin, 1969.

Goodrich, Carter. The Miner's Freedom: A Study of the Working Life in a Changing Industry. Boston: Marshall Jones Company, 1925.

Gregory, James N. The Southern Diaspora: How the Great Migrations of Black and White Southerners Transformed America. Chapel Hill: University of North Carolina Press, 2005.

Harris, Evelyn and Frank Krebs. From Humble Beginnings: West Virginia State Federation of Labor, 1903-1957. Charleston: West Virginia Labor History Publishing Fund, 1960.

Harvey, Curtis E. Coal in Appalachia: An Economic Analysis. Lexington: University Press of Kentucky, 1986.

Hatcher, Thomas C., Geneva Steele, Sandra Long, and Christine Carr McGuire, eds. The Heritage of McDowell County, West Virginia 1858-1995. War, WV: McDowell County Historical Society, 1995.

Hattam, Victoria C. Labor Visions and State Power: The Origins of Business Unionism in the United States. Princeton, NJ: Princeton University Press, 1993.

Hawley, Ellis W. The New Deal and the Problem of Monopoly: A Study in Economic Ambivalence. Princeton, NJ: Princeton University Press, 1966.

Haynes, Ada F. Poverty in Central Appalachia: Underdevelopment and Exploitation. New York: Garland Publishing, 1997.

Hessley, Rita K., John W. Reasoner, and John T. Riley. Coal Science: An Introduction to Chemistry, Technology, and Utilization. New York: John Wiley and Sons, 1986.

Hickam, Homer H., Jr. Rocket Boys: A Memoir. New York: Delacorte, 1998. . The Coalwood Way. New York: Delacorte, 2000. 
High, Stephen. Industrial Sunset: The Making of North America's Rust Belt, 1969-1984. Toronto: University of Toronto Press, 2003.

Himmelberg, Robert F. The Origins of the National Recovery Administration: Business, Government, and the Trade Association Issue, 1921-1933. New York: Fordham University Press, 1976.

. Survival of Corporatism During the New Deal Ear, 1933-1945.

Business and Government in America since 1870. New York: Garland Publishing, 1994.

Hodges, James A. New Deal Labor Policy and the Southern Cotton Textile Industry, 1933-1941. Knoxville: University of Tennessee Press, 1986.

Hourwich, Isaac. Immigration and Labor: The Economic Aspects of European Immigration to the United States. New York: B.W. Huebsch, 1922. Reprint, New York: AMS Press, 1972.

Irons, Janet. Testing the New Deal: The General Textile Strike of 1934 in the American South. Urbana: University of Illinois Press, 2000.

Jefferson, Thomas. Notes on the State of Virginia. Edited by William Pedan. Chapel Hill: University of North Carolina Press, 1954.

Johnson, Hugh S. The Blue Eagle from Egg to Earth. New York: Doubleday, 1935. Reprint, New York: Greenwood, 1968.

Johnson, James P. The Politics of Soft Coal: The Bituminous Industry from World War I through the New Deal. Urbana: University of Illinois Press, 1979.

Jones, Jacqueline. The Dispossessed: America's Underclass from the Civil War to the Present. New York: Basic Books, 1992.

Killian, Lewis M. White Southerners. New York: Random House, 1970.

Kuttner, Robert. The End of Laissez-Faire: National Purpose and the Global Economy After the Cold War. New York: Alfred A. Knopf, 1991.

Lake View Newcomer Committee. Summary of Visits to Southern White Families. Chicago: Lake View Newcomer Committee, 1961.

Lambie, Joseph. From Mine to Market: The History of Coal Transportation on the Norfolk and Western Railroad. New York: New York University Press, 1954. 
Lane, Winthrop D. Civil War in West Virginia. New York: Arno Press, 1969.

Laslett, John M. Labor and the Left: A Study of Socialist and Radical Influence in the American Labor Movement, 1881-1924. New York: Basic Books, 1970.

Lawall, C.E., I.A. Given, and H.G. Kennedy. Mining Methods in West Virginia. Morgantown: West Virginia University, 1929.

Laxer, Robert M., ed. (Canada) Ltd. The Political Economy of Dependency. Toronto: McClelland and Steward, 1973.

Lee, Howard B. Bloodletting in Appalachia: The Story of West Virginia's Four Major Mine Wars and Other Thrilling Incidents of Its Coal Fields. Morgantown: West Virginia University, 1969.

Leuchtenburg, William E. Franklin D. Roosevelt and the New Deal, 1932-1940. New York: Harper and Row, 1963.

Lewis, Helen, ed. Coal Productivity and Community: The Impact of the National Energy Plan in the Eastern Coalfields. Unpublished, 1978.

Lewis, Helen, Linda Johnson, and Don Askins, ed. Colonialism in Modern America: The Appalachian Case. Boone, NC: Appalachian Consortium Press, 1978.

Lewis, John L. The Miners' Fight for American Standards. Indianapolis: Bell Publishing, 1925.

Lewis, Ronald L. Black Coal Miners in America: Race, Class, and Community Conflict, 1780-1980. Lexington: University Press of Kentucky, 1987.

. Transforming the Appalachian Countryside: Railroads, Deforestation and Social Change in West Virginia, 1880-1920. Chapel Hill: University of North Carolina Press, 1998.

McCauley, Deborah Vansau. Appalachian Mountain Religion: A History. Urbana: University of Illinois Press, 1995.

MDC Panel on Rural Economic Development. Shadows in the Sunbelt: Developing the Rural South in an Era of Economic Change. Chapel Hill, NC: MDC, 1986. 
Mitchell, John. Organized Labor. Philadelphia: American Book and Bible House, 1903.

Monkkonen, Eric H. America Becomes Urban: The Development of United States Cities and Towns. Berkeley: University of California Press, 1988.

Morre, L.H. The History of the Southern Baptists in Ohio. Columbus: State Convention of Baptists in Ohio, 1979.

Mulcahy, Richard P. A Social Contract for the Coal Fields: The Rise and Fall of the United Mine Workers of America Welfare and Retirement Fund. Knoxville: University of Tennessee Press, 2000.

Murray, Charles. Losing Ground: American Social Policy 1950-1980. New York: Basic Books, 1984.

Obermiller, Phillip J. and William W. Philliber, ed. Appalachia in an International Context: Cross-National Comparisons of Developing Regions. Westport, CT: Praeger, 1994.

Northrup, Herbert R. Organized Labor and the Negro. New York: Harper and Brothers Publishers, 1944.

Obermiller, Phillip J., Thomas E. Wagner, and E. Bruce Tucker, ed. Appalachian Odyssey: Historical Perspectives on the Great Migration. Westport, CT: Praeger, 2000.

Patterson, James T. The New Deal and the States: Federalism in Transition. Princeton, NJ: Princeton University Press.

Peters, J.T. and H.B. Carden. History of Fayette County, West Virginia. Fayetteville, WV: Fayette County Historical Society, 1926.

Peterson, Bill. Coaltown Revisited: An Appalachian Notebook. Chicago: Henry Regnery Company, 1972.

Peterson, Gene B. and Laura M. Sharp. Southern Migrants to Cleveland. Washington: Bureau of Social Science Research, 1969.

Phelan, Craig. Divided Loyalties: The Public and Private Life of Labor Leader John Mitchell. Albany: State University of New York Press, 1994.

Philliber, William W. and Clyde B. McCoy, ed. The Invisible Minority: Urban Appalachians. Lexington: University Press of Kentucky, 1981. 
Photiadis, John. Selected Social and Sociopsychological Characteristics of West Virginians in their Own State and in Cleveland, Ohio. Morgantown: West Virginia University Appalachian Center, 1970.

Photiadis, John D., ed. Religion in Appalachia. Morgantown: West Virginia University Press, 1978.

Porter, Kathryn H. Poverty in Rural America: A National Overview. Washington: Center on Budget and Policy Priorities, 1988.

Proceedings of the West Virginia Coal Mining Institute, Twenty-Seventh Annual Meeting, Bluefield, West Virginia, December 5-6, 1933. Morgantown, 1933.

Pudup, Mary Beth, Dwight Billings, and Altina Waller, ed. Appalachia in the Making: The Mountain South in the Nineteenth Century. Chapel Hill: University of North Carolina Press, 1995.

Pursell, Donald E. and Gilbert L. Rutman. Selected Demographic Aspects of the West Virginia Economy, 1950-1975. Morgantown: West Virginia University Bureau of Business Research, 1969.

Report of the 1986 Commission on the Future of the South. Halfway Home and a Long Way to Go. Durham, NC: Southern Growth Policies Board, 1986.

Rice, Otis K. and Stephen W. Brown. West Virginia: A History, $2^{\text {nd }}$ Edition. Lexington: University Press of Kentucky, 1994.

Rosenfeld, Stuart A., Edward M. Bergman, and Sarah Rubin. After the Factories: Changing Employment Patterns in the Rural South. Durham, NC: Southern Growth Policies Board, 1985.

Ross, Malcolm. Machine Age in the Hills. New York: Macmillan Company, 1933.

Rothblatt, D.N. Regional Planning: The Appalachian Experience. Lexington, MA: Heath Lexington Books, 1971.

Rucker, Maude A., ed. West Virginia: Her Land, Her People, Her Traditions, Her Resources. New York: Walter Neale, 1930.

Salstrom, Paul. Appalachia's Path to Dependency: Rethinking a Region's Economic History. Lexington: University Press of Kentucky, 1994. 
Savage, Lon. Thunder in the Mountains: The West Virginia Mine War, 1920-21. Pittsburgh: University of Pittsburgh Press, 1990.

Schumpeter, Joseph. Capitalism, Socialism, and Democracy. New York: Harper and Row, 1942.

Schust, Alex P. Gary Hollow: A History of the Largest Coal Mining Operation in the World. Harwood, MD: Two Mule Publishing, 2005.

Schwartzeweller, Harry K., James S. Brown, and J.J. Mangalam. Mountain Families in Transition: A Case Study of Appalachian Migration. University Park: Pennsylvania State University Press, 1971.

Seltzer, Curtis. Fire in the Hole: Miners and Managers in the American Coal Industry. Lexington: University Press of Kentucky, 1985.

Shackelford, Laurel and Bill Weinberg. Our Appalachia: An Oral History. New York: Hill and Wang, 1977.

Shapiro, Henry D. Appalachia on Our Mind: The Southern Mountains and Mountaineers in the American Consciousness, 1870-1920. Chapel Hill: University of North Carolina Press, 1978).

Shifflett, Crandall A. Coal Towns: Life, Work, and Culture in Company Towns of Southern Appalachia, 1880-1960. Knoxville: University of Tennessee Press, 1991.

Shurick, Adam. The Coal Industry. Boston: Little, Brown, and Company, 1924.

Smith, Barbara E. Digging our Own Graves: Coal Miners and the Struggle over Black Lung Disease. Philadelphia: Temple University Press, 1987.

Smith, Janet, David Ostendorf, and Mike Schechtman. Who's Mining the Farm? Rochester: Illinois South Project, 1978.

Southeast Women's Employment Coalition. Women of the Rural South: Economic Status and Prospects. Lexington, KY: Southeast Women's Employment Coalition, 1986.

Spence, Robert Y. The Land of the Guyandot: A History of Logan County. Detroit: Harlo Press, 1976.

Spero, Sterling and Abram Harris. The Black Worker: The Negro and the Labor Movement. New York: Columbia University Press, 1931. 
Tams, W.P. The Smokeless Coal Fields of West Virginia: A Brief History. Morgantown: West Virginia University Library, 1963.

Teaford, Jon C. Cities of the Heartland: The Rise and Fall of the Industrial Midwest. Bloomington: Indiana University Press, 1993.

Thomas, Jerry B. An Appalachian New Deal: West Virginia in the Great Depression. Lexington: University Press of Kentucky, 1998.

Thompson, James Howard. Markets and Marketing Methods of the West Virginia Coal Industry. Morgantown: West Virginia University Bureau of Business Research, 1953.

. Significant Trends in the West Virginia Coal Industry, 1900-1957. Morgantown: West Virginia University Bureau of Business Research, 1958.

. The Changing Markets for West Virginia Coal, 1951-1963.

Morgantown: West Virginia University Bureau of Business Research, 1964.

Thurmond, Walter. The Logan Coal Field of West Virginia. Morgantown: West Virginia University Library, 1964.

Thurow, Lester. The Zero-Sum Society. New York: Basic Books, 1980.

Trotter, Joe William. Coal, Class, and Color: Blacks in Southern West Virginia, 1915-1932. Urbana: University of Illinois Press, 1990.

Tugwell, Rexford Guy. Industry's Coming of Age. New York: Columbia University Press, 1927.

Turner, William H. and Edward J. Cabbell, ed. Blacks in Appalachia. Lexington: University Press of Kentucky, 1985.

United Mine Workers of America. Proceedings, 1927 Convention. (Indianapolis: Cornelius Printing Company, 1927.

United Mine Workers of America, Nationalization Research Committee. How to Run Coal. Washington: United Mine Workers of America, 1922.

Vittoz, Stanley. New Deal Labor Policy and the American Economy. Chapel Hill: University of North Carolina Press, 1987. 
Wagner, Thomas E. and Phillip J. Obermiller. African American Miners and Migrants: The Eastern Kentucky Social Club. Urbana: University of Illinois Press, 2004.

Waller, Altina. Feud: Hatfields, McCoys, and Social Change in Appalachia, 1860-1900. Chapel Hill: University of North Carolina Press, 1988.

Walls, David S. and John B. Stephenson. Appalachia in the Sixties: Decade of Reawakening. Lexington: University Press of Kentucky, 1972.

Weller, Jack. Yesterday's People: Life in Contemporary Appalachia. Lexington: University of Kentucky Press, 1965.

West Virginia Coal Association. Coal Facts, 1986. Charleston: West Virginia Coal Association, 1986.

. Coal Facts, 1998. Charleston: West Virginia Coal Association, 1998.

Whisnant, David. All that is Native and Fine: The Politics of Culture in an American Region. Chapel Hill: University of North Carolina Press, 1983. . Modernizing the Mountaineer. New York: Burt Franklin, 1980.

White, Richard. The Roots of Dependency: Subsistence, Environment, and Social Change Among the Choctaws, Pawnees, and Navajos. Lincoln: University of Nebraska Press, 1983.

Williams, John A. West Virginia: A Bicentennial History. New York: W.W. Norton and Company, 1976.

. West Virginia and the Captains of Industry. Morgantown:

West Virginia University Library, 1976.

Williamson, J.W., ed. An Appalachian Symposium. Boone, NC: Appalachian State University Press, 1977.

Williamson, J.W. and Edwin T. Arnold, ed. Interviewing Appalachia: The Appalachian Journal Interviews, 1978-1992. Knoxville: University of Tennessee Press, 1994.

Zieger, Robert H. John L. Lewis: Labor Leader. Boston: Twayne Publishers, 1988. 


\section{Articles}

Alexander, J. Trent. "Defining the Diaspora: Appalachians in the Great Migration." Journal of Interdisciplinary History 37, 2 (Autumn 2006), 219-247.

Arthur, S.G. "How the War Ran over Elkton." Nation's Business (October 1945): 29.

Bailey, Kenneth. "A Judicious Mixture: Negroes and Immigrants in the West Virginia Mines, 1880-1917." West Virginia History 34 (January 1973): 141-161.

Ball, Richard. "A Poverty Case: The Analgesic Subculture of the Southern Appalachians.” American Sociological Review 33 (1968): 885-895.

Banks, Alan, Dwight Billings, and Karen Tice. "Appalachian Studies, Resistance, and Postmodernism." In Fighting Back in Appalachia: Traditions of Resistance and Change. Stephen L. Fisher, ed. Philadelphia: Temple University Press, 1993.

Banks, Alan, Stephen Fisher, Jim Foster, and Doug Gamble, ed. "Essays in Political Economy: Towards a Class Analysis of Appalachia." Appalachian Journal 11 (1984): 19.

Beury, William. "The Social Aspects of Coal Mines." In Proceedings of the West Virginia Coal Mining Institute, Twenty-Seventh Annual Meeting, Bluefield, West Virginia, December 5-6, 1933. Morgantown, 1933: 63-77.

Billings, Dwight, Mary Beth Pudup, and Altina Waller. "Taking Exception with Exceptionalism: New Approaches to the Social History of Early Appalachia." In Appalachia in the Making: The Mountain South in the Nineteenth Century. Mery Beth Pudup, Dwight Billings, and Altina Waller, ed. Chapel Hill: University of North Carolina Press, 1995.

Cantrell, Betty, Grace Phillips, and Helen Reed. "Widen, the Town J.G. Bradley Built." Goldenseal 3 (January 1977): 2-6.

Carter, Alice. "Segregation and Integration in the Appalachian Coalfields: McDowell County Responds to the Brown Decision." West Virginia History 54 (1995): 78-104.

Carter, Charles. "The West Virginia Coal Insurrection." North American Review 198 (October 1913): 457-469. 
Cattell-Gordon, David. "The Appalachian Inheritance: A Culturally Transmitted Traumatic Stress Syndrome.” Journal of Progressive Human Services 1 (1990): 41-57.

Collins, Justin. "My Experiences in the Smokeless Coal Fields of West Virginia." In West Virginia: Her Land, Her People, Her Traditions, Her Resources, ed. Maude A. Rucker. New York: Walter Neale, 1930.

“Comparing Appalachia's Counties with the Nation's." Appalachia 19, 2-4 (Spring 1986): 8-10.

Cubby, Edwin A. "Timbering Operations in the Tug and Guyandot Valleys in the 1890's." West Virginia History 26 (1965): 110-120.

Derickson, Alan. "From Company Doctors to Union Hospitals: The First Democratic Health-Care Experiments of the United Mine Workers of America." Labor History 33 (Summer 1992): 325-342.

. "Part of the Yellow Dog: U.S. Coal Miner Opposition to the Company Doctor System.” International Journal of Health Services 19, no. 4 (Fall 1989): 709-720.

DeStefano, Johanna S. 'Reading,' Writin,' and Route 23: A Road to Economic but not Educational Success." In From Mountain to Metropolis: Appalachian Migrants in American Cities. Kathryn M. Borman and Phillip J. Obermiller, ed. Westport, CT: Bergin and Garvey, 1994.

Dorner, Peter. "Fourteen Million Rural Poor." The Yale Review 68 (1969): 282292.

Ernst, Daniel. "The Yellow-Dog Contract and Liberal Reform, 1917-1932." Labor History 37 (Summer 1995): 426-456.

Fisher, Stephen. "Victim-Blaming in Appalachia: Cultural Theories and the Southern Mountaineer." In Appalachia: Social Context Past and Present. Bruce Ergood and Bruce Kuhre, ed. Dubuque, IA: Kendall Hunt, 1976.

Ford, Thomas. "The Passing of Provincialism." In The Southern Appalachian Region: A Survey. Thomas Ford, ed. Lexington: University of Kentucky Press.

Frost, William Goddell. "Our Contemporary Ancestors in the Southern Mountains.” Atlantic Monthly 83 (March 1899): 311-319. 
Gaventa, John. "Land Ownership and Productivity." In Coal Productivity and Community: The Impact of the National Energy Plan in the Eastern Coalfields. Helen Lewis, ed. Unpublished, 1978.

. "Property, Coal, and Theft." In Colonialism in Modern America: The Appalachian Case. Helen Lewis, Linda Johnson, and Don Askins, ed. Boone, NC: Appalachian Consortium Press, 1978.

Glen, John M. "The War on Poverty in Appalachia: A Preliminary Report." Register of the Kentucky Historical Society 87 (1989): 40-57.

Gompers, Samuel. "Russianized West Virginia." American Federationist 20 (October 1913): 825-835.

Goodrich, Carter. "Machine and the Miner." Harper's 154 (April 1927): 649-654. 91-93. . "Nothing but a Coal Factory." New Republic 44 (September 1925):

Harney, Will Wallace. “A Strange Land and Peculiar People.” Lippincott's Magazine 12 (October 1873): 429-438.

Higgins, S.C. "The New River Coal Fields." West Virginia Review (October 1927): 26-28.

Hutchinson, John. "John L. Lewis: To the Presidency of the UMWA." Labor History 19 (Spring 1978): 185-203.

Johnson, James P. "Drafting the NRA Code of Fair Competition in the Bituminous Coal Industry." Journal of American History LII (December 1966): 521-541.

Kissling, O.E. "Coal Mining in the South." Annals of the American Academy of Political and Social Science 153 (January 1931): 84-93.

Laing, James T. "The Negro Miner in West Virginia." In Blacks in Appalachia, ed. William H. Turner and Edward J. Cabbell. Lexington: University Press of Kentucky, 1985.

Lane, Winthrop D. "Black Avalanche.” Survey 47 (25 March 1922): 1044.

Lewis, Helen. "Fatalism or the Coal Industry?" In Appalachia: Social Context Past and Present. Bruce Ergood and Bruce Kuhre, ed. Dubuque, IA: Kendall Hunt, 1976. 
Lewis, Helen, Sue Kobak, and Linda Johnson. "Family, Religion, and Colonialism in Central Appalachia: Or, Bury My Rifle at Big Stone Gap." In Growing up Country. Jim Axelrod, ed. Clintwood, VA: Council of the Southern Mountains, 1973.

Longin, Thomas. "Coal, Congress, and the Courts: The Bituminous Coal Industry and the New Deal." West Virginia History 34 (January 1974): 101-130.

Maloney, M. and B. Huelsman. "Humanism, Scientism, and Southern Mountaineers." People's Appalachia 2 (1972): 24-27.

Maxwell, James A. "Down from the Hills and into the Slums." Reporter 15 (13 December 1956): 27-28.

McCoy, Clyde B. and James S. Brown. "Appalachian Migration to Midwestern Cities." In The Invisible Minority: Urban Appalachians. William W. Philliber and Clyde B. McCoy, ed. Lexington: University Press of Kentucky, 1981.

Miernyk, W.H. "Coal and the Future of the Appalachian Economy." Appalachia 9, 2 (1975): 29-35.

Nagle, W.J. “Appalachia Fights for Jobs in a Recession.” Appalachia 15, 5 (1982): 1-9.

Northrup, Herbert R. “The Coal Mines.” In Blacks in Appalachia, ed. William H. Turner and Edward J. Cabbell. Lexington: University Press of Kentucky, 1985.

Olson, James S. "The Depths of the Great Depression: Economic Collapse in West Virginia, 1932-1933.” West Virginia History 38 (April 1977): 214-225.

Olson, Mancur. "Rapid Growth as a Destabilizing Force." Journal of Economic History 23 (December 1963): 529-552.

O'Toole, Edward. "Pocahontas Coal Field and Operating Methods of the United States Coal and Coke Company." Coal Age 23 (8 March 1923): 399-407.

Parsons, Floyd. "Coal Mining in Southern West Virginia." Engineering and Mining Journal (9 November 1907): 881-884.

Photiadis, John D. "Occupational Adjustment in Cleveland." In The Invisible Minority: Urban Appalachians. William W. Philliber and Clyde B. McCoy, ed. Lexington: University Press of Kentucky, 1981. 
Portes, A. "On the Sociology of National Development: Theories and Issues." American Journal of Sociology 82 (1976): 55-85.

Sawhill, Isabell V. "Poverty in the U.S.: Why Is It So Persistent?" Journal of Economic Literature 26 (September 1988): 1086-1092.

Stewart, Shirley L. and Connie L. Rice. "The 'Birds of Passage' Phenomenon in West Virginia's Out-Migration." In Appalachian Oddyssey: Historical Perspectives on the Great Migration. Phillip J. Obermiller, Thomas E. Wagner, and E. Bruce Tucker, ed. Westport, CT: Praeger, 2000.

Tice, Karen and Dwight Billings. “Appalachian Culture and Resistance.” Journal of Progressive Human Services 2 (1991): 1-18.

Tickamyer, Ann R. and Cynthia M. Duncan. "Poverty and Occupational Structure in Rural America." Annual Review of Sociology 16 (1990): 67-86.

Votaw, Albert N. “The Hillbillies Invade Chicago.” Harper's 216 (February 1956): 64-67.

Walls, David S. "Central Appalachia: A Peripheral Region within an Advanced Capitalist Society." Journal of Sociology and Social Welfare 4 (1976): 233.

. "On the Naming of Appalachia." In An Appalachian Symposium, ed. J.W. Williamson. Boone, NC: Appalachian State University Press, 1977.

Weiner, Deborah. "From Modern Victory to Postmodern Defeat: Two Baltimore Housing Projects." The Maryland Historian 26, no 2 (Fall/Winter 1995): 23-48.

Workman, Michael E. “The Kay Moor Mine, 1901-1962: A Case Study of Underground Mechanization in the Bituminous Coal Fields of Southern West Virginia." Canal History and Technology Proceedings 19 (2000): 143-179.

Yarrow, Mike. "Voices from the Coalfields: How Miners' Families Understand the Crisis of Coal." In Communities in Economic Crisis: Appalachia and the South. John Gaventa, Barbara Ellen Smith, and Alex Willingham, ed. Philadelphia: Temple University Press, 1990.

\section{Theses and Dissertations}

Brown, James S. "The Social Organization of an Isolated Kentucky Mountain Neighborhood.” Ph.D. Dissertation, Harvard University, 1950. 
Everling, Arthur C. "Tactics Over Strategy in the United Mine Workers of America." Ph.D. Dissertation, Pennsylvania State University, 1976.

Gowaskie, Joseph M. “John Mitchell: A Study in Leadership.” Ph.D. Dissertation, Catholic University of America, 1968.

Lilly, Everett A. "Leaving Clear Fork Valley: A Story of Appalachian Migration." Ph.D. Dissertation, Brandeis University, 1997.

Mirvis, Kenneth. "A Phenomenological Analysis of Two Appalachian Coal Producing Counties.” Ed.D. Dissertation, Boston University, 1981.

Myers, Mark S. "Mechanization and Migration from McDowell County, West Virginia, 1932-1970.” M.A. Thesis, East Tennessee State University, 2001.

Salter, Kay. "Interstate 77, The Hillbilly Highway?: A Case Study of Migration from McDowell County, West Virginia to the North Carolina Piedmont." M.A. Thesis, Appalachian State University, 1997.

Simon, Richard Mark. "The Development of Underdevelopment: The Coal Industry and Its Effect on the West Virginia Economy, 1880-1930.” Ph.D. Dissertation, University of Pittsburgh, 1978.

Smith, Thaddeus. "Where there are No Mountains: Appalachian Culture and Migration to Baltimore." Ph.D. Dissertation, Brown University, 1987.

Thomas, Jerry Bruce. "Coal Country: The Rise of the Southern Smokeless Coal Industry and its Effect on Area Development, 1872-1910." Ph.D. Dissertation, University of North Carolina, 1971.

Wade, Howard F. "Black Gold and Black Folk: A Case Study of McDowell County, West Virginia's Black Migrants, 1890-1940.” D.A. Dissertation, University of Miami, 1990.

Wilson, Steven Douglas. "The Adjustment Process of Southern Appalachian Whites in Cincinnati, 1940-1979.” Ph.D. Dissertation, University of Kentucky, 1983.

Worley, William David. "Social Characteristics and Participation Patterns of Rural Migrants in an Industrial Community." M.A. Thesis, Miami University, 1961. 